\title{
Kenyan Exports of Nile Perch: The Impact of Food Safety Standards on an Export-Oriented Supply Chain
}

\author{
Spencer Henson and Winnie Mitullah ${ }^{1}$
}

Contacts: shenson@uoguelph.ca;wvmitullah@swiftkenya.com

\begin{abstract}
Over the past decade, exports of fish and fishery products from developing countries have increased rapidly. However, one of the major challenges facing developing countries in seeking to maintain and expand their share of global markets is stricter food safety requirements in industrialized countries. Kenyan exports of Nile perch to the European Union provide a notable example of efforts to comply with such requirements, overlaid with the necessity to overcome restrictions on trade relating to immediate food safety concerns. Although food safety requirements were evolving in their major markets, most notably the European Union, most Kenyan exporters had made little attempts to upgrade their hygiene standards. Likewise, the legislative framework of food safety controls and facilities at landing sites remained largely unchanged. Both exporters and the Kenyan government were forced to take action when a series of restrictions were applied to exports by the European Union over the period 1997 to 2000. Processors responded by upgrading their hygiene controls, although a number of facilities closed, reflecting significant costs of compliance within the context of excess capacity in the sector. Remaining facilities upgraded their hygiene controls and made efforts to diversify their export base away from the European. Legislation and control mechanisms were also enhanced. Hygiene facilities at landing beaches were improved, but remain the major area of weakness. The Kenyan case illustrates the significant impact that stricter food safety requirements can have on export-oriented supply chains. It also demonstrates how such requirements can exacerbate existing pressures for restructuring and reform, while prevailing supply and capacity issues constrain the manner in which the supply chain is able to respond. In Kenya most of the concerted effort to comply with these requirements was stimulated by the sudden loss of market access in very much a 'crisis management' mode of operation, illustrating the importance of responding to emerging food safety requirements in a proactive and effective manner.
\end{abstract}

\section{Keywords: SPS standards; capacity-building; compliance costs; fish trade}

World Bank Policy Research Working Paper 3349, June 2004

The Policy Research Working Paper Series disseminates the findings of work in progress to encourage the exchange of ideas about development issues. An objective of the series is to get the findings out quickly, even if the presentations are less than fully polished. The papers carry the names of the authors and should be cited accordingly. The findings, interpretations, and conclusions expressed in this paper are entirely those of the authors. They do not necessarily represent the view of the World Bank, its Executive Directors, or the countries they represent. Policy Research Working Papers are available online at http:/lecon.worldbank.org.

\footnotetext{
${ }^{1}$ Spencer Henson is in the Department of Agricultural Economics and Business, University of Guelph, Canada. Winnie Mitullah is in the Institute for Development Studies, University of Nairobi, Kenya.
} 


\section{INTRODUCTION}

Exports of fish and fishery products are widely seen as a developing country success story and a welcome contrast to the cyclical decline in markets for many traditional commodities. Over the last decade, developing country exports of fish and fishery products have increased at an average rate of 6 percent per annum. Further, developing countries en masse now account for the majority of world exports, for which the predominant markets are in industrial countries.

One of the major challenges facing developing country exports of fish and fishery products is progressively stet strict food safety requirements, particularly in major markets such as the European Union (EU) and United States of America (USA). Previous studies suggest that exporters in a number of developing countries have experienced problems complying with these requirements (see for example Henson et al., 2000; Rahman, 2001; Musonda and Mbowe, 2001; UNEP, 2001a; 2001b; Zaramba, 2002) ${ }^{2}$. However, although the associated costs of compliance can be high (see for example Cato, 1998; Cato and Lima dos Santos, 1998a; 1998b), the returns in terms of continued and/or expanded access to high-value markets can be considerable. Further, in many countries the necessary investment in up grading supply chain and regulatory systems has not been made in line with the expansion of exports and is arguably long overdue.

This study focuses on fish and fishery products from Kenya, in particular Nile perch (Lates Niloticus) from the inland fishery of Lake Victoria. The specific aims of the study are as follows:

- To identify the food safety and other standards faced by suppliers of Nile perch in their major export markets, both relating to regulatory and customer requirements.

- To assess the impact of food safety and other standards on the level and direction of exports of Nile perch.

- To identify and assess the strategies that both the government and exporters of Nile perch have adopted in order to comply with food safety and other market requirements.

- To identify and quantify the costs incurred by the government and exporters of Nile perch producers in complying with food safety and other standards in major export markets.

- To identify the constraints that impede compliance with food safety and other standards in major export markets for Nile perch.

- To identify areas where technical or other assistance might facilitate compliance with food safety and other requirements in major export markets for Nile perch.

The case of Nile perch exports from Kenya provides an example of longer-term efforts to comply with food safety requirements in export markets, overlaid with the necessity to overcome restrictions on trade relating to immediate food safety concerns. On the one hand, both the government and exporters have been required to comply with stricter food safety requirements in their most important export markets, namely the EU. On the other, exporters of Nile perch in Kenya (as well as Tanzania and Uganda) faced periodic restrictions on trade with the EU over the period 1997 to 2000 because of concerns relating to controls on hygiene and pesticide residues. Although efforts have been made to enhance food safety capacity within both the

${ }^{2}$ A more general literature exists on the impact of food safety and other sanitary and phytosanitary (SPS) measures on developing country exports of agricultural and food products (see for example FAO, 1999; Henson et al, 1999; Bankole et al., 2000; Jha, 2002). 
public and private sectors, exporters have also sought to penetrate new export markets where food safety requirements are less of an impediment and otherwise to diversify their export base.

A key element of this case is the inter-dependency of the various levels of the supply chain and of the public and private sectors in meeting food safety requirements in export markets. Thus, efforts have been required at both landing beaches and in industrial processing plants in order to achieve compliance. Further, reform and capacity-building have also been required within public sector institutions responsible for ensuring compliance with export market requirements. The need for coordination between institutions and economic agents involved is a key theme. Further, the experiences of the Nile perch fisheries illustrate the 'public good' elements of compliance with food safety and other SPS requirements in export markets, which are dependent on the collective actions of actors at all levels of the supply chain and within public institutions.

Although industrialized countries as a whole are enhancing food safety controls applied to both domestically-produced and imported agricultural commodities and food products, this case illustrates the distinct ways in which quantitatively and qualitatively different standards and conformity assessment procedures affect trade. In particular, it illustrates how controls based on prior inspection and approval of export facilities can have a markedly greater effect on the ability of developing countries to access export markets than border inspection regimes.

The paper is structured as follows. To provide the broader context and importance of the case, the role of developing countries in global fish and fishery products trade is discussed. The remainder of the paper then focuses on Kenyan exports of fish and fishery products and the structure and modus operandi of the Nile perch export supply chain. It looks first at the historical evolution of the Nile perch fishery, supply chain and regulatory environment. The economic importance of the Nile perch sector at both the micro and macro-economic levels and Kenya's export performance prior to the mid-1990s are then described. At that time neither the government of Kenya nor the fish processing sector had made any significant attempts to upgrade food safety requirements despite the progressive export orientation of the Nile perch fishery. Having laid down the historical and socio-economic context, the impact of the EU's food safety controls on fish imports is then examined. The analysis covers the strategies adopted by both the government of Kenya and participants at each level of the supply chain in order to achieve compliance, and the associated costs. A distinction is made between broad efforts to comply with evolving food safety standards and the effects of direct restrictions on exports to the EU.

\section{DEVELOPING COUNTRIES AND GLOBAL TRADE IN FISH AND FISHERY PRODUCTS}

Over the period 1996-2001 global fish production increased from 120.2 million tonnes to 128.8 million tonnes, at an annual average growth rate of around 1.5 percent. Global fish production is dominated by marine capture which accounted for 64 percent in 2001 . However, the importance of marine capture fisheries is in decline, reflecting growth in inland and marine aquaculture and, to a lesser extent, inland capture fisheries. Global production is dominated by China which accounted for 35 percent in 2001. 
Inland capture fisheries accounted for 6.8 percent of total fisheries production in 2001. Predominantly, inland capture fisheries are found in developing countries; China accounted for 25.4 percent of production in 2000, whilst other developing countries collectively accounted for 67.4 percent $^{3}$. These included India, Bangladesh, Uganda and Indonesia (Figure 1). Kenya accounted for 2.4 percent of global inland capture fishery production in 2000.

Figure 1. Major inland capture fisheries producers, 2000:

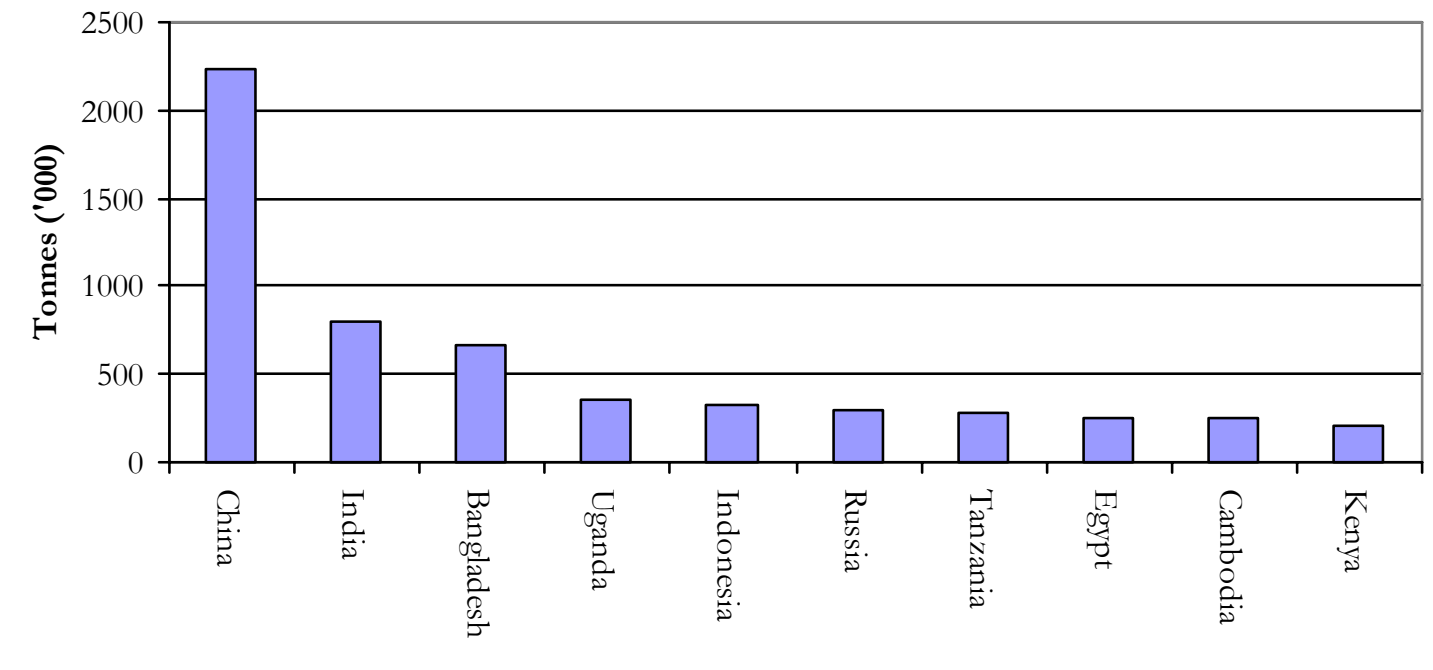

Source: FAO (2002).

Global demand for fish and fishery products has increased rapidly over the last 50 years from around 39 million tonnes (live weight equivalent) in 1961 to approaching 130 million tonnes in 2000 (FAO, 2002). Human consumption of fish increased from 27 million tonnes (live weight equivalent) in 1961 to 95.5 million tonnes in $1999^{4}$. Over this period, the average annual growth rate in consumption (excluding China) was 2.4 percent, whilst population only increased at 1.8 percent per annum, suggesting a significant increase in per capita consumption.

Global trade in fish and fishery products was US $\$ 55.2$ billion in 2000 , having increased by 8 percent since 1998. This increase was largely due to a rise in the volume of commodities traded, since the price of the major products actually declined (FAO, 2002). Major exporters include Thailand (US\$4.4 billion) and China (US\$3.7 billion). Collectively, developing countries account for around 50 percent of world exports.

Industrialized countries account for around 80 percent of global imports of fish and fishery products (Figure 2). Thus, the predominant trade flows are from developing countries to industrialised countries and between industrialised countries. However, while developing country exports increased at an average rate of 8.1 percent per annum through the 1990s,

\footnotetext{
3 Actual production in developing countries is probably greater than these recorded data due to problems with the accurately monitoring levels of capture at numerous and scattered points of landing.

4 The balance is accounted for by the use of fish in production of animal feed.
} 
industrialised country imports only increased by 3.2 percent per annum, reflecting the increasing importance of intra-developing country trade in fish and fishery products.

Figure 2. World trade in fish and fishery products, 1993-2000:

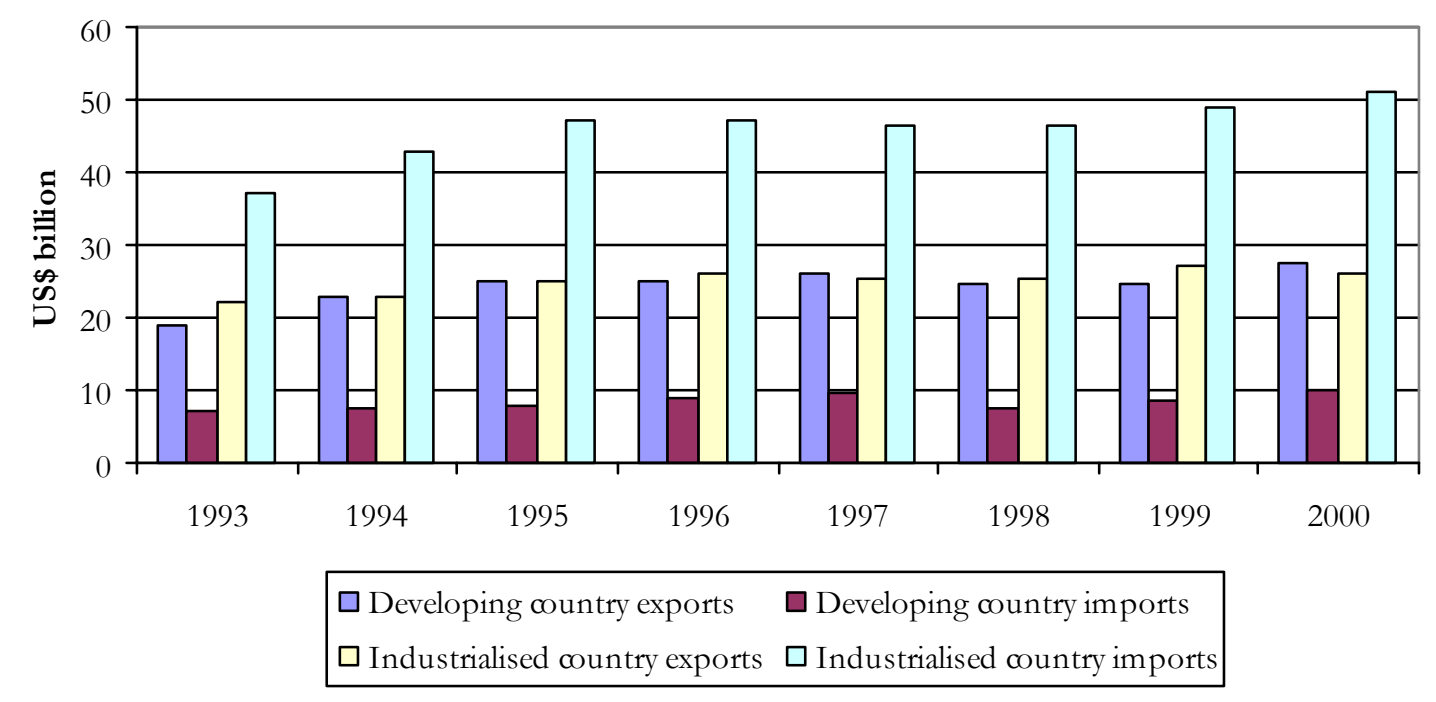

Source: FAO (2002).

Africa accounts for less than 5 percent of global fish and fishery product exports. However, the value of exports increased significantly following the mid-1970s and particularly through the $1990 \mathrm{~s}$. Thus, exports in 2000 exceeded US $\$ 2.5$ billion, compared with less than US $\$ 0.5$ billion in 1976.

Net receipts of developing countries from fish and fishery product exports increased significantly over the last two decades from US\$3.7 billion in 1980 to US\$18.0 billion in 2000 (FAO, 2003). This represents an increase of 250 percent in real terms. For many developing countries, exports of fish and fishery products are an important source of foreign currency earnings. Indeed, the aggregate value of net exports over the period 1980-2000 was greater than for many traditional commodity exports, including coffee, bananas, tea and rubber.

At the micro level, fish and fishery products are an important source of livelihood in rural areas of developing countries. It is estimated that 34.5 million people were directly engaged in fishing or fish farming as a full or part-time occupation in 2000 (FAO, 2003). This compares with 28 million in 1990, an increase of 25 percent. Of these, 85 percent are in Asia and seven percent in Africa.

The number of people directly engaged in fish production across Africa is estimated at around 2.6 million. The number increased significantly (35\%) during the $1990 \mathrm{~s}$, although remains a small fraction (1.4\%) of the population that is economically active in agriculture. In contrast to other developing regions, in particular Asia, a very small proportion $(2.3 \%)$ is engaged in fish farming, emphasising the dominance of capture, and in particular marine capture, fisheries. 
The foregoing discussion highlights the importance of fish production and trade to developing countries at both the level of the macro-economy and rural livelihoods. Although inland capture fisheries represent a relatively small sub-sector on a global scale, in many countries (for example Kenya, Tanzania and Uganda that border Lake Victoria) they represent a key element of the rural economy and/or account for a significant proportion of fish and fishery product exports.

Whilst developing countries have gained an increasing share of global trade in fish and fishery products and are predicted to dominate both global production and exports of fish in the future (Delgado et al., 2003a; 2003b), there is evidence that exporters are facing growing challenges meeting food safety requirements in industrialised countries. As a consequence, both developing country governments and private sector exporters increasingly have to make choices between exploiting the growing demand for fish amongst urban middle and high-income consumers in other developing countries and/or implementing the investments required to comply with these requirements ${ }^{5}$. In many cases this is occurring within the context of a lack of investment in the up-grading of regulatory institutions and supply chains despite the progressive export-orientation of fish and fishery products sectors. The Nile perch fisheries of Kenya provide a particularly good example of this.

\section{REGULATORY ENVIRONMENT FOR NILE PERCH EXPORTS}

As an export-oriented supply chain, the Nile perch fishery is subject to regulatory and customer requirements both domestically and in major export markets. The predominant requirements for fish and fishery products relate to food safety, in particular standards of hygiene in production and marketing and limits on levels of microbiological contamination in the end product. Further, limits are being applied on environmental contaminants, for example heavy metals and agrochemical residues. In some markets grades and quality standards are applied, although these are generally restricted to major fish species in world trade and this is not a significant issue for Nile perch.

As the main market for Kenyan exports until 1996, regulatory requirements within the EU have arguably been the most important drivers of food safety controls in the fish supply chain. Indeed, as will be seen, regulations relating to hygiene in the production and marketing of fish and fishery products in Kenya have, to all intents and purposes, been harmonised with those of the EU. However, attempts to access (or at least examine the potential to access) other markets have exposed Kenyan exporters of fish and fishery products to distinct food safety requirements and alternative forms of conformity assessment. Thus, this section describes, compares and contrasts the food safety requirements applied to Kenyan exports of Nile perch in the EU, Australia, Japan and USA.

\footnotetext{
${ }^{5}$ In the long term, however, the food safety requirements of developing countries will also become stricter and the upgrading of supply chains will not be a viable option. A major driver of this is the increasing role of supermarket chains in the retail food markets of developing countries (see for example Reardon and Berdegue, 2003; Weatherspoon and Reardon, 2003).
} 


\subsection{European Union}

The EU lays down harmonized requirements governing hygiene in the capture, processing, transportation and storage of fish and fishery products (Globefish, 2000). ${ }^{6}$ EU legislation lays down detailed requirements regarding the landing of fish, structure of wholesale and auction markets and processing facilities (for example construction of walls and floors, lighting, refrigeration, ventilation, staff hygiene etc.), processing operations, transportation, storage, packaging, checks on finished products (including visual, organoleptic, chemical and microbiological parameters), laboratories ${ }^{7}$ and water quality. More generally, it requires that fish processing facilities undertake 'own checks', broadly based on the principle of Hazard Analysis Critical Control Point (HACCP) ${ }^{8}$. Key elements of these requirements include:

- Identification of critical points in the processing establishment on the basis of the manufacturing process used.

- Establishment and implementation of methods for monitoring and checking such critical points.

- Taking samples for analysis in an approved laboratory for the purposes of checking, cleaning and disinfection methods and checking compliance with the standards established by the Directive.

- Keeping a written record of these controls for at least two years.

More specifically, 'own checks' refers to all actions aimed at ensuring and demonstrating compliance with standards laid down by EU legislation". This involves:

- Identification of hazards, analysis of risks necessary to control those risks.

- Identification of critical points.

- Establishment of critical limits for each control point.

- Establishment of a monitoring and checking procedures.

- Establishment of corrective action to be taken when necessary.

- Establishment of a verification and review procedures.

- Establishment of documentation concerning all procedures and records.

Processing plants are inspected and approved on an individual basis by a specified 'Competent Authority' in the country of origin, whether an EU Member State or a Third Country ${ }^{10}$, to ensure they comply with these requirements. The European Commission undertakes checks to ensure that the Competent Authority undertakes this task in a satisfactory manner and to ensure provisions of the Directive are complied with.

Imports from Third Countries are required to comply with requirements that are at least equivalent to those of the EU. Further, specific import conditions are established according to the particular health situation of that country, taking account of:

\footnotetext{
${ }^{6}$ Directive $91 / 493 /$ EEC.

${ }^{7}$ Reference is made to EN45001 standards, although lesser requirements are specified for laboratories internal to processing establishments.

${ }^{8} \mathrm{HACCP}$ is a system of process control based on the identification of 'critical control points' that affect the safety of the end product and the implementation of controls at each of these points. For further information see for example Mortimore and Wallace (2000).

${ }^{9}$ Directive 94/356/EC.

${ }^{10}$ Countries outside of the EU.
} 
- Legislation of the country.

- Organization of the competent authority and of inspection services, the powers of such services and the supervision to which they are subject, and their facilities for effectively verifying the implementation of legislation in force.

- Actual health conditions during the production, storage and transport of fish and fishery products.

- Assurance which the country can give on compliance with EU standards.

In most cases the Commission undertakes periodic inspections for the purposes of determining local health conditions and establishing specific import conditions for the country concerned. These typically include procedures for: obtaining a health certificate which must accompany all consignments exported to the EU, placing of a mark identifying the establishment from which a consignment is derived, and establishing a list of approved establishments and auction or wholesale markets that meet EU standards.

Only establishments approved by the Competent Authority are permitted to export to the EU. As noted above, these establishments must comply with requirements that are at least equivalent to those of the EU and be monitored by the inspection services of the exporting country. The Competent Authority provides the Commission with a list of approved establishments and this is subsequently published in the Official Journal of the European Communities.

Countries for which the European Commission has approved local requirements as being at least equivalent to those in the EU and for which specific import requirements have been established are subject to reduced physical inspection at the border (see below). These are published in Part I of the list of approved countries. Countries for which these procedures have not been completed but where assurances have been given that requirements are at least equivalent to those in the EU are permitted to export on an interim basis. Consignments must be accompanied by a health certification but are not subject to reduced physical checks at the border. These are published in Part II of the list of approved countries ${ }^{11}$.

Initially, the deadline for countries to achieve Part I status was 31 December 1996. However, this has been extended on four occasions and currently expires on 31 December $2005 .{ }^{12}$ This reflects both the difficulties that a number of countries have experienced complying with EU hygiene standards for fish and fishery products and also the considerable time and resources required for the Commission to undertake inspections in order to establish specific import requirements (see below).

Imports to the EU are also subject to a systematic programme of physical checks to ensure the product still complies with regulatory requirements as certified on the accompanying veterinary health certificate. ${ }^{1314}$ These must cover at least one percent of the items in a consignment from a

\footnotetext{
11 Until 31 January 1999 imports were permitted to individual EU Member States on a bilateral basis (Decision 98/419/EC). The Member State was responsible for ensuring imports were produced and marketed under conditions that were least as equivalent to those in the EU. These were included in Annex II to the list of approved countries.

12 Council Decision 2003/912/EC.

${ }^{13}$ Commission Decision 94/360/EC amended by 99/609/EC.
} 
minimum of two to a maximum of ten items. However, these checks can be less frequent under certain conditions, for example:

- Where products originate in a Third Country offering satisfactory health guarantees as regards checks at the point of origin.

- Where products come from establishments on a list drawn up in accordance with EU rules and/or undergone Community or national inspection.

- Import certificates have been issued for the products concerned.

All products can be subject to more extensive checks if there is evidence of potential violation of EU requirements and/or an immediate threat to animal or public health.

Where the Commission identifies zoonoses or other diseases liable to present a serious threat to animal or public health, especially in light of veterinary inspections or checks at the border, a variety of measures can be adopted ${ }^{15}$. For example:

- Suspension of imports from all or part of the country concerned and, where appropriate, the Third Country of transit.

- Establishment of special conditions in respect of products coming from all or part of the Third Country.

- Establishment of requirements for appropriate checks, which may include specifically looking for risks to public or animal health and increased frequency of physical checks.

It was under these provisions that the EU took specific action to restrict imports of Nile perch and other fish from Kenya, Tanzania and Uganda over the period 1997-2000 (see Section 6).

The European Commission has presented its controls on hygiene for imports of fish and fishery products as a practical example of the application of equivalence (WTO, 2002) ${ }^{16}$. Thus, rather than laying down specific requirements, the EU focuses on the conditions under which products will be equivalent to those produced in EU. The steps in this process include:

1. Documentary evaluation of a Third Country's legislation and inspection systems.

2. Inspection by the European Commission so that specific import conditions can be established taking account of local circumstances.

3. Establishment of procedures within the exporting country for issuing health certificates to accompany each consignment and for the approval of processing plants and wholesale and auction markets.

At each stage there is exchange of information between the EU and the Third Country authorities. Where this process identifies full equivalence, exports are permitted from all establishments approved by the Competent Authority. Where the systems in place in the Third Country are not equivalent for all products, exports are only permitted for certain products and/or from certain establishment.

\footnotetext{
${ }^{14}$ However, it is widely recognised (for example amongst importers) that different procedures and/or testing methods are employed at ports of entry between Member States. This has led to the phenomenon of 'port shopping' whereby importers focus on ports of entry that have, or at least are perceived to have, less strict procedures.

${ }_{15}$ Council Directive 92/894/EEC.

16 The equivalency provision of the Agreement on Sanitary and Phytosanitary Measures encourages WTO Members to recognise the SPS measures of other countries where they can be shown to provide the same level of protection.
} 
Under this system, the Competent Authority is responsible for continuous monitoring and management of the controls in place and for taking appropriate action as required (WTO, 2002). Examples include suspension of particular establishments if they are out of conformity or require improvement, of the suspension of exports. However, there is also the possibility that private laboratories or inspection services can be employed, or even the Competent Authority and inspection services of another country.

\subsection{Japan}

Imports of fish and fishery products to Japan must comply with the provisions of both the Food Sanitation Law and the Quarantine Law (Globefish, 1998; JETRO, 2003). These lay down general requirements that prohibit the import and sale of products that:

- Are rotten, decomposed, or immature such that they are unfit for human consumption.

- Contain or are suspected to contain toxic or injurious substances.

- Contaminated with or suspected to be contaminated with pathogenic microorganisms.

- May injure human health due to lack of cleanliness, addition of extraneous substances, or any other cause.

There are limited requirements that relate specifically to fish and fishery products. Imports require a health certificate from the relevant government agent in the country of origin that specifies the species and area of collection. Marine products from cholera-infected areas are subject to automatic border inspection. Maximum levels for microbiological contaminants are specified for frozen fish. For example, uncooked frozen fish must have a maximum plate count of 300,000/gram and zero coliforms, Salmonellae and Staphylococcus aureus.

All food imports require prior notification to Food Sanitation Inspectors at quarantine stations. However, a planned import system is in place for regular imports whereby a plan of consignments is submitted and prior-notification waived for a specified period of time. Inspectors undertake document examinations and inspection. Inspection is risk-based according to, for example, records of previous non-compliance. Further, some products are subject to monitoring inspection based on levels of imports and previous record of non-compliance. When a consignment is subject to inspection by a public agency in the exporting country and a report is provided, inspection at the Japanese border may be waived. In the case of frozen foods, the Japanese Frozen Foods Inspection Corporation (JFFIC) is authorised by the Ministry of Health, Labour and Welfare to undertake inspections.

\subsection{Australia}

Imports of fish and fishery products to Australia are subject to inspection and approval by the Australian Quality Inspection Service (AQIS). Clearance is provided on the basis of three alternative mechanisms:

- Inspection, sampling and analysis of consignments under the Imported Food Program (IFP).

- Acceptable inspection certification of food products under agreements with other countries.

- Quality Assurance Agreement between individual establishments in a Third Country and AQIS. 
Under the IFP, foods are classified according to the potential risk to human health based on the nature of the food and historical inspection data:

- Risk category foods: These are foods that have been deemed to represent the highest potential risk to human health. Currently, this category includes crustaceans, certain species of fish (for example tuna, shark and hake) and smoked fish. All consignments are referred to the IFP. The intensity of inspection applied to these foods depends on the compliance history of the manufacturer. Producers whose food products consistently comply with Australian requirements will be inspected at a less intensive rate than those with a poor compliance rate. All producers have their foods inspected at the initial rate of 100 percent of consignments. Usually, after five consecutive consignments have passed inspection, these foods are inspected at a less intense rate of one in four consignments on a random basis. Twenty passes must be achieved before the rate reduces to one in 20 on a random basis, providing imports continue at a steady rate.

- Active surveillance foods: These are identified for active surveillance in order to gather more information. Foods in this category have, through their previous inspection history, indicated that more intensive inspection is required to determine if the food should be risk-categorised or returned to the random surveillance level (see below). Foods in this group are inspected at a rate of approximately 10 percent by country-of-origin.

- Random surveillance: All other foods are subject to random surveillance. Foods in this category are inspected at a rate of 5 percent of shipments.

In general, Nile perch falls into the category of random surveillance, although active surveillance may be applied if specific problems are detected, for example through a number of consecutive consignments that do not comply with Australian food safety requirements.

Inspection certification arrangements have been established for very few countries. In the case of fish and fishery products, agreements currently exist with Canada, Malaysia, Philippines, Singapore and Thailand (for cooked and frozen crustaceans and fish products only).

A Quality Assurance Agreement is an arrangement between AQIS and a company in an exporting country that has implemented a quality assurance system which ensures that the product complies with the requirements of the Imported Food Control Act 1992 and Australian Food Standards Code. Imports from such companies are subject to lower levels of border inspection, subject to a legal minimum of five percent.

To establish a Quality Assurance Agreement an exporter needs to comply with all relevant elements of ISO 9001 or ISO 9002 and be accredited by a Third Party Accreditation Body approved by the Joint Accreditation System of Australia and New Zealand (JAS-ANZ). Further, they must implement a food safety program (based on the principle of HACCP) that is equivalent to that required for Australian processors.

Exporters must also comply with relevant Codes of Practice established by Codex Alimentarius. The entire system must be documented in a quality system manual which is reviewed by AQIS prior to approval. 


\subsection{United States}

The traditional strategy applied to imports of fish and fishery products to the United States was based on physical examination at the border. This was primarily directed towards substances that would cause the consignment to be adulterated under US law. However, whilst border inspection remains an integral element of US food safety controls, more recent rules require that importers be proactive in ensuring consignments comply with US regulatory requirements.

Processors of fish and fishery products are required to comply with general requirements relating to the structure of premises, equipment and product and process controls, which mandate the application of Good Manufacturing Practice (GMP) ${ }^{17}$. Further, as of December 1997, legislation governing the processing and importing of fish and fishery products requires that processors maintain Sanitation Standard Operating Procedures (SOP), including written sanitation records, and implement HACCP. ${ }^{18}$. Imports of fish and fishery products must comply with the same requirements. Further, US importers are required to take 'affirmative steps' to ensure this is the case.

Under this legislation, importers have a responsibility to verify that the fish and fishery products they are importing comply with US regulatory requirements. There are two main ways in which this can be achieved. Firstly, the product can be obtained from a country that has a Memorandum of Understanding (MOU) with the Us Food and Drugs Administration (FDA), which documents the equivalency or compliance of that country's inspection system for fish and fishery products with US requirements. In such cases the importer's responsibilities are automatically fulfilled. Currently Canada, Chile, South Korea, Australia, New Zealand, Norway, China, Thailand Japan, Iceland and the EU have agreed or are negotiating an MOU with the FDA.

Alternatively, the importer can have written verification procedures for ensuring that imported fish and fishery products have been processed in accordance with US regulatory requirements. There are two components to this. Firstly, product specifications designed to ensure that the product is not adulterated, as defined by US legislation. Secondly, 'affirmative steps' to verify that the product has been processed in accordance with US regulatory requirements. The steps that an importer must take are not mandated, but examples include:

- Obtaining HACCP and sanitation monitoring records from the foreign processor to ensure US regulatory requirements have been satisfied.

- Obtaining a continuing or lot-by-lot certificate from an appropriate foreign government inspection authority or competent third party certifying that the imported fish or fishery product is or was processed in accordance with US regulatory requirements.

- Regularly inspecting the foreign processor's facilities to ensure that the imported product is processed in accordance with US regulatory requirements.

- Maintaining a copy of the processor's HACCP plan and a written assurance from the processor that the imported product is being processed in accordance with US regulatory requirements.

\footnotetext{
1721 CFR 110 .
}

1821 CFR 123. 
- Periodically testing the imported product and maintaining a written assurance from the processor that the imported product is being processed in accordance with US regulatory requirements.

- Other such verification measures that provide an equivalent level of assurance of compliance with US regulatory requirements.

Importers are entitled to utilize a competent third party to assist with or perform these verification procedures, including preparation of the importer's verification procedures. However, in all cases records must be kept that document the performance and results of the affirmative steps taken. Thus, there must be evidence that all imported fish and fishery products have been processed under conditions that are equivalent to US regulatory requirements. In the absence of such evidence it is assumed that the product is adulterated and entry at the border is denied.

Inspection authorities in some countries are issuing lists of processors that are in 'good standing' and are considered to be processing in accordance with US requirements. Importing from processors on these lists is one way of meeting the requirement to take 'affirmative steps'. However, this does not provide a guarantee of compliance and importers must be confident that they will be considered credible by the FDA.

The FDA has acknowledged that this approach is novel and will take time to be properly understood and implemented (FDA, 2002). Inspections are undertaken of US importers to determine whether they comply with the requirement to take 'affirmative step'. These indicate considerable improvement over time, although rates of non-compliance remain significant. For example, 52 percent of importers had written verification procedures in 2002 compared to 34 percent in 1998 (FDA, 2002). Of those with written procedures, 96 percent were considered adequate in 2002 compared with 74 percent in 1998. In recognition of this, the FDA has adopted a relatively flexible policy on compliance to date.

The US maintains a system of border inspection to ensure that imports meet the same standards as domestic products. Importers are required to file an entry notice and an entry bond with the US Customs Service pending a decision regarding the admissibility of the product. FDA is notified by Customs of the arrival of a consignment and makes a decision as to the article's admissibility based on a check of documentation and physical or other forms of inspection ${ }^{19}$.

In some instances a product is detained automatically at the border without physical examination. This is based on past history and/or other information indicating the product may not comply with US regulatory requirements. Where non-compliance is widespread, for example across a product category or imports from an entire country, all consignments may be detained.

\subsection{Conclusions}

There are considerable differences in the specific food safety requirements and the associated conformity assessment procedures applied to fish and fishery product imports in the four industrialized countries reviewed above. In Japan and Australia border inspection remains the

\footnotetext{
19 The US is also currently enacting controls on bio-security that will require importers to have a named agent in the US and to provide prior notification of consignments prior to their arrival at the port of entry.
} 
predominant approach to food safety controls for fish and fishery products. In the case of Japan, few specific regulations have been established for fish and fishery products. Rather, importers have to comply with general requirements that food products are safe and some limits relating to levels of microbiological contamination of end-products. In Australia, there is a requirement that domestic processors of fish and fishery products implement a specific food safety program, including HACCP. Exporters to Australia have the option of complying with these requirements and face lower levels of border inspection as a result. Exporters that do not comply are still able to export, but face a more extensive process of border inspection.

In both the United States and EU, imports of fish and fishery products must be processed in facilities that have equivalent standards to domestic facilities, including the implementation of HACCP. However, whilst in the United States the importer is required to take steps to ensure imports meet regulatory requirements, in the EU this is the responsibility of a "competent authority' in the exporting country. This requires not only that the exporter complies with EU regulatory requirements, but that the exporting country government has regulations and procedures in place in order to certify that this is the case. In both cases there are lower levels of border inspection.

Despite these differences, however, there are a number of common elements to the food safety control systems applied in these countries ${ }^{20}$. Examples include the required implementation of HACCP (or an equivalent system of food safety control) and inspection of processing facilities by a third party (whether government or a private certification agency) as a means of assessing compliance. Thus, in practice, efforts to comply with food safety requirements in one market (for example the EU) are likely to go a long way in meeting the requirements of another (for example the US or Australia). More generally, efforts to implement enhanced food safety controls can have a pay-off in terms of system-wide efficiency such that the costs of compliance with distinct requirements in individual export markets are reduced.

\section{NILE PERCH SECTOR IN KENYA}

In order to understand fully the impact that food safety standards have had on the Nile perch fisheries of the Kenyan shores of Lake Victoria, it is important to appreciate both the rate and manner in which the fisheries have developed. Overall, the picture is of a fishery that was predominantly local until the 1980s, in terms of both those employed and the markets that were supplied. Since, however, it has expanded and become integrated into a supply chain that is predominantly export-oriented. Whilst most commentators and researchers recognise that the aggregate economy of the fisheries has expanded, questions have been raised regarding the extent to which the fishing communities themselves have benefited. Further, there are concerns about the impact on local food security and on the sustainability of the fisheries in the medium to long term.

Lake Victoria is bordered by three countries, namely Kenya, Tanzania and Uganda. The total area of the Lake is $68,000 \mathrm{~m}^{2}$, of which Kenya holds $4,100 \mathrm{~m}^{2}$, or around 6 percent (Geheb and Binns, 1997). Prior to 1950, over 300 species of Haplochromis made up 80 percent of the biomass of the Lake. However, over the period 1950-62, six exotic species of tilapia were

\footnotetext{
${ }^{20}$ Although perhaps Japan to a lesser extent.
} 
introduced. Further, Nile perch was introduced to the Ugandan part of the Lake in 1954. It is estimated that over 200 of the original species are now extinct; most were of no commercial importance but are now considered to be relevant to the sustainability of Lake Victoria's ecosystem.

During the 1960 and 1970s, the Kenyan landed catch from Lake Victoria was stable at around 100,000 tonnes per annum (Abila and Jansen, 1997). At this time, the fishery was exploited solely by local fishers, 80 percent of which derived their primary income from fishing. Although average earnings declined as the number of fishers on the Lake increased (Francis and Hoddinott, 1983), income was distributed fairly evenly within the community. There were considerable investment barriers such that most boat owners had a single vessel and only sufficient gill nets that they could handle themselves.

Traditionally, the fishery consisted of wooden crafts propelled by sail. Very few had motorised propulsion. Throughout the 1960s and 1970s there was very little improvement in technology. This served to constrain the effectiveness of the fishing effort and thus limit the level of exploitation at sustainable levels (Geheb and Binns, 1997). Further, fisheries resources were managed judiciously and in a sustainable manner, with indigenous rules and regulations safeguarding fishing activities.

A vibrant artisanal processing and trading sector co-existed with the fishery, based on or near to landing beaches. This was dominated by small-scale operators, mostly women, from the local community. Fish that was not sold fresh was processed by smoking or sun-drying and carried to local inland markets. In general, the wholesale sector was relatively small and traders had little market power. Most fishers sold fish to a limited number of fishmongers with which they had a long-standing relationship (Abila and Jansen, 1997).

Prior to 1980, the Lake Victoria fishery existed largely without outside interference. Whilst the fishery was subject to regulation under the Fisheries Act, this was largely un-enforced (Abila and Jansen, 1997). Whilst the Fisheries Department collected catch statistics though Scouts, these were largely employed from the local community. Instead, the fishery was regulated by local norms and customs covering who was entitled to fish, in which seasons, which areas, types of fish gear that could be used, size of fish that could be landed etc.

Nile perch first appeared in Kenyan catch statistics in 1973 (Geheb and Binns, 1979). However, it was not until the 1980s that the Nile perch came to dominate the Lake Victoria fishery (Figure 3). Landings increased rapidly from 23,000 tonnes in 1981 , to 50,000 tonnes in 1985 and 123,000 tonnes in $1991^{21}$. Subsequently landings stabilised, although with significant annual variations. Thus, a tri-species fishery has become established, dominated by Nile perch, Omena and (to a much lesser extent) tilapia (Othina and Osewe-Odera, 1996).

${ }^{21}$ Landings increased at an even faster rate in Tanzania and Uganda. 
Figure 3. Total volume of fish landings in Kenya by source, 1990-2001:

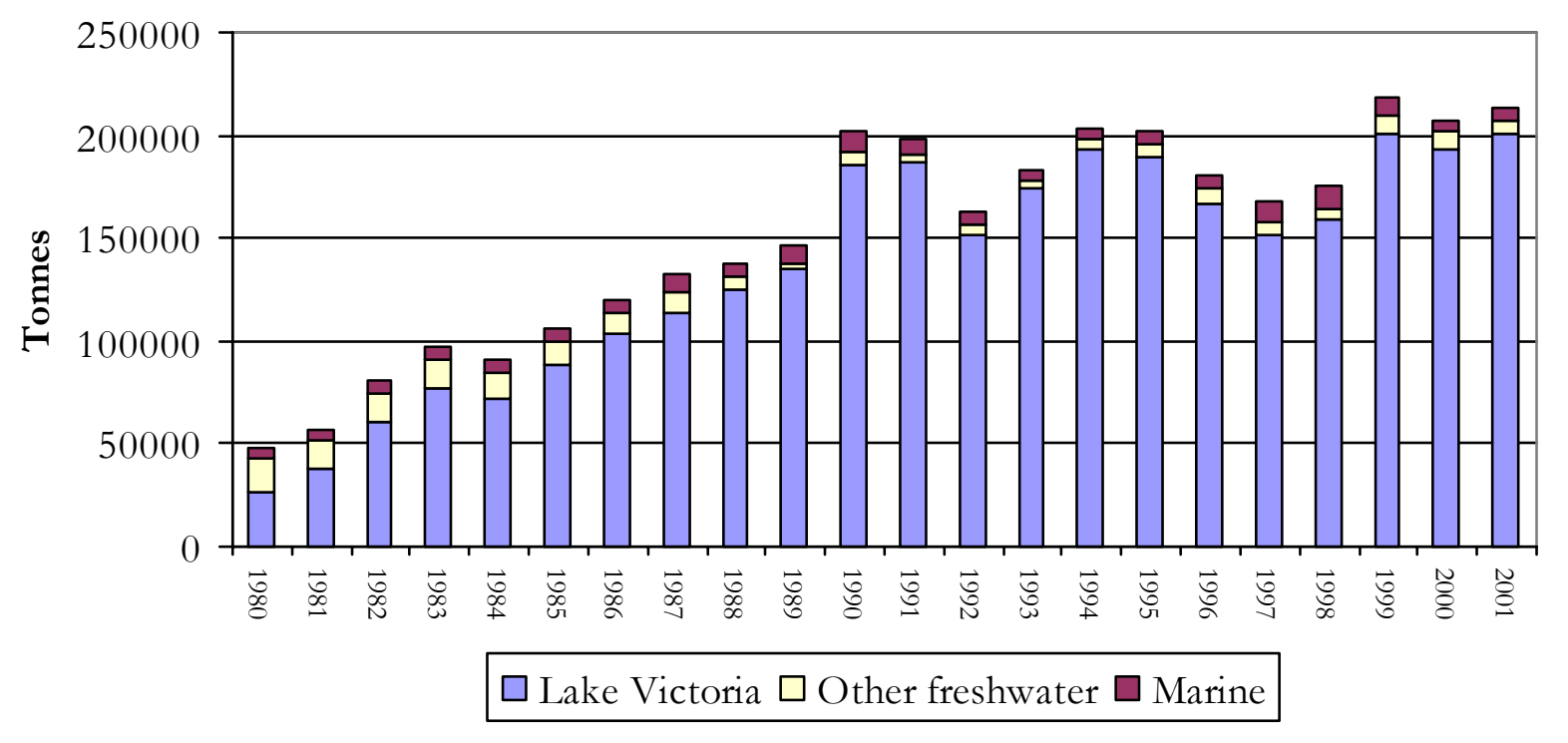

Source: $C B S$.

The development of the Nile perch fishery also served to enhance the dominance of Lake Victoria as Kenya's main fishing resource (Bokea and Ikaiara, 2000). Thus, whilst landings of fish at Lake Victoria accounted for around 50 percent of total fish supply in 1970, by the mid1990s this had increased to 94 percent. Today, when discussing domestic production and trade in fish and fishery products within a Kenyan context, one is inevitably referring to Lake Victoria.

During the early to mid-1980s, despite significant expansion, the Kenyan Lake Victoria fishery continued to be almost exclusively exploited by small-scale local fishers. There were no major changes in technology and practices and many women were involved in the processing and marketing of fish locally. However, towards the end of the 1980s, the Nile perch fishery changed dramatically. Thus, the number of fishers increased steadily from 11,000 in 1971, to 22,000 in 1989 and 30,000 in 1995. There was also significant growth in the number of registered vessels from around 4,000 in the early 1970s, to 5,000 in the late 1980s and over 11,500 in 2000. Simultaneously, there was investment in more advanced fishing equipment, in particular gill nets with larger mesh sizes (Abila and Jansen, 1997).

The growth of the Nile perch fishery has been accompanied by a significant expansion of the population of districts bordering the lake, from 2.55 million in 1989 to 3.73 million in 2001 (On'yan'ga, 2002). Around 60 percent are below 15 years of age. Thus, the fishery has become the major source of livelihood for a significant proportion of the Kenyan population. However, at the same time this expansion in population has meant that any growth in aggregate income in the area has been ever more widely dissipated.

Despite the expansion of the Lake Victoria fisheries, with the exception of a small number of trawlers that operate illegally, fishing is still undertaken from wooden boats with a crew of between two and four fisher-folk. Relatively few of the boats are motorized and the main technological advance has been in the type and size of net. Until the end of the 1990s, facilities 
on landing beaches remained rudimentary, often restricted to a covered area where fish was sold and in some cases a landing jetty. There was rarely a source of potable running water, toilets, chilled storage facilities or fencing to prevent entry of rodents and domesticated animals to the landing area. Despite the 'artisanal' nature of the Lake Victoria fishery, however, it has become fully integrated into the commercial economy and into a supply chain that extends globally (Harris et al., 1995; Ferguson et al., 1993).

In the early 1980s, a market developed for Nile perch in industrialised countries. Thus, the rapid growth of the Nile perch fishery was favoured by a huge market demand that soon expanded beyond the region (Reynolds and Greboval, 1988). In order to meet this demand, industrial fish processing factories were established, initially in Kenya and then in Tanzania and Uganda. Many of these received funding from multilateral agencies such as the African Development Bank (ADB), International Finance Corporation (IFC) and Aga Khan Foundation, as well as government development aid agencies (for example NORAD). Further, indirect support (for example in the form of research, training and technical assistance) was provided by agencies such as FAO, World Bank and UNEP. In turn, this lead to a fundamental change in the structure and modus operandi of the Nile perch supply chain.

The development of industrial processing facilities has displaced much of the artisanal fish processing sector at the landing beaches. Indeed, despite the demand for labour in the industrial processing sector, it is estimated that overall employment in the fish processing sector has declined significantly (Jansen, 1997). However, some artisanal processing does remain, including frying, sun-drying and smoking of juvenile Nile perch and Tilapia and sun-drying of Omena. Further, in close proximity to processing plants, a new sub-sector has evolved that processes waste materials, including fish skeletons (frames), off-cuts and skins. In recent years this sub-sector has itself been threatened because of the expansion of the industrial fish meal sector that competes for waste fish materials.

The evolution of the industrial fish processing sector has, in turn, induced changes in the upstream supply chain. Most notably, traditional fishmongers that typically had long-established relations with fishers have been replaced by agents and traders that purchase on behalf of the industrial processors (Harris et al., 1995; Medard and Wilson, 1998). Further, the total number of people employed in the marketing of fish has declined significantly. Those mongers that remain largely deal in juvenile Nile perch or Tilapia and thus operate outside of the export supply chain.

Initially, Nile perch exports were extremely profitable and industrial fish processing facilities were constructed in all three countries around the Lake. However, capacity soon exceeded the available supply of fish, a situation that has pervaded the supply chain for Nile perch ever since and sets the competitive environment in which all levels of the chain operate. Industrial fish processors have responded through more vigorous competition for supplies of fish at the landing beaches. For example, many provide equipment and/or credit to fishers (often via their agents) under sole-purchaser arrangements. Further, some have invested in collector boats to gather fish from remote beaches in order to expand their supply area. 
It will be readily apparent from the foregoing discussion that Nile perch fishery has come to dominate the fishery of Lake Victoria and brought about fundamental changes in the structure and modus operandi of the entire fish supply chain. More fundamentally, the focus of the supply chain has switched from local, through regional, to industrialised country markets. Local fishing communities have become dependent upon global markets. However, whilst the processing sector has become industrial in terms of both scale and the processes employed, fishing and landing methods remain artisanal in nature. The key factor constraining both the current operation of the chain and its future evolution is the supply of fish. Whilst the global demand for Nile perch is seemingly 'limitless' (at least within the current purview), the processing sector is characterised by significant structural over-capacity. In turn, the exploitation of the Lake Victoria fisheries without due attention to their infrastructural development and effective management is no longer a sustainable strategy.

\subsection{Supply chain for Nile perch}

The Lake Victoria fisheries have become integrated into a complex system of supply chains that operate at three distinct levels:

- Localised trading along the lake shore and markets within the hinterland.

- Inter-regional trade between Kenya, Uganda and Tanzania.

- Extra-regional international exports.

These chains differ fundamentally in their structure and modus operandi. The supply chain for local consumers and inter-regional trade is characterised by high levels of product diversity across species and levels and forms of processing, including, fresh, smoked and dried fish. There is little or no integration along the chain and in some cases, particularly trade with distant urban areas and/or neighbouring countries, there are numerous intermediaries. This is in stark contrast to the supply chain associated with extra-regional exports (LVFRP, 1999a), that is characterised by:

- High levels of vertical integration in an attempt to control each of the inter-connected stages.

- Low levels of product diversity; the chain only handles one species of fish, namely Nile perch.

- Sophisticated processing facilities that employ trained labour, although the level of processing and value-added is generally minimal and most fish is exported frozen in bulk packs.

- High levels of capital investment and significant economies of scale such that processing facilities need to operate at or near capacity in order to be profitable.

- Utilisation of air and sea freight to access distant markets.

To all intents and purposes these two supply chains operate side-by-side but there is very little direct competition between them. Rather, the extra-regional supply chain is supplied as a first resort, with only rejected fish entering the local and regional supply chains. The remainder of this section describes the extra-regional supply chain in some detail.

Lake Victoria fishery

In 2000, there were 38,431 fishers operating from 297 landing beaches along the Kenyan shore of Lake Victoria (Fisheries Department, 2000). Whilst this indicates an average of around 130 
fishers per landing beach, most beaches are small in terms of both number of fishers and volume of catch. Indeed, over 60 percent of fishers are concentrated in two main districts, namely Suba and Bondo.

The total recorded fishing vessels in 2000 was 13,800 , including 11,515 operational fishing boats, 1,879 derelict fishing boats and 409 transport craft (Fisheries Department, 2000). Most fishing boats are sesse canoes of wooden construction. Metal trawlers are banned on the Lake as part of conservation measures. The vast majority of craft are propelled by paddle or sail. Only 5 percent have an inboard or outboard engine.

The main fishing method for Nile perch on Lake Victoria as a whole is gill nets which are used by over 85 percent of fishers (LVFRP, 1999b). Gill net boats generally have a crew of two or three, although some have as many as four. However, in Kenya purse seines are used by around 36 percent of fishers. These are generally operated by a crew of four. Most boats target only one species, predominantly Nile perch.

The majority of landing beaches along the Kenyan shore of lake Victoria have only rudimentary infrastructure (see for example Figure 4). Indeed, in 1998 only 27 percent had a permanent covered structure (banda) (see for example Figure 5) for grading and marketing of fish (Table 1). Only 20 percent had an all-weather road to the beach. Very few landing beaches had any form of fish and/or cold storage. Where existing, these were typically cooler boxes that required ice to store fish for prolonged periods of time. In some cases these had been donated by research projects that had been competed or had been constructed by a fish trader (as in Figure 6) or supplied by processors to traders or agents.

Historically, a number of efforts have been made to organise fishers at each landing beach. These are described in Box 1.

Fishing boats are generally operated by the boat owner or a boat operator on behalf of an absentee owner with a paid crew. The most common form of remuneration allocates a flat proportion of the catch each day to the crew less costs (for example food, fuel, wear and tear of equipment etc) (LVFRP, 1999b). Other forms of payment include the designation of certain days on which the entire catch is divided amongst the crew or the opportunity for the crew to use their own gear to catch fish from the owner's boat.

Most fishers undertake activities in addition to fishing (LCFRP, 1999a). Reflecting the traditional tri-economy of the region bordering Lake Victoria, the most common additional activities are agriculture and livestock. However, a significant proportion has diversified their livelihood by investing in a local store or hotel, or by renting out rooms in their own house. 
Figure 4. Landing area at Dunga beach:

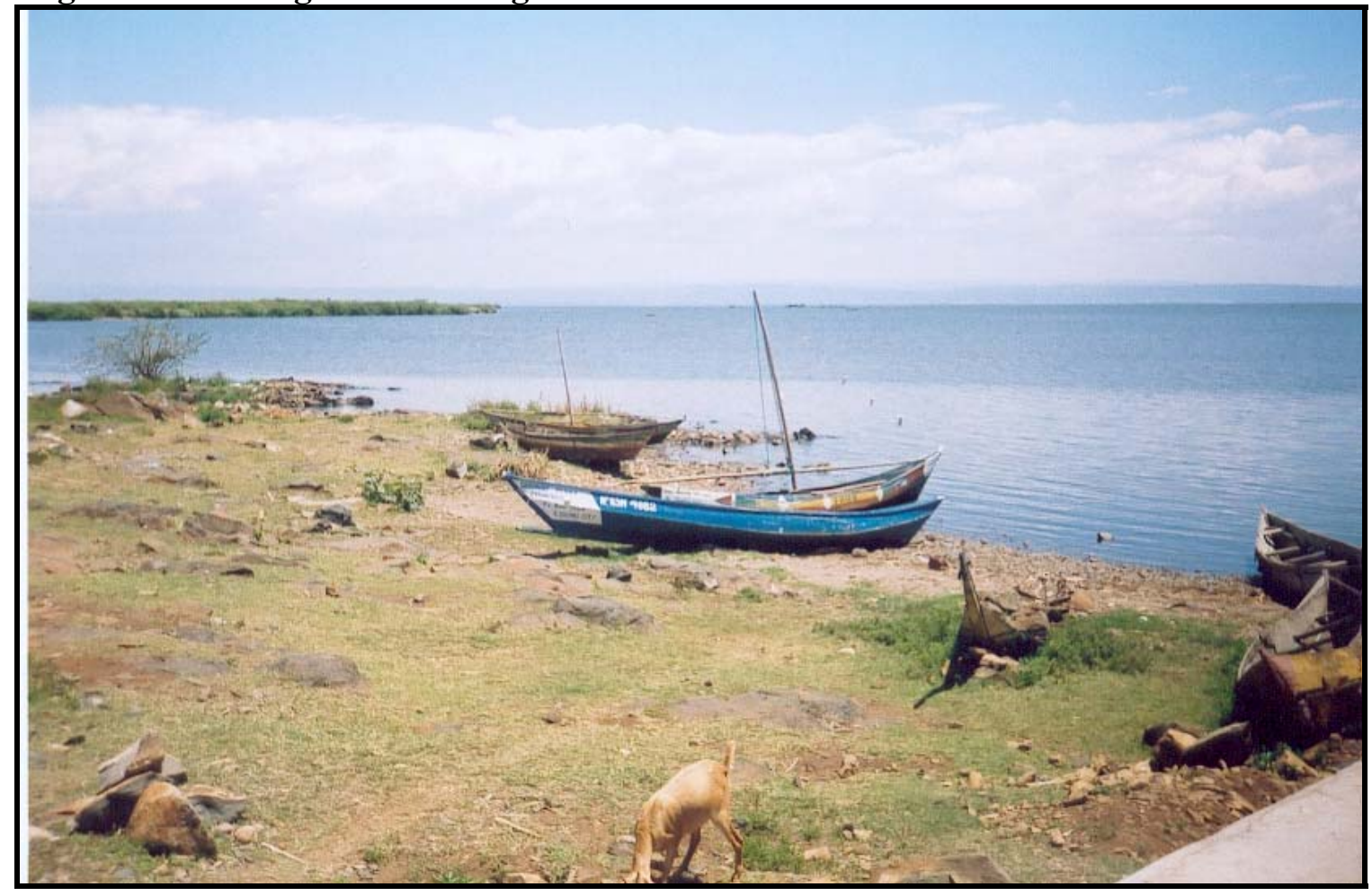

Figure 5. Banda at Kaloka beach:

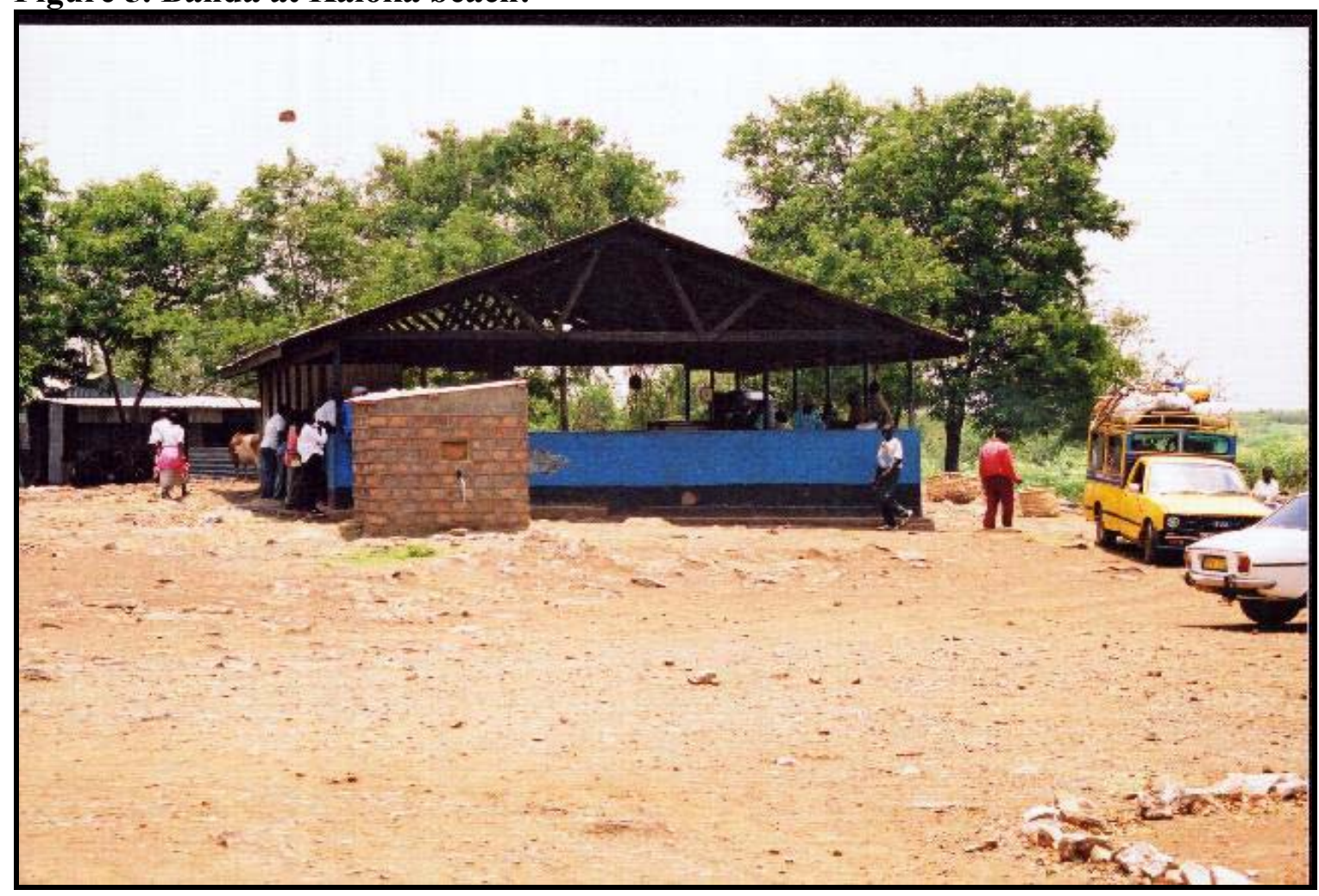


Figure 6. Fish storage facility at Kaloka beach:

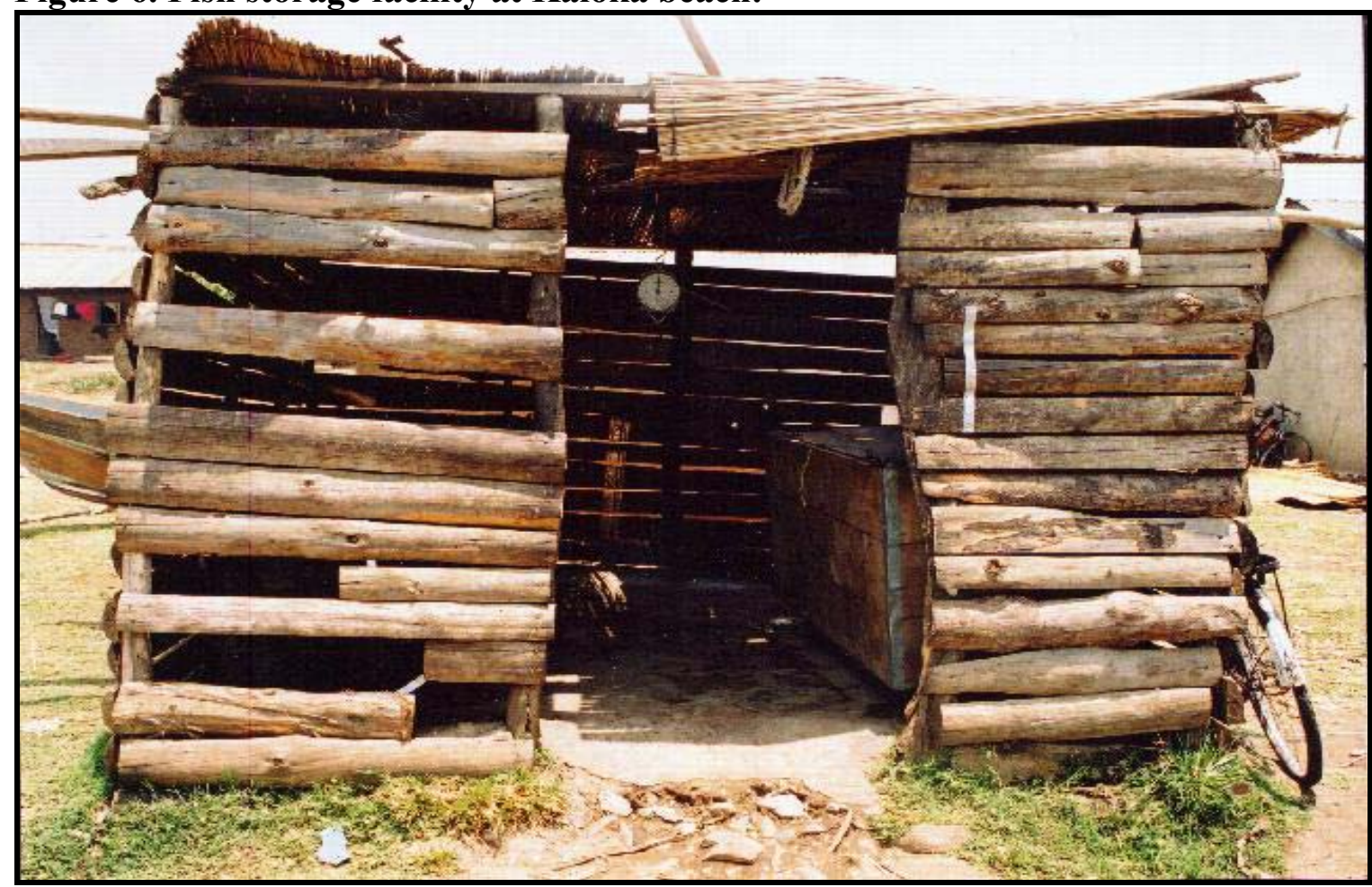

The majority of fishers only sell their landed catch at their home beach (LVFRP, 1999a; 1999b; Hoekstra et al., 1991). However, there is evidence that landing of fish at multiple beaches and collection and distribution of fish by boat are becoming more common (Gibbon, 1997; Odongkara, 1992). The main purchasers of fish at landing beaches are agents of industrial fish processors, although there is frequently a multitude of other purchasers including bicycle, pick up vehicle traders and local traders/processors (LVFRP, 1999a; 1999b). Relatively few fishers have formal buying arrangements with agents, for example selling fish exclusively to a particular agent in return for credit or gear, although this is increasingly the norm for Nile perch (Hoekstra et al., 1991; Geheb, 1997; LVFRP, 1999a).

Local fishing communities experience considerable problems marketing their catch. Particular issues include significant price fluctuations (even on day-to-day basis), transport problems insufficient buyers and lack of cold storage/ice (LVFRP, 1999b). In most cases little or no bargaining over the price and/or acceptability of fish takes place; rather the most common scenario is that the price is set by the buyer (LVFRP, 1999a). Further, the flow of information to fishers from further down the supply chain regarding price, market demand and/or quality requirements is far from optimal (Visser, 2003).

\section{Fish traders/processors}

Fish traders and local processors have always played an important role in the Lake Victoria fishery, although the nature of this level of the supply chain has changed fundamentally as a result of the evolution of the industrial fish processing sector. In particular, agents acting as sole suppliers to a particular fish processing plant have come to play a more prominent role than local traders (see Section 4.2.3). 
Table 1. Infrastructure at landing sites on Kenyan shores of Lake Victoria:

\begin{tabular}{|c|c|}
\hline Facility & $\begin{array}{l}\text { Number } \\
\text { (Percent) }\end{array}$ \\
\hline Banda & $\begin{array}{c}80 \\
(26.9 \%) \\
\end{array}$ \\
\hline All-weather road to beach & $\begin{array}{c}60 \\
(20.2 \%)\end{array}$ \\
\hline Electricity & $\begin{array}{c}27 \\
(9.1 \%) \\
\end{array}$ \\
\hline Fish store & $\begin{array}{c}16 \\
(5.4 \%) \\
\end{array}$ \\
\hline Pontoon/Jetty & $\begin{array}{c}11 \\
(3.7 \%) \\
\end{array}$ \\
\hline Cold room & $\begin{array}{c}1 \\
(0.3 \%)\end{array}$ \\
\hline
\end{tabular}

Source: Fisheries Department (2000).

Abila $(1995 ; 2002)$ has identified three main supply routes between fishers and the industrial fish processing plants as part of the export supply chain:

- Sales by fishers to agents of industrial fish processing plants: On many beaches, for example where the cooperative society is dysfunctional and/or fisher associations have not been established, fishers sell their fish directly to agents.

- Sales by fisher associations to agents of industrial fish processing plants. For example, on Sori-Karungu beach three associations have close links with agents, bypassing the cooperative. The agents provide fishing gear to the groups in return.

- Sales by cooperative societies to agents of industrial fish processing plants: For example, on Mugabo beach all fish is delivered to the cooperative, including from fisher associations. The cooperative is the sole seller of fish on the beach to the agents.

- Sales by cooperative society direct to industrial fish processing plants: This route by-passes the traders/agents altogether. For example, on Wichlum beach all fish is handled by the cooperative. The cooperative is active in the marketing of the fish, some of which is delivered directly to the industrial fish processors.

Within Kenya as a whole, the first two of these routes is most common, indicating the important role played by agents within the export supply chain. However, alongside these agents operate a range of local traders and artisanal processors that purchase fish to supply to local markets in a fresh or processed form. Many of these are from the local community or hinterland.

The supply chain for fresh fish normally involves the direct supply of fish to agents from fishers (or through their cooperative society or fisher association). There is very limited use of wholesalers (Figure 7). Thus, the supply chain is shorter and more amenable to coordination and control. This contrasts, for example, to the more traditional supply chain for locally processed fish which can involve both direct sales of fresh fish to the processor or the use of wholesale markets. 


\section{Box 1. Organisation of fishers at landing beaches along the Kenyan shores of Lake Victoria:}

During the 1950s, loose associations were formed often under the authority of an existing clan institution. These were community-based within the context of traditional social structures. The first attempt at centralised management of fishing communities was the establishment of a Fisheries Unit during the 1960s under colonial rule, taking away control from local communities.

During the 1970s, existing fisher organisations were converted into Fishermen Cooperative Societies administered under the Cooperative Act and promoted and managed by the Ministry of Cooperative Development. These aimed to assist fishing communities in the marketing of fish, mobilisation of savings for beach improvement, provision of credit to fishers and, more generally, to improve the standard of living of the communities (Jansen, 1997; Abila, 1995; 1998). Over time and into the 1990s, the number of cooperatives increased significantly. However, during the 1980 s and 1990s many became dormant or were under-utilised., whilst others collapsed or were disintegrated (Ong'ang'a, 2002).

In the early 2000s, fisherfolk associations emerged as a new form of organisation as a means to by-pass the problems encountered with cooperative societies. These were registered by the Ministry of Culture and Social Services, although it had no remit to promote their establishment and/or supervise their operations (Ong'ang'a, 2002). Today, cooperative societies and fisherfolk associations operate side-by-side and fishers are frequently members of both. Increasingly, however, the fisherfolk associations have come to dominate the marketing of fish.

On most beaches along the Kenyan shore of Lake Victoria a Beach Leader is appointed by the community. This individual is recognised by the Fisheries Department, although there is no legal provision in the Fisheries Act. The Beach Leader heads a committee of five to seven community members and is charged with ensuring fishing is undertaken in compliance with rules and regulations, promotes peace and security at the beach, solves misunderstandings between fishers and fishmongers and receives and approves immigrant fishers. More generally, the Beach Leader acts as an intermediary between the community and the Fisheries Department and promotes the development of infrastructure at the beach. This system worked well until the end of the 1970s, but has become less effective in recent years.

In recent years, Beach Management Units (BMUs) have been established at landing beaches in an attempt to effect management of fishing communities and communication with local fisheries officials (see for example Owino, 1999; Visser, 2003). The roles of the BMU are to:

- Ensure fisher folk carry out fishing and fish handling responsibly.

- Ensure both the fisher folk and fish handlers at the landing site adhere to hygienic handling standards

- Disseminate information on responsible fishing and handling methods.

- Ensure the hygiene standards of the landing sites are maintained.

To some extent, BMUs reflect a return to more 'local' management of fishing communities, although external control and influence remains significant and effectiveness of BMUs is still open to question. 
Most trading in Nile perch and other fish occurs at the landing beach. Increasingly, however, agents are utilising transporter boats to gather fish from distant beaches or direct from fishing vessels which is then landed at a single beach. This widens their supply base and enables the newly caught fish to be cooled in ice at the earliest opportunity. The majority of traders/processors only deal with Nile perch (LVFRP, 1999a).

Figure 7. Suppliers of fish to Lake Victoria fish traders/processors:

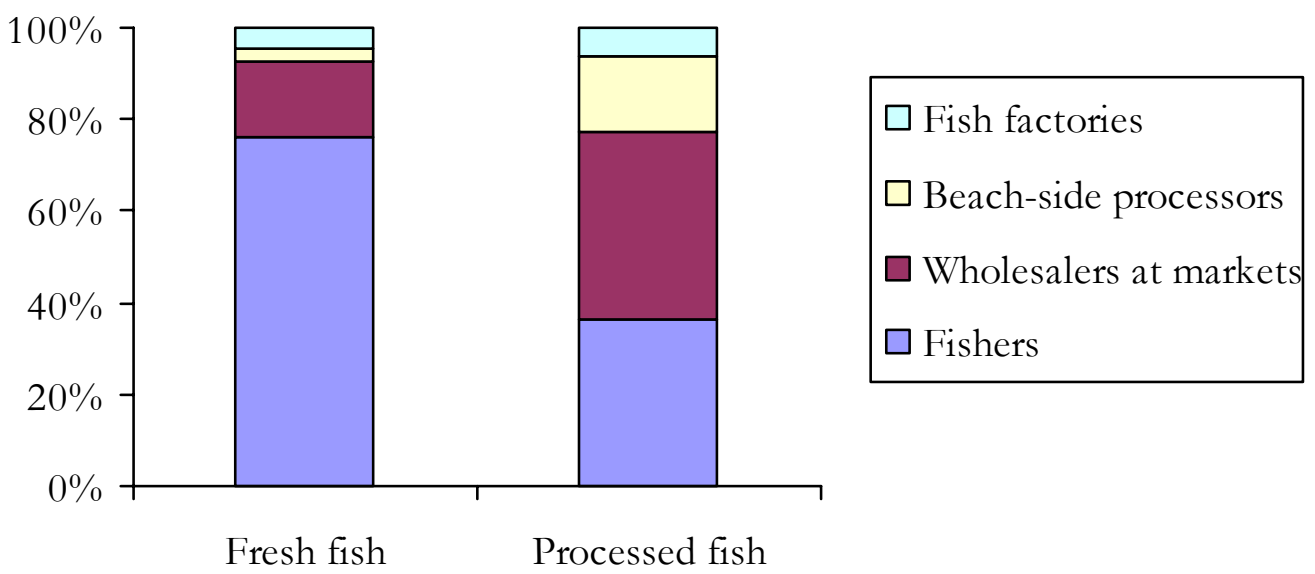

Source: LVFRP (1999a).

In many cases the conditions in which Nile perch is graded and sold at the beach are rudimentary. At more developed beaches this occurs in a permanent banda (as in Figures 8), although in some it still takes place in the open air. Often fish is placed on the ground and there is no supply of potable running water or cool storage. Further, the banda is not isolated from the surrounding area with fencing and is accessible by domestic animals and wildlife and members of the community not involved in fish marketing.

Industrial fish processing ${ }^{22}$

The industrial fish processing sector first started to evolve in Kenya at the start of the 1980s and by 1987 ten factories were operational (Reynolds and Greboval, 1988; Gibbon, 1997). At this time no facilities had been established in Tanzania or Uganda and Kenyan processors sourced fish in all three countries. Initially, factories were situated in Kisumu and Nairobi, but more recently facilities were established nearer to landing beaches in Homa Bay and Migori in an attempt to reduce transport costs and maintain quality. Processing capacity continued to expand in the early 1990s, with the number of facilities peaking at 15 in 1995 (Bokea and Ikaiara, 2000).

A significant proportion of traders/processors experience problems with fish spoilage (LVFRP, 1999a). These problems are related in particular to poor storage conditions and, where trading occurs in the open air, rain (Table 2). Another significant problem faced is transportation, due largely to the poor state of the roads in the region.

${ }^{22}$ For a more detailed review see Wakwabi et al., 2003. 
Figure 8. Fish traders on Kaloka beach:

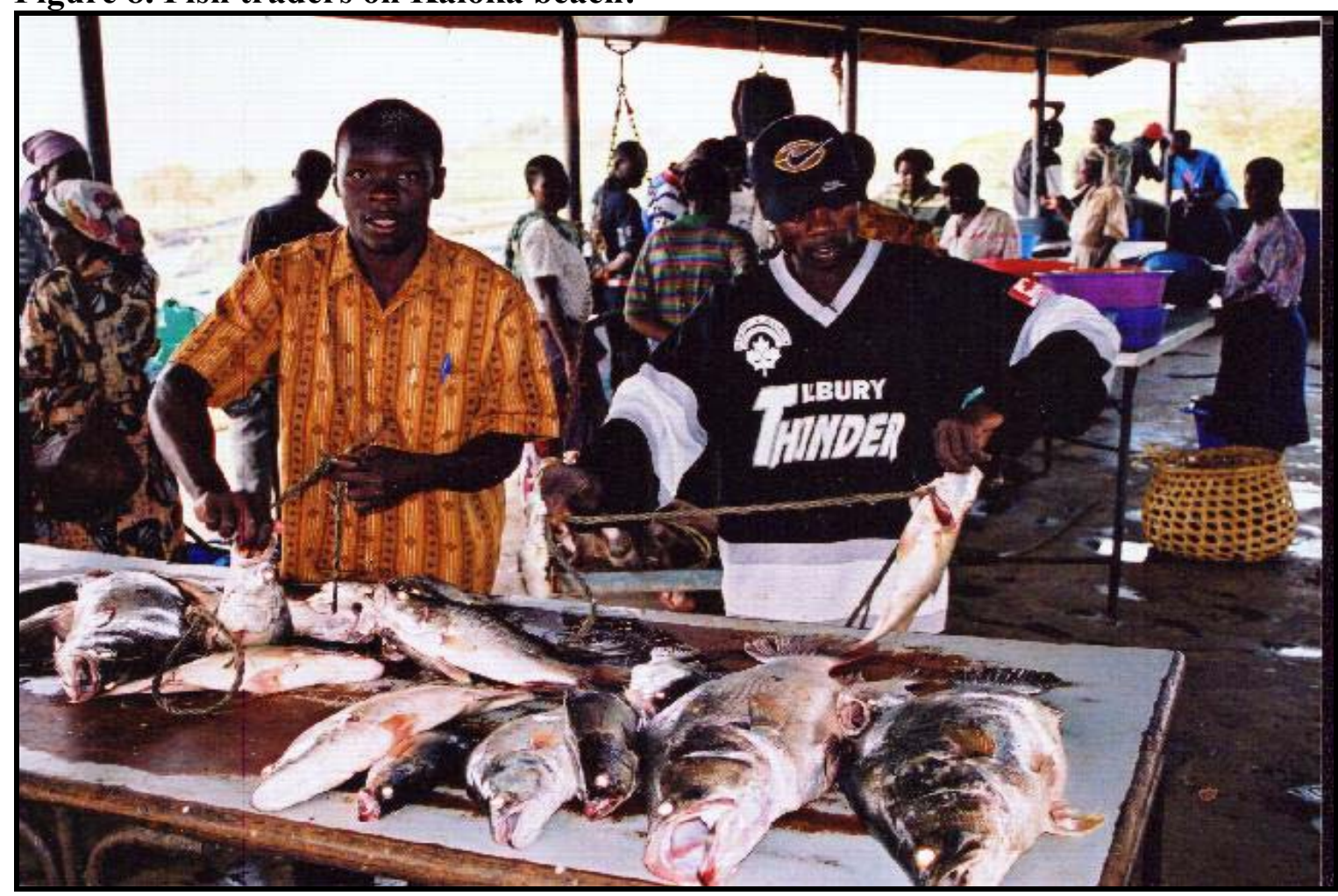

Industrial fish processing facilities in Kenya are predominantly owned by the domestic Asian population and operated as family businesses. However, there has been limited foreign direct investment. One factory is Israeli-owned and a further two have Israeli partners (Abila and Jansen, 1997).

Table 2. Problems with fresh fish spoilage amongst Lake Victoria fish traders/processors:

\begin{tabular}{|c|c|}
\hline Activity & Frequency \\
\hline Poor handling & $15.7 \%$ \\
\hline Poor storage facilities & $34.2 \%$ \\
\hline Rain & $23.3 \%$ \\
\hline Other & $26.7 \%$ \\
\hline TOTAL & $100.0 \%$ \\
\hline
\end{tabular}

Source: LVFRP (1999a).

By 1997, the industrial fish processing sector employed around 2,400 people, of which 75 percent were temporary or casual workers (Abila and Jansen, 1997). However, there is evidence that overall employment in fish processing has declined significantly over time, reflecting the relatively high levels of capital intensity within the industrial processing sector.

Industrial fish processing facilities source raw Nile perch in a variety of ways. The most common is to utilise contracted and/or independent agents that purchase from fishers (either directly or through Cooperative Societies or Fisher Associations) (Abila and Jansen, 1997; 
LVFRP, 1999a; Mitullah, 1999). Generally, the factory provides transportation from the landing beach and ice, but does not take possession of the fish until it arrives at the factory and has been graded. Factories may also buy direct from fishers, by-passing the agents, particularly where a cooperative is well organised to market fish ${ }^{23}$. In these cases the fish may be transported in the cooperative's own vehicle or a vehicle may be leased to the cooperative. Although relatively rare, some factories own their own vessels and employ fishers directly.

A number of processors provide financial support to agents, for example in the form of cash advances to purchase fish. They may also supply fishing equipment to fishers through agents in a bid to establish sole supplier relations. The typical agent can handle three to five tonnes of fish in a day and earns commission of around 10 percent, as the difference between the purchase and selling price (Abila and Jansen, 1997). In many cases factories have a long-standing relationship with their agent. Although there is no formal written contract, there is generally prior agreement on the delivery price and size and quality of fish.

The rapid growth of the industrial fish processing sector was motivated by the high and rising demand for Nile perch in exports markets, particularly within the EU. However, after peaking in the mid-1990s, exports began to diminish because of difficulties relating to the supply of Nile perch and fish quality (Bokea and Ikaiara, 2000). It is estimated that the sector as a whole was operating at 55 percent of its 380 tonne/day capacity in 1997 (Abila and Jansen, 1997), of which three factories accounted for over half of total operating capacity (Figure 9).

Although fish processing plants continued primarily to handle Nile perch, some started to process tilapia for export towards the end of the 1990s (Abila and Jansen, 1997). There was also consolidation in the sector and a number of operators established sister factories in Tanzania and/or Uganda where the supply of fish has been more plentiful. Until recently, these were used in part as a source of supply of raw or semi-processed fish for their Kenyan plants (Mitullah, 1999).

The major on-going issue for the sector is the landed supply of Nile perch. It is evident that the rapid expansion of the Nile perch fishery is not sustainable. Indeed, catches have tended to decline despite continual increases in the fishing effort. This has been exacerbated by the rapid spread of water hyacinth that has rendered some landing beaches inaccessible. Initially these supply problems were overcome by sourcing outside of Kenyan waters. Indeed, until recently there was evidence of significant 'informal' or 'undocumented' exports of fish from Tanzania and Uganda (Reynold et al., 1995).

In an effort to secure supplies of raw fish from Kenyan waters, some processors have extended their provision of credit or nets and other gear to fishers, through their agents (Abila and Jansen, 1997). In some cases, they have built bandas, storage facilities and even jetties at landing beaches in order to create leverage in the local marketplace. Others have invested in motorised boats to collect fish and deliver to insulated vehicles. It is evident, however, that these efforts have been less successful in Kenya than in Tanzania, where whole fleets of fishing boats have become established that supply a single factory(LVFRP, 1999a). In part, this reflects the better

23 Although this is more common in Tanzania than Kenya. 
organisation of fishers in Tanzania where the Tajiri (proprietor) in charge of a fleet of vessels is able to negotiate directly with a fish processor.

Figure 9. Capacity and operating volumes of operational fish processing facilities prior to ban on exports to the EU, 1997:

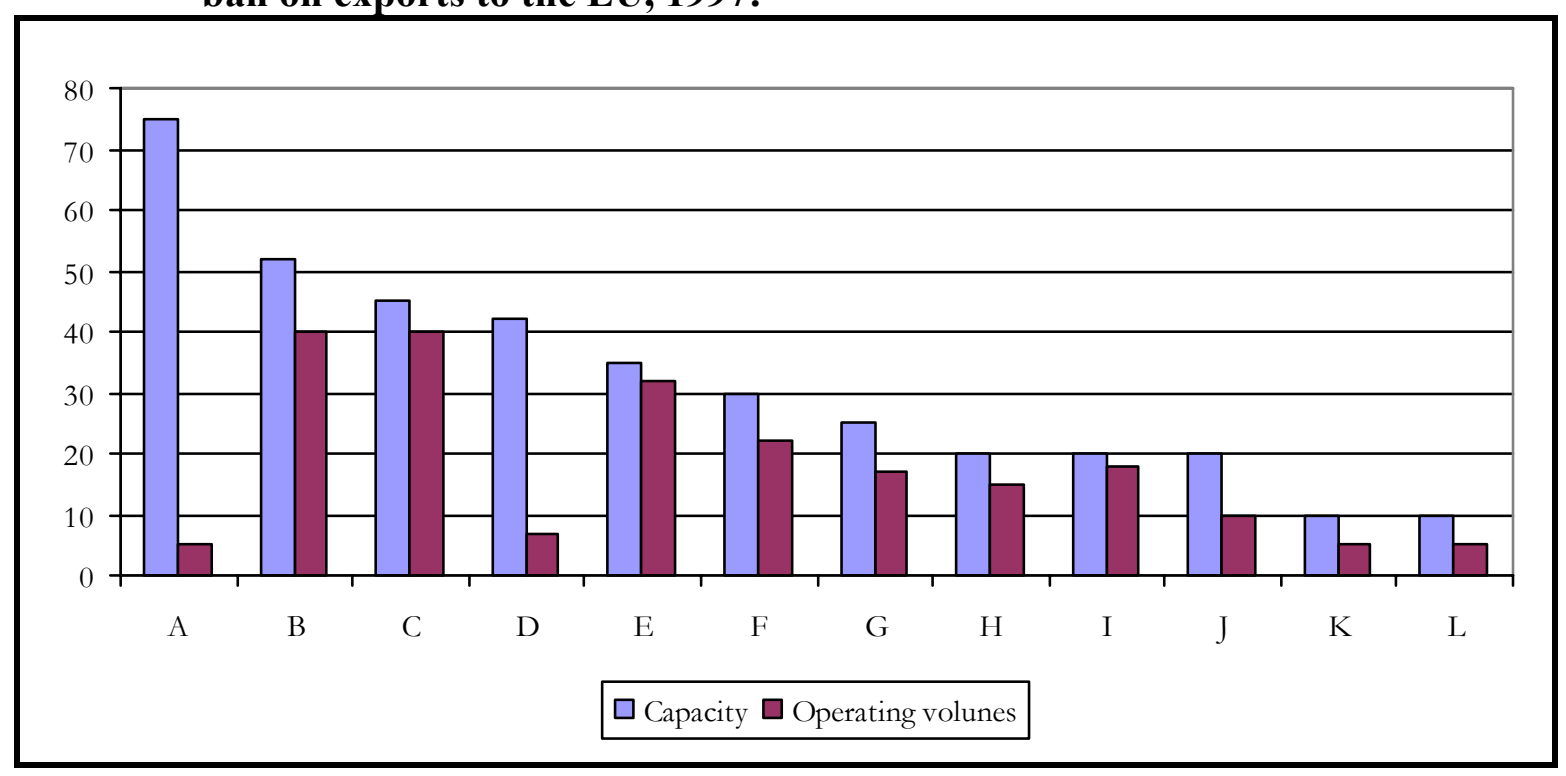

Source: Abila and Jansen (1997).

The sector as a whole continues to be characterised by low levels of value added; most exports are in the form of block frozen bulk packs of semi-processed filets. This is a particular problem given the increasing constraints on the supply of raw fish. Some processors have explored opportunities for value-added products and/or have made attempts to diversify into other sectors, for example bakery products, meat and ice cream. However, these remain the exception and gross margins remain both low and extremely sensitive to the landed price of Nile perch.

The industrial fish processing sector produces a number of by-products and wastes that also generate value. The fish maws have a high value as an export product to China and Japan. These are dried and sold on to traders. Waste products, including the fish skeleton (frame), skin, off-cuts and fat are sold to local artisanal processors, either directly or through traders (Gibbon, 1997; Abila and Jansen, 1997; Jansen, 1997) or to industrial fish meal plants.

The growth in the industrial fish processing sector was mirrored by the establishment and expansion of a separate sub-sector that processed these waste by-products (Abila, 1995; 1996; Abila and Jansen, 1997; Jansen, 1997). This sub-sector is generally located in direct proximity to industrial fish processing facilities. Much of the processing is undertaken in the open involving rudimentary techniques such as flash frying and using fish fat and skins as fuel. The processed product is bundled and supplied to urban markets throughout Kenya. Abila and Jansen (1997) estimate that 600 people (75\% of which are women) are employed in the processing of Nile perch frames and other by-products in Kisumu and a further 400 in Homa Bay and Nairobi. However, this activity is being threatened by competition for fish processing waste 
from industrial fish meal plants ${ }^{24}$. These plants currently process around 17,000 tonnes of frames per day, accounting for 59 percent of the total supply.

\subsection{Food safety controls in the Nile perch sector}

As described in Section 8, significant efforts have been made in recent years to upgrade hygiene and other food safety controls along the Nile perch supply chain in Kenya, largely as a result of the imposition of restrictions on exports to the EU. This section, however, provides an assessment of the state of food safety capacity in Kenya in 1997, largely before these reforms were implemented. It draws upon the inspection reports of the European Commission and other previously published assessments (for example Landell Mills, 2001).

In general, the basic elements of a food safety control system were in place in the mid-1990s, although in many cases these were outdated and/or inadequate for the task of complying with food safety requirements in industrialised country markets (Table 3). Thus, for example, although there was an established system for the inspection and licensing of fish processing facilities to ensure minimum levels of hygienic practices, these were poorly enforced. Further, controls on imports and the control and certification of exports were in place, but inadequate. Many industrial fish processors had not implemented complete quality management systems, including HACCP. Frequently, pest control was rudimentary and general hygiene procedures and standards were inadequate. At landing beaches there was a lack of awareness, ability and/or unwillingness to comply with basic hygiene procedures.

Although no specific legislation relating to hygiene in the processing and marketing of fish and fishery products was in place, various acts and regulations specified including: Public Health Act; Food, Drugs and Chemical Substances Act; Food Hygiene Regulations; Fisheries Act; and Standards Act. Further, the Kenya Bureau of Standards (KEBS) had established a Code of Hygiene Practice for the fish and fishery sector in 1986. However, in most cases legislation was out-dated and not compatible with international standards.

Perhaps the more fundamental weakness was in the implementation and enforcement of existing regulatory requirements. In general, the number of inspectors and other personnel was inadequate to inspect and monitor compliance on landing beaches and industrial fish processing plants. Indeed the number of fish scouts, for example, had declined due to budgetary constraints. Whilst inspectors were generally well trained, they were in need of up-dating, for example in the principles of HACCP, and in some cases lacked access to basic infrastructure and equipment. For example, inspectors often had to request transport from the fish processors that they were charged to enforce. Generally, laboratory facilities were poorly functioning and otherwise outdated. Frequently, levels of staffing were insufficient and/or personnel were in need of retraining.

\footnotetext{
${ }^{24} \mathrm{It}$ is estimated that over 2,000 people were involved in this sub-sector in 1990 (Abila and Jansen, 1997).
} 
Table 3. Strengths and weaknesses of hygiene and other food safety controls for fish and fishery products in the mid-1990s:

\begin{tabular}{|c|c|c|c|}
\hline \multirow[t]{3}{*}{ Element of Capacity } & \multicolumn{3}{|c|}{ Sector } \\
\hline & \multicolumn{2}{|c|}{ Collective } & \multirow[t]{2}{*}{ Exporters } \\
\hline & Public Sector & Private Sector & \\
\hline Internal surveillance & $\begin{array}{l}\text { Some capacity but generally } \\
\text { inadequate }\end{array}$ & Missing & $\begin{array}{l}\text { Some capacity but generally } \\
\text { inadequate }\end{array}$ \\
\hline Import controls & $\begin{array}{l}\text { Legislation exists but not enforced } \\
\text { particularly relating to movements of } \\
\text { fish between Kenya, Tanzania and } \\
\text { Uganda }\end{array}$ & Missing & $\begin{array}{l}\text { Some capacity but generally } \\
\text { inadequate }\end{array}$ \\
\hline Emergency quarantine & $\begin{array}{l}\text { Some capacity but generally } \\
\text { inadequate }\end{array}$ & Missing & $\begin{array}{l}\text { Some capacity but generally } \\
\text { inadequate }\end{array}$ \\
\hline Export controls and certification & Some capacity but inadequate & Missing & Instances of non-compliance \\
\hline $\begin{array}{c}\text { Responsiveness to new/emerging } \\
\text { issues }\end{array}$ & $\begin{array}{l}\text { Lack of monitoring and ability to } \\
\text { respond to emerging issues }\end{array}$ & Missing & $\begin{array}{c}\text { Poor } \\
\text { Lack of co-ordination }\end{array}$ \\
\hline Risk analysis & Missing & Missing & HACCP generally not implemented \\
\hline Analysis and diagnosis & $\begin{array}{l}\text { Some capacity but generally } \\
\text { inadequate }\end{array}$ & Missing & $\begin{array}{l}\text { Some capacity but generally } \\
\text { inadequate }\end{array}$ \\
\hline Controls on inputs & $\begin{array}{l}\text { Some capacity but generally } \\
\text { inadequate }\end{array}$ & Missing & $\begin{array}{l}\text { Some capacity but generally } \\
\text { inadequate }\end{array}$ \\
\hline Pest and disease control & $\begin{array}{c}\text { Some capacity but generally } \\
\text { inadequate }\end{array}$ & Missing & $\begin{array}{c}\text { Some capacity but generally } \\
\text { inadequate }\end{array}$ \\
\hline $\begin{array}{l}\text { Hygienic practices in production, } \\
\text { processing and distribution }\end{array}$ & $\begin{array}{l}\text { Level of inspection and enforcement } \\
\text { inadequate }\end{array}$ & Missing & $\begin{array}{l}\text { Variable amongst industrial fish } \\
\text { processors. Best to EU standards, } \\
\text { but worst require major structural } \\
\text { and operational up-grading } \\
\text { Very poor on landing beaches }\end{array}$ \\
\hline Monitoring & $\begin{array}{c}\text { Some capacity but generally } \\
\text { inadequate }\end{array}$ & Missing & $\begin{array}{c}\text { Some capacity but generally } \\
\text { inadequate }\end{array}$ \\
\hline Identification and traceability & $\begin{array}{l}\text { Some capacity but inadequate } \\
\text { Poorly implemented }\end{array}$ & Missing & $\begin{array}{c}\text { Some capacity but generally } \\
\text { inadequate }\end{array}$ \\
\hline
\end{tabular}


Table 4. Management capacity constraints relating to hygiene and other food safety controls for fish and fishery productsin the mid-1990s:

\begin{tabular}{|c|c|c|c|}
\hline \multirow[t]{3}{*}{ Element of Capacity } & \multicolumn{3}{|c|}{ Sector } \\
\hline & \multicolumn{2}{|c|}{ Collective } & \multirow[t]{2}{*}{ Exporters } \\
\hline & Public Sector & Private Sector & \\
\hline Administrative procedures & $\begin{array}{c}\text { Overly bureaucratic } \\
\text { Overlap and lack of co-ordination of } \\
\text { responsibilities between government } \\
\text { agencies }\end{array}$ & Missing & $\begin{array}{c}\text { Lack of co-operation/co-ordination } \\
\text { between exporters } \\
\text { Lack of documented hygiene } \\
\text { procedures }\end{array}$ \\
\hline Legislation & $\begin{array}{l}\text { Outdated } \\
\text { Fragmented }\end{array}$ & $\begin{array}{l}\text { No private sector codes of practice or } \\
\text { guidelines } \\
\text { Generic private sector capacity } \\
\text { existed but not utilised }\end{array}$ & - \\
\hline Enforcement/control & $\begin{array}{l}\text { Inadequate inspectors and/or } \\
\text { inspectors inadequately trained }\end{array}$ & Missing & $\begin{array}{c}\text { Lack of quality assurance personnel } \\
\text { and/or supervisors trained in hygiene } \\
\text { etc. }\end{array}$ \\
\hline Physical infrastructure & $\begin{array}{c}\text { Lack of properly functioning and } \\
\text { adequately resourced laboratory } \\
\text { facilities }\end{array}$ & $\begin{array}{c}\text { Some private sector capacity, for } \\
\text { example laboratory facilities, but not } \\
\text { utilised }\end{array}$ & $\begin{array}{c}\text { Most exporters lacked laboratory } \\
\text { facilities } \\
\text { Some processing facilities in need of } \\
\text { up-grading }\end{array}$ \\
\hline Human capital & $\begin{array}{c}\text { Need for training or retraining of } \\
\text { inspection and enforcement } \\
\text { personnel }\end{array}$ & Missing & $\begin{array}{c}\text { Need for quality assurance personnel } \\
\text { Need for hygiene training amongst } \\
\text { workforce }\end{array}$ \\
\hline $\begin{array}{l}\text { Capacity-building/ } \\
\text { Up-dating }\end{array}$ & $\begin{array}{l}\text { Many procedures and facilities out- } \\
\text { dated with little or no attempt to } \\
\text { build capacity and keep up-to-date }\end{array}$ & Missing & $\begin{array}{c}\text { Lack of co-operation/co-ordination } \\
\text { between exporters } \\
\text { Lack of training/professional up- } \\
\text { dating }\end{array}$ \\
\hline Communication & $\begin{array}{l}\text { Lack of communication between } \\
\text { government agencies } \\
\text { Lack of communication between } \\
\text { government and industry }\end{array}$ & Missing & $\begin{array}{l}\text { Lack of communication between } \\
\text { government and industry and within } \\
\text { the processing sector }\end{array}$ \\
\hline
\end{tabular}


One of the major weaknesses in food safety capacity was on fishing vessels and landing beaches. Fishing was mainly undertaken in small wooden craft with no facilities for cold storage to permit early chilling. However, some beaches (for example Port Victoria and Usenge) had begun to utilise collector vessels with insulated boxes. At landing beaches fish were often put directly onto the beach or floor of the banda, although some beaches did use metal barrows. There were rarely any facilities for prolonged chilling. The supply of potable water was frequently inadequate and toilets and hand washing facilities with soap were scarce. Transport of fish from beaches was usually in insulated trucks with ice. However, the ice was not always clean and other items (for example tyres and boots) were often carried with raw fish. Proper sandwiching of the fish and ice was not always undertaken.

A number of industrial fish processing facilities were in need of fundamental structural change and/or improvements, for example to permit segregation of processing operations. Further, there was a need for better training of food handlers in basic hygiene procedures and the employment of effective supervisory and quality management personnel.

The inefficacy of food safety controls for fish and fishery products in Kenya reflected prevailing capacity constraints in both the private and public sectors (Table 4). Further, the lack of any cooperation or co-ordination within the industrial fish processing sector meant that collective private sector capacity was missing altogether. The overall picture was of a long-established system that had not been upgraded in line with the growth in exports and was unable to implement effective controls within the context of rapidly evolving food safety standards in its major markets. Thus, both the public authorities and the supply chain were in a continuous position of problem-solving rather than strategic planning for the enhancement of capacity. Indeed, it is probably quite remarkable that product safety problems had not been experienced much sooner!

\subsection{Economic importance of the Kenyan Nile perch fishery}

Lake Victoria has always been Kenya's most significant fisheries resource, accounting for over half of all fish landings even in the 1970s. However, the wholesale shift in the scale of the fishery as a result of the development of Nile perch meant that by the mid-1990s it accounted for over 95 percent of both freshwater and total fish landings (Gitonga et al., 2002). This reflected the fact that, whilst the volume of fish landed at the Kenyan shores of Lake Victoria increased significantly during the 1980s and 1990s (see Figure 10), there was no comparable increase in the level of exploitation of Kenya's other fisheries resources, namely other freshwater areas and its marine waters.

In both nominal and real terms, the value of fish landed from Lake Victoria increased significantly through the 1980s and 1990s (Figure 10). Economically, the Lake Victoria fishery was largely insignificant at the start of the 1980s. However, in 1992 the value of fish landed peaked at US\$98 million (US\$160 million at constant 1995 prices). Subsequently, the landed value of fish declined to a steady level of around US\$ 60-70 million through the mid-1990s.

The value of output of the fisheries sector as a whole increased significantly through the early and mid-1990s, from US\$30 million in 1991 to US\$53 million in 1996. At constant 1995 prices, 
the value of output grew at an average rate of over five percent per annum. Simultaneously, the Lake Victoria fishery was increasingly dominated by Nile perch. In 1990, Nile perch accounted for 44 percent of the landed volume of fish (Figure 11). By 1996 this had increased to 58 percent.

The dominance of Nile perch in the Lake Victoria fishery both reflects and induced an increase in the landed price of Nile perch relative to other fish, in particular tilapia ${ }^{25}$. Historically the difference in landed price of Nile perch, tilapia and R. argentea (Omena) was not significant. However, in the mid-1990s the price of Nile perch increased significantly, whilst the price of tilapia actually declined.

The increase in landed price of Nile perch in the mid-1990s further enhanced its dominance within the economy of the Lake Victoria fisheries. By 1996, Nile perch accounted for over 75 percent of the landed value of fish in Kenyan waters of Lake Victoria. Indeed, the economic sustainability of the fishery at its current scale is largely dependent on Nile perch. There is limited scope for any shortfalls in the returns from Nile perch to be off-set by increased landings of other species.

\section{Figure 10. Nominal and real (constant 1995 prices) value of fish landings from Lake} Victoria, 1980-2002):

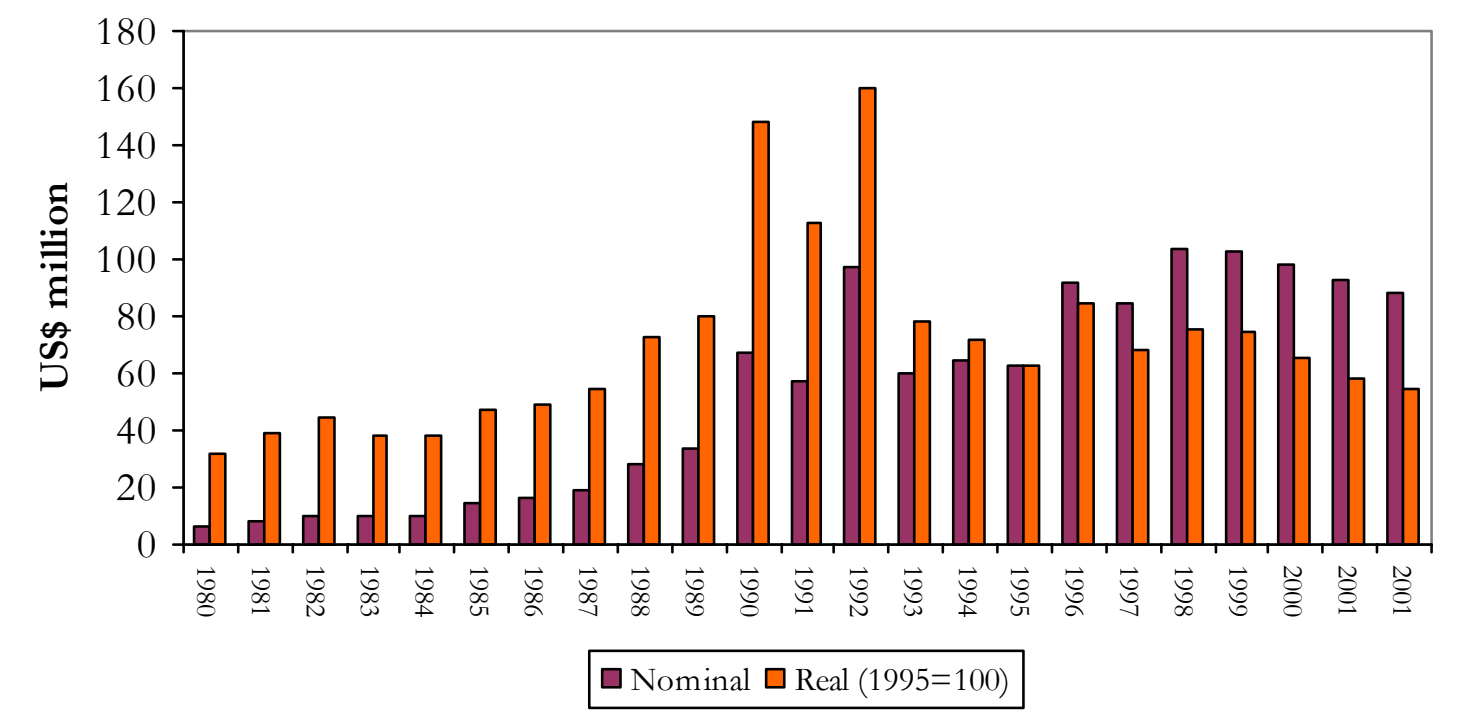

Note: calculated using IMF GDP deflator for Kenya (1995=100).

Source: $C B S$

Despite its small contribution to national GDP, the Nile perch fishery plays a significant role in the economy of the region bordering Lake Victoria. Nyanza is a region of economic and social under-development, both within a Kenyan and a wider African context. It has a Human Development Index (HDI) of only 0.440 and a Gender Development Index (GDP) of 0.434, both

\footnotetext{
${ }^{25} \mathrm{R}$. argentea and Nile perch are products of, in effect, separate fisheries and so do not directly compete with one another
} in terms of the direction of the fishing effort. 
significantly below the average for Kenya as a whole. The Human Poverty Index (44.3\%) for Nyanza is amongst the highest in Kenya. It is estimated that over 240,000 people in the coastal areas of Nyanza were directly or indirectly employed by the fishery in 1995 (Figure 12).

It is widely acknowledged that aggregate income increased significantly within the Lake Victoria fishery as a whole through the 1980s and 1990s (Reynolds and Greboval., 1989; Greboval and Mannini, 1992; Harris et al., 1995; Namisi, 2000). The fishery also supports a range of support sectors, for example vessel construction and repair and fishing equipment manufacture. Thus, it has been estimated that the total economic benefit of the fishery at the end of the 1990s was around KSh7.21 billion (US\$91.8 million) (Bokea and Ikaiara, 2000) ${ }^{26}$.

Figure 11. Landed volume of fish in Kenyan waters of Lake Victoria by species, 1990-2002:

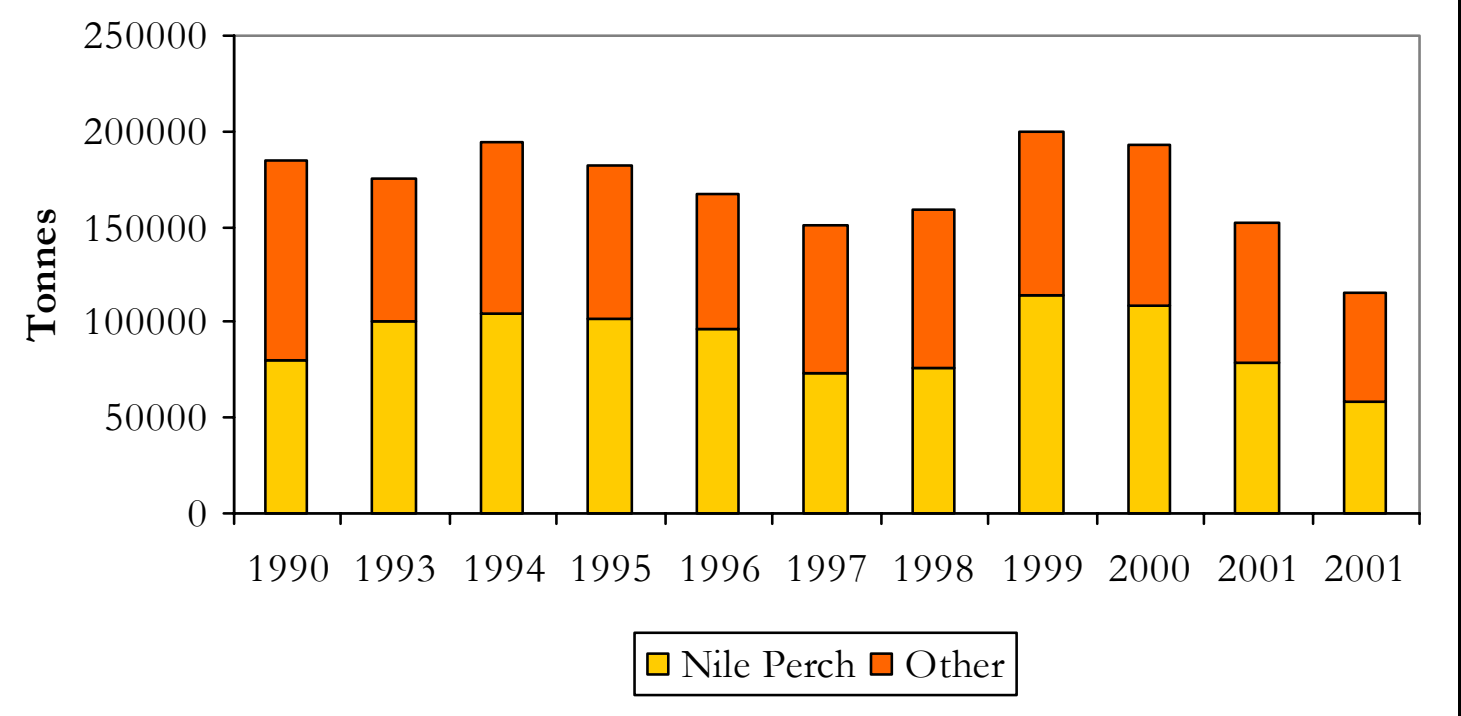

Source: Fisheries Department.

Although infrastructure remains poorly developed in the region bordering the Kenyan shore of Lake Victoria, there have been some improvements as a direct result of the Nile perch fishery. Most notably, feeder roads to main beaches have been established or improved in order that industrial processing facilities can source from remote landing sites (Harris et al., 1995). In turn, this has permitted access to other vehicles, including public transport and perhaps ironically, afforded greater access to local markets.

The expansion of the Nile perch fishery initially had a dramatic impact on the productivity of the fishing effort in Kenyan waters of Lake Victoria. Thus, the catch per unit effort (CPUE) increased from seven tonnes per boat in the late 1970s to around 30 tonnes per boat in 1991 (Figure 13) (Reynolds et al., 1995) However, more recently, the expansion in the number of

\footnotetext{
26 Whilst aggregate measures suggest the economic benefits of the Nile perch fishery have been considerable, there is much less consensus on the distribution of this additional income and the extent to which the communities have benefited $^{26}$. It is suggested that the significant income from the fishery quoted in official documents is not reflected in the lifestyles of the local fisher-folk (Jansen, 1997; Ong'ang'a, 2002).
} 
people actively engaged in the fishery combined with lower catches has made fishing an increasingly burdensome source of livelihood. Thus, fishers are required to spend increasing amounts of time away from the home landing in order to secure an adequate catch and to avoid theft of fish and/or equipment (Harris et al., 1995). For example, whilst less than five hours on average was spent fishing each day in the early 1980s, this had increased to 12 hours by 1994 (Geheb and Binns, 1997). Indeed, the CPUE has been in decline since 1991 and by 2000 was back down to the same level as in 1985.

The development of industrial fish processing facilities has had a profound impact on artisanal processing activities based one or near the landing beaches. Whilst around 2,400 jobs have been created in the factories, it is estimated that over 15,000 people were previously employed in artisanal processing, including sun-drying and smoking (Abila and Jansen, 1997). Further, employment in the industrial processing sector occurs mainly in urban areas, around Kisumu and Nairobi, and thus does not benefit the local fishing communities.

Figure 12. Number of people directly and indirectly employed by Lake Victoria fishery, 1971-2000:

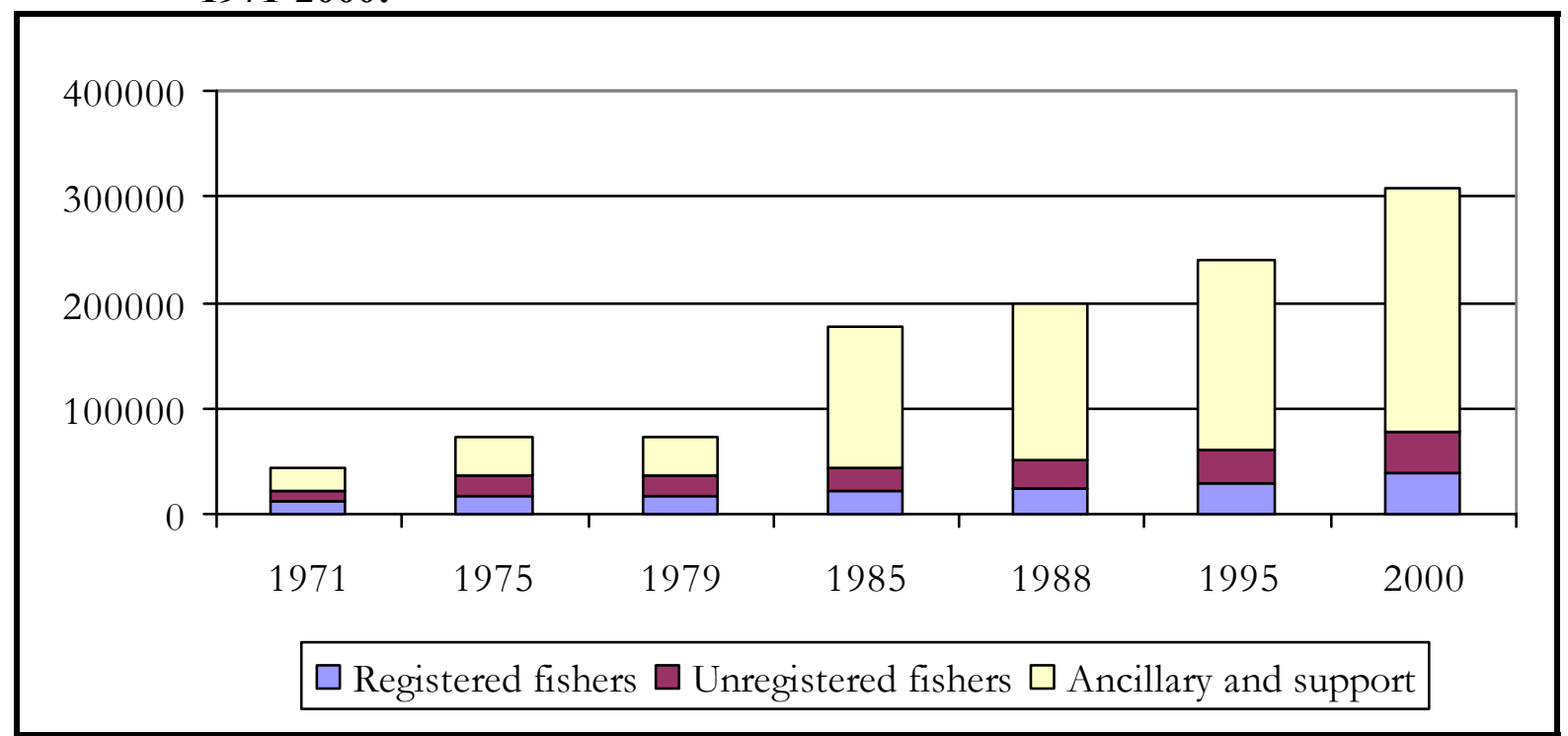

Note: Own calculations. 
Figure 13. Catch per unit effort in Kenyan waters of Lake Victoria, 1979-2000:

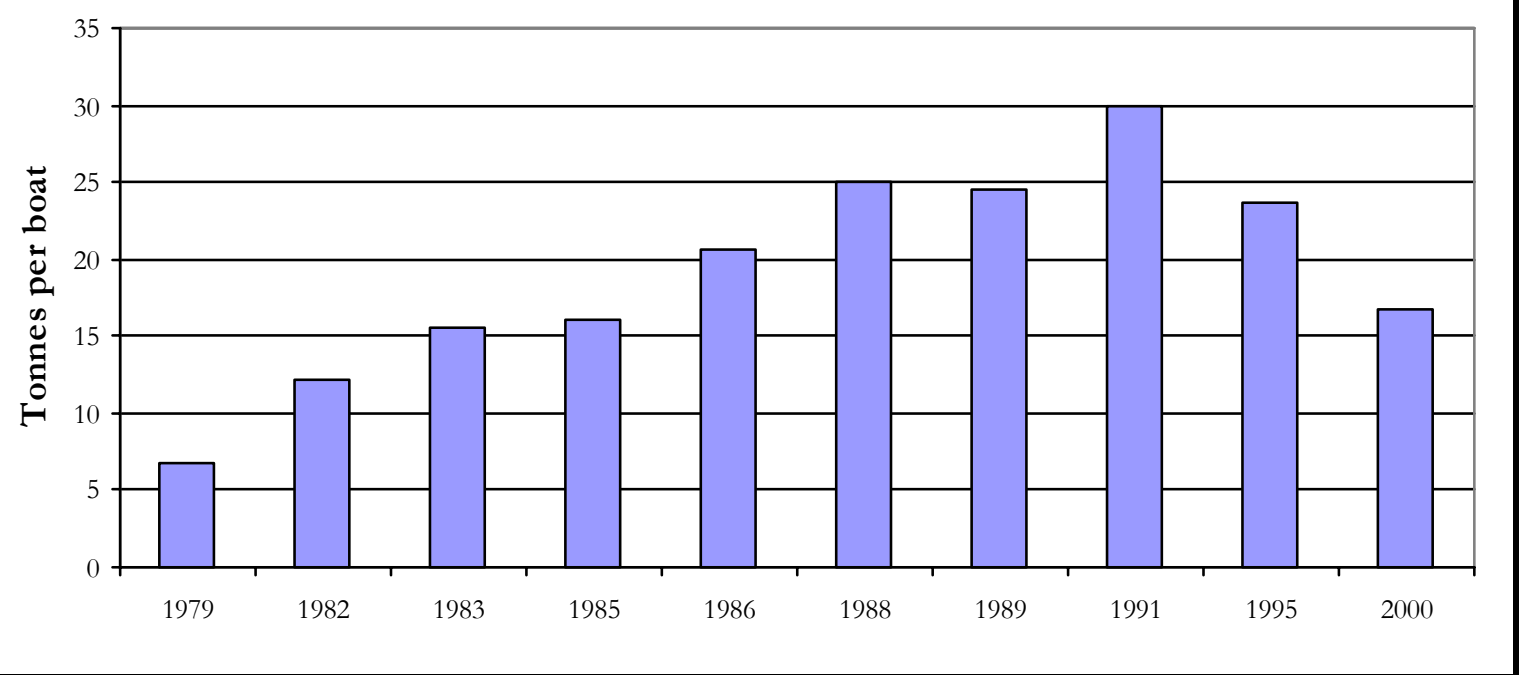

Source: Own calculations

Traditionally, almost all animal protein eaten by the communities surrounding Lake Victoria was derived from the lake, although in recent years fish consumption has been in decline. Abila (2000) suggests that this is the direct result of the Nile perch fishery that has resulted in reduced access to fish by lakeside consumers. Abila and Jansen (1997) estimate that 48 percent of all Nile perch landed is sold to the industrial fish processors and that the only Nile perch available to the local population is either small juvenile fish and/or fish rejected by the industrial processors. Further, the demand for fish from the export supply chain has driven up prices beyond the means of low much of the local population.

Questions have been raised about the long-term sustainability of the Nile perch fishery. For example, Jansen (1997) and Goulding (1997) argue that the Nile perch fishery is leading to a decline in the resources of the Lake and threatens food security of local people. On the one hand, investment in excess processing capacity has generated an almost 'unlimited' demand for raw fish. On the other, since 1991 the landed catch of Nile perch has been in decline despite a continued increase in the total fishing effort (Bokea and Ikiara, 2000; McCormick and Mitullah, 2002). Simultaneously, the average size of fish has diminished and processors have been forced to accept smaller and smaller fish in order to maintain throughput ${ }^{27}$. In turn, over-fishing and use of illegal fishing gear are now widespread ${ }^{28}$. This has been further exacerbated by the proliferation of water hyacinth that has rendered the Lake inaccessible to some landing beaches.

\section{EXPORT PERFORMANCE TO 1996}

This section reviews the evolution of the Nile perch sector in Kenya to the end of 1996. In so doing it provides an overview of the development and state of the sector when restrictions were

\footnotetext{
${ }_{27}$ Previously or at the beginning of Nile perch trade, only fish exceeding $2-3 \mathrm{Kg}$ (and typically up to $200 \mathrm{Kg}$ ) were accepted for processing. Today, at times, processors accept fish under $1 \mathrm{Kg}$. Virtually all good quality fish exceeding $2 \mathrm{Kg}$ is supplied to the industrial processing sector.

${ }^{28}$ Whilst regulations are in place, these are poorly enforced and rates of non-compliance are high.
} 
first imposed on exports to the Spain and Italy at the end of 1996, and then to all Member States in mid-1997.

Through the 1980s and 1990s the Lake Victoria fishery became almost entirely export-oriented. Furthermore, the scope of the supply chain progressively extended beyond regional markets to industrialised countries across the globe. In turn, this brought about a significant expansion in total fish and fishery product exports from US\$1.4 million in 1985 to a peak of US\$51.8 million in 1996. However, despite impressive rates of growth, the fisheries sector continues to account for a relatively small proportion of total exports, averaging around 2.5 percent through the $1990 \mathrm{~s}$, particularly in comparison with major exports such as horticultural products ${ }^{29}$, tea and coffee.

Until the later 1980s, exports of Nile perch were negligible. The expansion of the Lake Victoria fishery was largely directed at supplying local markets and trade within regional markets, much of which was 'undocumented'. International trade in Nile perch became established in the mid1980s and expanded rapidly through to the mid-1990s. Thus, the volume of exports increased from 102 tonnes in 1985 to a peak of 19,300 tonnes in 1994 (Figure 14). Simultaneously, the price of Nile perch increased on international markets, thus the value of exports increased from US\$0.1 million in 1985 to US\$43.9 million in $1996^{30}$. By the mid-1990s, Nile perch accounted for up to 90 percent of total fish and fishery product exports from Kenya (Bokea and Ikaiara, 2000).

Figure 14. Volume and value of Nile perch exports from Kenya, 1985-1996:

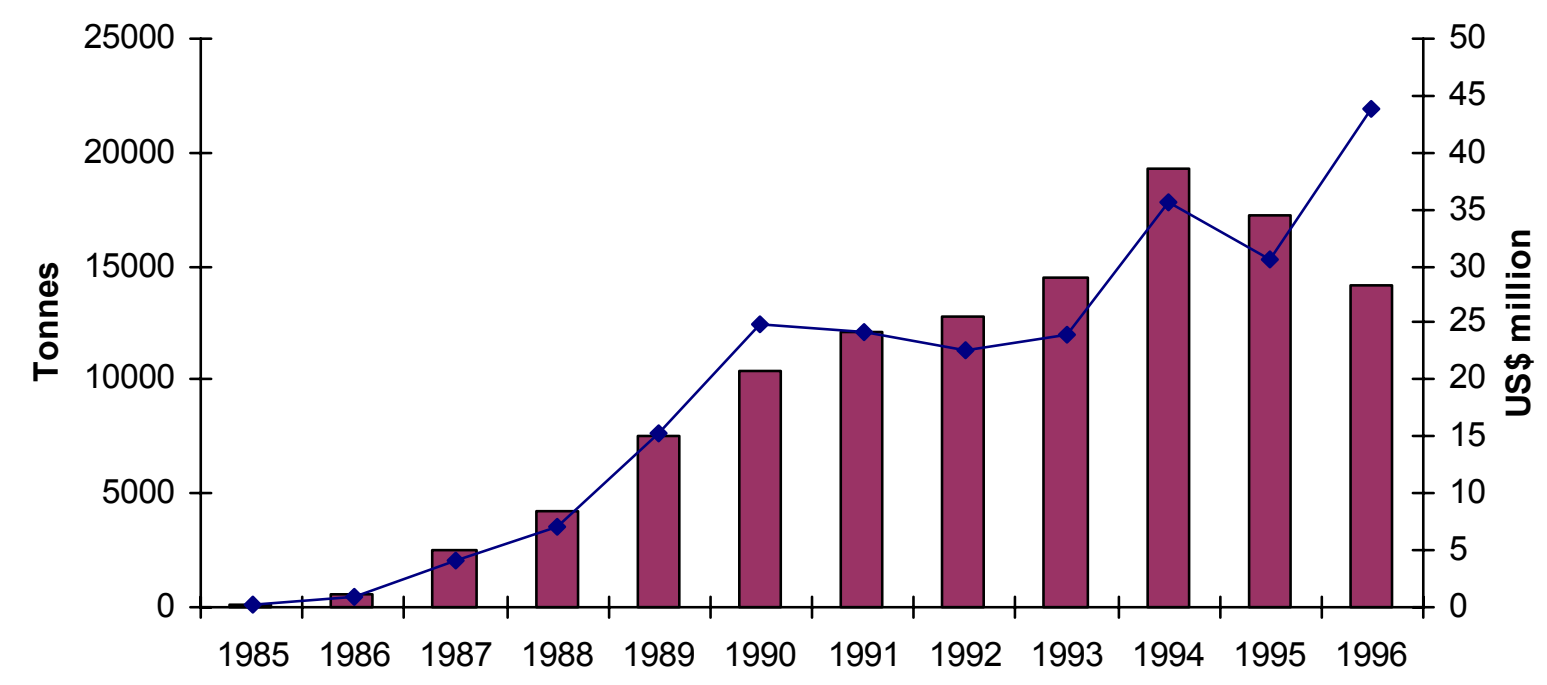

Source: $C B S$

Through to the mid-1980s, Kenya was unable to satisfy fully the domestic demand for fish and was a net importer (Bokea and Ikaiara, 2000). However, the expansion of fisheries production

\footnotetext{
${ }^{29}$ For a discussion of horticultural exports from Kenya and the role of food safety and other standards see jaffee (2003).

${ }^{30}$ Bokea and Ikaiara (2000) suggest that there is significant under-reporting of fish sales and exports to evade tax. Estimates of the degree of under-reporting range from 20 to 29 percent.
} 
has meant that, since the last 1980s, Kenya has had a positive balance of trade in fish and fishery products. For example, over the period 1980 to 1996 a trade deficit of US\$3.2 million was converted to a trade surplus of US\$53 million.

In addition to exports of fish fillets, there is a low volume but very lucrative trade in fish maws that are dried and exported in China and Japan (Bokea and Ikaiara, 2000). In 1995, the value of exports was US $\$ 0.29$ million. In the absence of this trade, Nile perch maws would have very little value as an input to isinglass production.

During the early and mid-1990s, the EU was the dominant market for Kenyan exports of fish and fishery products (Table 5). For example, in 1996 the EU accounted for around 65 percent of fish filet exports. The Netherlands alone accounted for over 28 percent of exports. Germany, Greece and Spain were other major EU markets. The most significant non-EU markets were Israel, accounting for 21 percent of exports, and Japan.

Exports of fish fillets can be divided into two closely-related sub-sectors. Frozen fillets typically account for over 93 percent of fish fillet exports but have a lower unit value than fresh and chilled fillets. Over the period 1995 to 1996, however, the price differential declined dramatically from over 100 percent to 20 percent.

Through the 1990s, the dominant market for Kenyan exports of fresh and chilled fish fillets was the EU. Kenya has very good air freight connections with a number of major European cities, including London, Amsterdam, Rome and Frankfurt. Further, the price of chilled and fresh fillets in the EU is up to 20 percent greater than in other markets. Major EU markets included the Netherlands, Germany and Belgium. 
Table 5. Exports of fresh, chilled and frozen fish fillets by destination, 1994-1996 (tonnes):

\begin{tabular}{|c|c|c|c|}
\hline Country & $\mathbf{1 9 9 4}$ & $\mathbf{1 9 9 5}$ & $\mathbf{1 9 9 6}$ \\
\hline Israel & 3771 & 3034 & 3431 \\
\hline Netherlands & 3389 & 2453 & 4485 \\
\hline Singapore & 2300 & 530 & 1029 \\
\hline Greece & 1950 & 975 & 1105 \\
\hline Spain & 1174 & 568 & 1035 \\
\hline Germany & 1041 & 956 & 1510 \\
\hline Australia & 854 & 181 & 221 \\
\hline Italy & 443 & 339 & 17 \\
\hline France & 420 & 385 & 439 \\
\hline Belgium & 314 & 576 & 274 \\
\hline Hong Kong & 271 & 84 & 61 \\
\hline United Kingdom & 248 & 858 & 573 \\
\hline USA & 241 & 802 & 261 \\
\hline Portugal & 123 & 613 & 597 \\
\hline Japan & 44 & 724 & 674 \\
\hline Other & 497 & 817 & 265 \\
\hline TOTAL & $\mathbf{1 3 8 9 3}$ & $\mathbf{1 5 9 7 4}$ & $\mathbf{1 7 0 7 9}$ \\
\hline
\end{tabular}

Source: $C B S$ (2002).

Historically, the EU has also been the major market for Kenyan exports of frozen fish fillets, accounting for around 60 percent of exports in 1996. Close proximity and well-established connection, translating into lower sea freight costs, combined with higher prices for Nile perch have made EU countries an attractive market. However, the export market base is far more diverse than for fresh and chilled fillets. Indeed, there is much greater flexibility to divert exports between alternative markets.

\section{HYGIENE STANDARDS AND RESTRICTIONS ON EXPORTS TO THE EUROPEAN UNION}

It is evident that a number of countries, including well-established exporters of fish and fishery products, have struggled to comply with the EU's standards on hygiene in the processing, transport and marketing of fish. Thus, whilst the number of countries achieving Part I status increased from 27 in April 1997 to 83 in December 2003, 26 remain in Part II and face the possibility of being excluded from EU markets unless they achieve compliance by the end of 2005. More positively, however, more than half of the Part I countries are low or lower middleincome, including a number of low-income African countries (Figures 15 and 16). 
Figure 15. Countries approved to export fish and fishery products to the European Union by income group, December 2003:

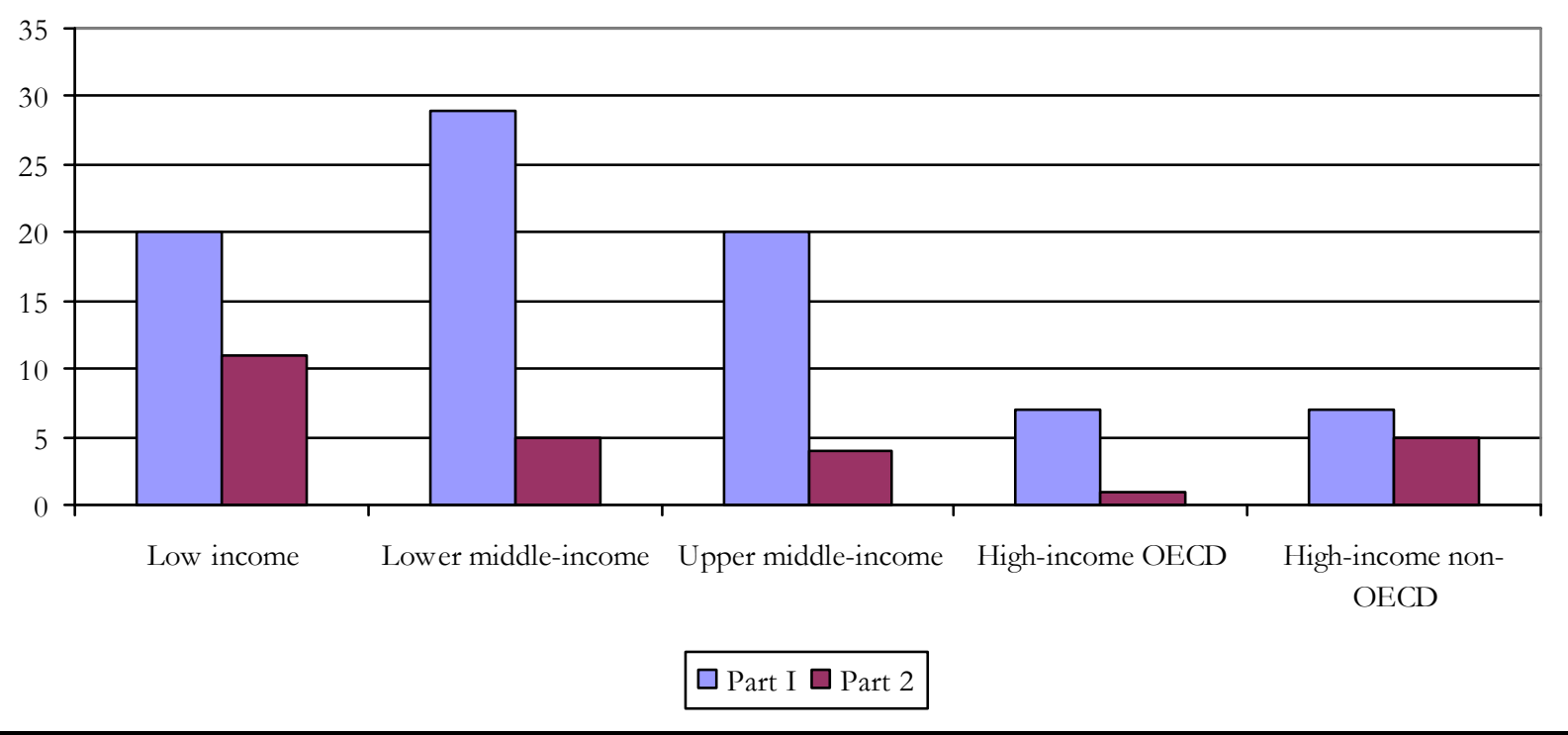

A number of countries have been excluded from Part II, and thus are prohibited from exporting to the EU, following inspection by the European Commission. Examples are St Vincent and the Grenadines and Cape Verde. Others, including Guinea-Bissau, St Lucia, Congo Brazzaville and the Former Yugoslav Republic of Macedonia, were not able to demonstrate equivalent conditions when the provisions for bilateral trade with individual EU Member States (List II) were removed at the end of 1999, and have still not achieved even Part II status.

Other countries have faced temporary restrictions on exports of fish and fishery products to the EU. These include India, Bangladesh, Vietnam, Mozambique, Tanzania, Uganda and Kenya. In certain cases major non-conformities have been identified during inspections by the European Commission. In others, microbiological contamination had been detected through border inspection. 
Figure 16. Countries approved to export fish and fishery products to the European Union by region, December 2003:

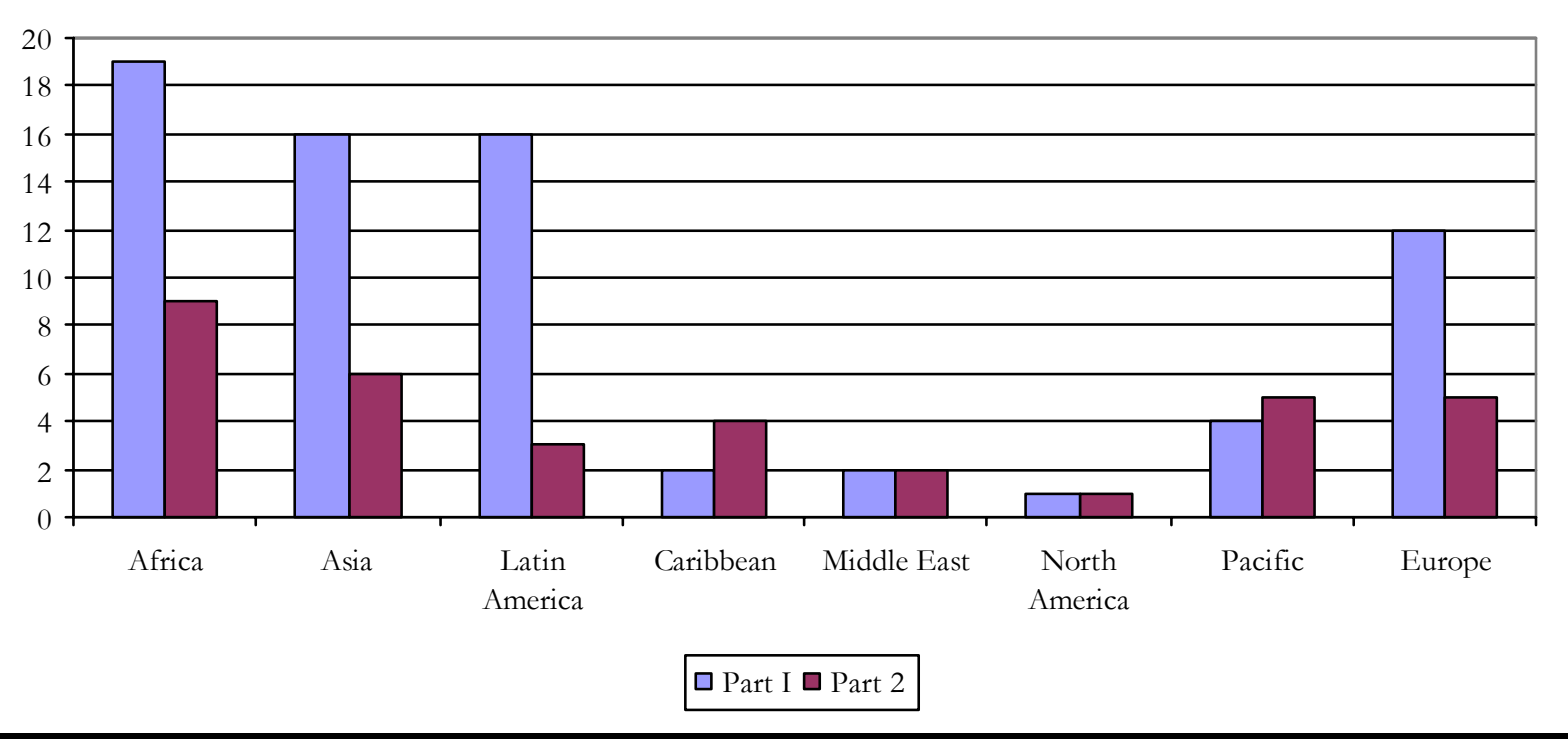

Kenya provides a case study of a country that experienced significant problems achieving compliance with EU hygiene standards. Further, from late 1996 through to the end of 2000, Kenya faced prolonged periods during which restrictions were imposed on fish, and Nile perch in particular, to the EU (Table 6). For much of this time restrictions were also imposed on exports from Tanzania and Uganda, and for a limited period, also Mozambique.

Table 6. Summary of food safety restrictions on Kenyan fish exports to the European Union:

\begin{tabular}{|c|c|c|}
\hline Dates & Restrictions & $\begin{array}{c}\text { Products/ } \\
\text { Regions }\end{array}$ \\
\hline $\begin{array}{c}\text { 27 November 1996-3 } \\
\text { April 1997 }\end{array}$ & $\begin{array}{c}\text { Exports prohibited to Spain } \\
\text { and Italy }\end{array}$ & Nile perch \\
\hline $\begin{array}{c}\text { 4 April 1997 - 30 June } \\
1998\end{array}$ & $\begin{array}{c}\text { Border testing of all } \\
\text { consignments for } \\
\text { Salmonella }\end{array}$ & Nile Perch \\
\hline 23 December 1997 - & Exports prohibited to EU & Fresh fish \\
\cline { 2 - 3 } 30 June 1998 & $\begin{array}{c}\text { Border testing of all } \\
\text { consignments for Vibrio } \\
\text { cholerae and Vibrio } \\
\text { parahaemoliticus }\end{array}$ & $\begin{array}{c}\text { Frozen/processed fish not } \\
\text { caught at sea and directly } \\
\text { landed to EU }\end{array}$ \\
\hline 12 April 1999- & Exports prohibited to EU & Fish from Lake Victoria \\
\hline
\end{tabular}

Towards the end of 1996 Salmonella was detected in a number of consignments of Nile perch from Kenya, Tanzania and Uganda, most notably in Spain. As a result, the Spanish government imposed a prohibition on imports of Nile perch from Kenya, Tanzania and Uganda on 27 
November 1996. The Italian Government soon followed suit (Mitullah, 1998). Subsequently, on 4 April 1997 the European Commission introduced a requirement for Salmonella testing of all consignments of Nile perch from the region ${ }^{31}$. Imports were subject to positive release, whereby they were held at the border until test results confirmed that the consignment was free of Salmonella. This requirement was initially applied for a limited period to 30 June 1997, but was subsequently extended to 30 June $1998^{32}$. The cost of the tests was borne by the importer.

During the second half of 1997, there was an outbreak of Cholera across East Africa largely associated with the heavy rains brought by El Nino. The European Commission had on-going concerns about the efficacy of food safety controls in Kenya, Tanzania and Uganda based on the results of inspections and the detection of Salmonella of consignments of Nile perch. Thus, on 23 December 1997 it introduced a requirement for testing of all consignments of frozen fish from Kenya, Mozambique, Tanzania and Uganda for Salmonella, Vibrio cholerae and Vibrio parahaemoliticus $^{3334}$. The cost was covered by the importer. Further, given the time taken for these tests to be undertaken, imports of fresh fish were prohibited. The requirement for Salmonella and Vibrio cholerae testing of marine fish was lifted on 16 January 1998. On 30 June 1998, all requirements relating to border testing of fish from these countries were rescinded. Instead, the Competent Authority in each country was required to provide a declaration with each consignment (as part of the standard veterinary health certificate) that all persons handling fish and fishery products had undergone medical checks.

There was quite widespread criticism of the EU's prohibition on exports of fresh fish from the region, most notably from the World Health Organisation (WHO). Indeed, the WHO raised the issue at the WTO SPS Committee (WTO, 1998a):

"....although there is a theoretical risk of cholera transmission with international food trade, the weight of the evidence suggests that this risk is very small and can normally be dealt with by means other than an embargo on importation."

Further, the WHO suggested that it would have been better to deal with these concerns through agreements on good hygiene practice for handling and processing of fish aimed at preventing, eliminating or minimising the risk of any potential contamination. The European Commission responded that, the inspections it had undertaken of food safety controls in these countries had identified significant deficiencies and that, once proper safeguards and modifications had been put in place, the EU would accept these procedures as an alternative to the ban on imports of fresh fish and border testing of frozen fish (WTO, 1998b).

During the period July 1998 to March 1999, no specific restrictions were applied to Kenyan exports of Nile perch and other fish and fishery products. However, in March 1999 a suspected case of fish poisoning with pesticide was identified in Uganda. The Ugandan authorities responded by suspending all exports on 22 March 1999. The Kenyan and Tanzanian

\footnotetext{
${ }^{31}$ Commission Decision 97/272/EC.

32 Commission Decision 97/458/EC.

${ }_{33}$ Commission Decision 97/878/EC.

34 A requirement for Vibrio cholerae testing of fruits and vegetables was also applied for the period February to October 1998.
} 
governments took precautionary measures but did not suspend exports. In Kenya, the Fisheries Department imposed a two week ban on fishing and trading of Lake Victoria fish and implemented monitoring of water, sediment and fish according to a defined sampling plan (Fisheries Department, 2001a; 2001b). Further, the local community was made aware of the issue through meetings and seminars and community-based vigilante groups were established to ensure compliance. However, given that exports were not suspended and that fish from neighbouring-country waters was known to be landed in Kenya and Tanzania, the EU imposed a ban on exports of fresh and frozen Nile perch on 12 April $1999^{35}$.

The length of time for which exports of Nile perch to the EU were prohibited varied significantly across the three countries. The EU undertook inspections in Tanzania towards the end of 1999 and subsequently the restrictions were lifted on 31 January 2000, subject to a declaration in the standard veterinary health certificate that the product had been produced under monitoring checks for environmental contaminants such as pesticides. ${ }^{36}$ Inspections were undertaken in Uganda in mid-2000 and the restrictions were lifted, subject to a comparable declaration on 4 August $2000 .^{37}$ In the case of Kenya, however, restrictions were not lifted until 1 December $2000 .^{38}$

These specific restrictions on exports of fish and fishery products to the EU have taken place within a broader program of inspections of hygiene controls in Kenyan by the European Commission. Over the period 1991-2001 a total of five inspection visits have taken place ${ }^{39}$. Indeed, Kenyan was not included in List II until January 1999 and has yet to achieve full compliance and thus achieve List I status. This contrasts with Tanzania and Uganda, which were added to List I in July $1998^{40}$ and August $2001^{41}$ respectively.

When the European Commission undertook inspections in Kenya in 1998 it found that, despite major improvements having been made in the light of previous inspection reports, significant deficiencies remained (European Commission, 1998). Concerns related to the inspection and approval of processing facilities, some of which were considered not to comply with EU hygiene standards, hygienic conditions at landing beaches, laboratory infrastructure, and use of identification marks on consignments of fish for export (Table 7).

The European Commission undertook a further inspection visit in 1999 to assess the efficacy of controls on pesticides in the light of the restrictions in place on exports of Nile perch to the EU at that time (European Commission, 1999). Whilst concerns were raised about the monitoring and sampling programs that had been implemented by the Kenyan authorities, the most significant weakness related to laboratory infrastructure (Table 8). Whilst the laboratory of the Kenya Plant Health Inspection Services (KEPHIS) was considered generally acceptable, the facilities and methods of analysis employed at the laboratory of the Government Chemist were considered

\footnotetext{
${ }^{35}$ Commission Decision 99/253/EC.

36 Commission Decision 2000/127/EC.

${ }^{37}$ Commission Decision 2000/493/EC.

38 Commission Decision 2000/759/EC.

39 Two in 1997 and one each in 1998, 1999 and 2001. Inspection reports for the two missions in 1997 are not publicly available.

${ }^{40}$ Commission Decision 98/422/EC.

${ }^{41}$ Commission Decision 2001/633/EC.
} 
inadequate, such that results communicated to the European Commission could not be considered accurate and reliable.

Table 7. Problems identified in European Commission inspection, November 1998:

\begin{tabular}{|c|c|}
\hline Issue & Details \\
\hline Inspection recording & $\begin{array}{l}\text { - Insufficient recording of monitoring of 'own checks' } \\
\text { by fish processing facilities }\end{array}$ \\
\hline Fisheries inspectors & $\begin{array}{l}\text { - Lack of expertise and technical direction to undertake } \\
\text { a thorough inspection of processing facilities with } \\
\text { properly documented records } \\
\text { - Generally insufficient training and experience } \\
\text { - Lack of confidence in enforcement }\end{array}$ \\
\hline Identification marks & $\begin{array}{l}\text { Lack of identification marks on individual boxes of } \\
\text { product destined for export to the EU }\end{array}$ \\
\hline Processing facilities & 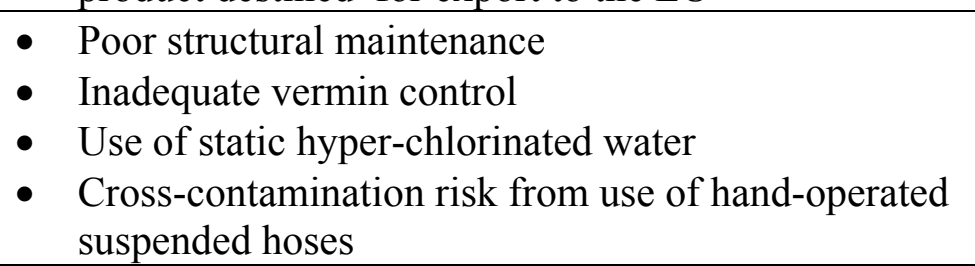 \\
\hline Laboratory facilities & $\begin{array}{l}\text { - Poor level of maintenance } \\
\text { - Inadequate cleaning standards } \\
\text { - Lack of temperature control } \\
\text { - No facilities to undertake chemical analysis } \\
\text { - No facilities to undertaken total plate count at } 22^{\circ} \mathrm{C}\end{array}$ \\
\hline Landing sites & $\begin{array}{l}\text { - } \text { Unhygienic storage of fish on vessels } \\
\text { - } \quad \text { Lack of potable water } \\
\text { - } \quad \text { Lack of perimeter fence able to exclude general } \\
\text { public, vermin and stray animals }\end{array}$ \\
\hline
\end{tabular}

Source: European Commission (1998).

In March 2002, a European Commission mission again visited Kenya, both for the purpose of assessing compliance with EU hygiene standards with a view to inclusion in List I and monitoring measures relating to pesticide residues in fish (European Commission, 2003). The overall impression of the inspection team was positive, although some relatively 'minor' noncompliances were identified. In particular, the pesticide monitoring program that had been communicated to the European Commission by the Kenyan Government had not been fully implemented and improvements were required in procedures for laboratory analysis. Some nonconformities were identified in processing establishments, most of which had already been recognised by the Competent Authority although no action had been taken. Finally, hygienic conditions at landing sites were considered to be in need of improvement. The Kenyan Government provided written confirmation to the European Commission regarding the necessary 
improvements. Subsequently, special import conditions were laid down in December 2003 and Kenya was added to Part I. ${ }^{42}$

Kenyan exports of Nile perch to the EU present a rather complex and multi-layered illustration of the role of hygiene standards and provides a convenient comparison with the experiences of other countries and the efficacy of their attempts to achieve compliance. On the one hand, Kenya had struggled for some time to comply with EU requirements relating to hygiene in the processing and marketing of fish and fishery products. In part this reflects the lack of efforts to up-grade food safety controls in line with the growth in exports over a considerable period of time. On the other, it had faced a period during which exports of Nile perch to the EU were prohibited and otherwise restrictions were applied. Clearly, the two are not unrelated; the fact that the EU had identified deficiencies in the food safety controls applied in Kenya undoubtedly influenced the actions taken by the European Commission. However, Kenya's efforts were hampered by two events over which it had no control, namely an outbreak of Cholera and an incident of fish poisoning in Uganda.

Table 8. Problems identified in European Commission inspection, September 1999:

\begin{tabular}{|c|c|}
\hline Issue & Details \\
\hline Monitoring samples & $\begin{array}{l}\text { - Lack of records, for example on amount of sample in } \\
\text { relation to amount of landed fish }\end{array}$ \\
\hline Surveillance samples & $\begin{array}{l}\text { - Sample not sealed for transportation } \\
\text { - Lack of documentation on date, amount, kin and } \\
\text { - sender of sample } \\
\text { - Long transportation period to laboratory }\end{array}$ \\
\hline Laboratory facilities & $\begin{array}{l}\text { Laboratory of Government Chemist } \\
\text { - Poor conditions of hygiene and cleanliness } \\
\text { - } \quad \text { Potential for cross-contamination of samples } \\
\text { - } \quad \text { Analytical equipment in poor condition. No } \\
\text { registration or maintenance records } \\
\text { - Chemicals and standard solutions expired } \\
\text { - No quality control system in operation } \\
\text { - No accreditation or recognition } \\
\text { - Testing methods unsuitable for specific analyses and } \\
\text { Kenya Bureau of Standards } \\
\text { - No registration or maintenance records for equipment } \\
\text { - No written operating procedures } \\
\text { - No accreditation or recognition } \\
\text { - Chemicals and standard solutions expired } \\
\text { - Capacity limited in terms of range of active } \\
\quad \text { compounds that can be analysed }\end{array}$ \\
\hline
\end{tabular}

Source: European Commission (1999).

${ }^{42}$ Commission Decision 2004/39/EC; Commission Decision 2004/36/EC. 


\section{IMPACTS OF RESTRICTIONS ON EXPORTS TO THE EUROPEAN UNION}

This section focuses on the impact of the restrictions on exports to the EU from 1997 to 2001. In particular, it examines trends in the volume and value of exports, landings and price of Nile perch, and changes in the industrial fish processing sector over this period. Whilst it is evident that the restrictions had a significant and adverse effect on the Nile perch fishery, given that an econometric analysis is beyond the scope of the current paper, it is not possible to determine the extent to which the observed trends can be directly attributable to the loss of exports to the EU. However, it is also evident that the loss of Kenya's most important export market for Nile perch induced fundamental changes in the manner in which the supply chain operates and concerted efforts to enhance levels of hygiene and other food safety controls.

In assessing the effect of these restrictions at both a macro and micro level it is important to recognize the prevailing challenges facing the Nile perch fishery (Geheb and Binns, 1997). Thus the resultant 'shock' to the sector must be seen as one of a series of drivers that collectively have induced fundamental changes to the structure and modus operandi of the Nile perch supply chain (Mitullah, 1999). Further, the ability and ways in which the sector was able to respond reflected prevailing levels of capacity which, arguably, had not kept pace with the development of the sector and its progressive export orientation.

Towards the end of the 1990s, both total landings of Nile perch and average fish size stabilized and then began to decline, despite a significant increase in the total fishing effort. This created intense competition for fish at landing beaches as industrial fish processors, most of which were operating well below capacity, enhanced their efforts to secure a reliable supply of raw material. Thus, whilst lucrative markets had been developed in a number of industrialized countries, it was becoming increasingly difficult to satisfy demand.

Whilst the structure and modus operandi of the supply chain had changed fundamentally as it became increasingly export-oriented, most landing beaches remained undeveloped. Many lacked even the basic infrastructure required for the marketing of fish, for example a covered banda, cold storage facilities and running water. Further, efforts to engender effective management of both the beaches and local fishing communities had been largely ineffective. Where regulations and policies had been put in place, these were largely under-enforced. Along the supply chain, there was little or no cooperation within the industrial fish processing sector. Thus, the supply chain operated in a largely uncoordinated and laissez faire manner with little or no planning for its future evolution.

\subsection{Volume and value of exports}

As described in Section 6, a ban on exports of fresh fish from Kenya was applied by Spain and Italy in November 1996. At this time, these two countries accounted for 7.5 percent of fresh fish exports and 6.7 percent of total fish exports. In April 1997, restrictions began to be applied on exports to the EU as a whole. Initially, the European Commission introduced a requirement for the testing of all consignments of Nile perch for Salmonella. However, exports of fresh fish were banned altogether for the period January to June 1998, whilst frozen fish was subject to stringent microbiological testing requirements. Through this period, the volume of exports 
declined from 14,143 tonnes in 1996 to 10,881 tonnes in 1998 (Figure 17). Likewise, the value of exports diminished from US\$43.9 million in 1996 to US\$29.0 million in 1998 (Figure 18).

Figure 17. Volume of Nile perch exports, 1996-2002:

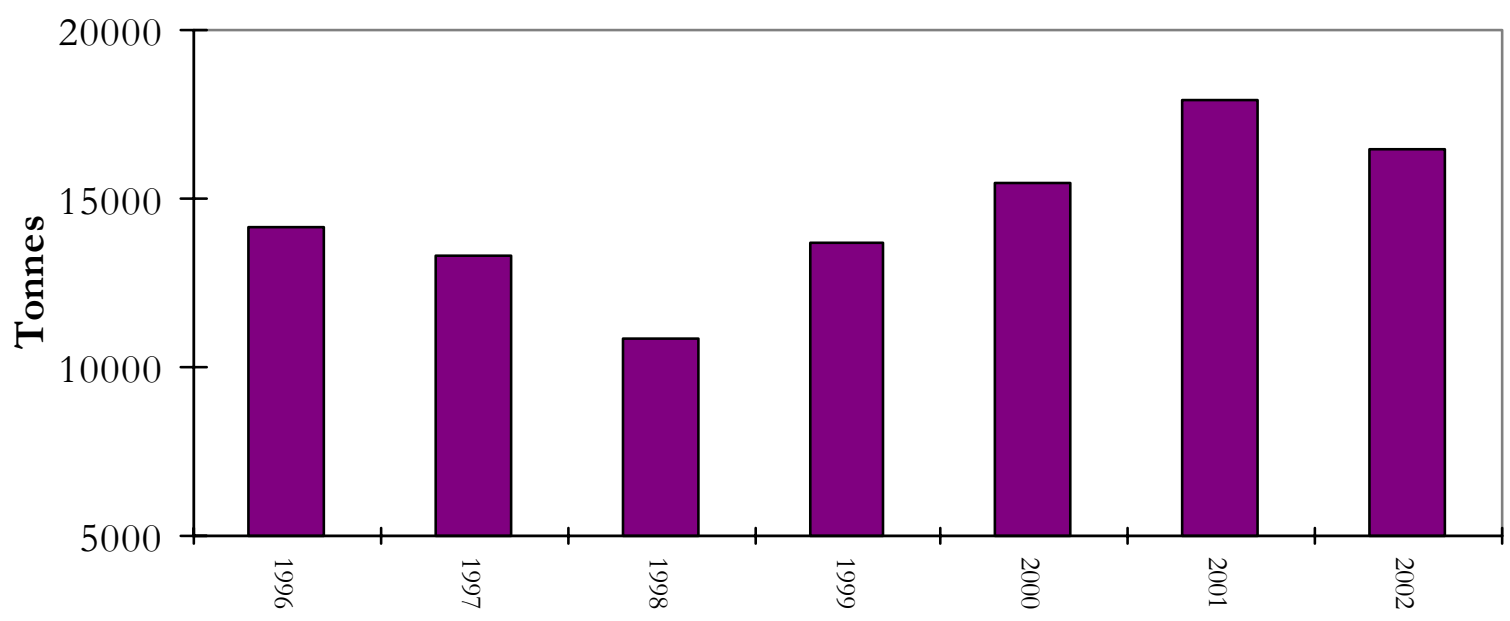

Source: Fisheries Department

Figure 18. Value of Nile perch exports, 1997-2001:

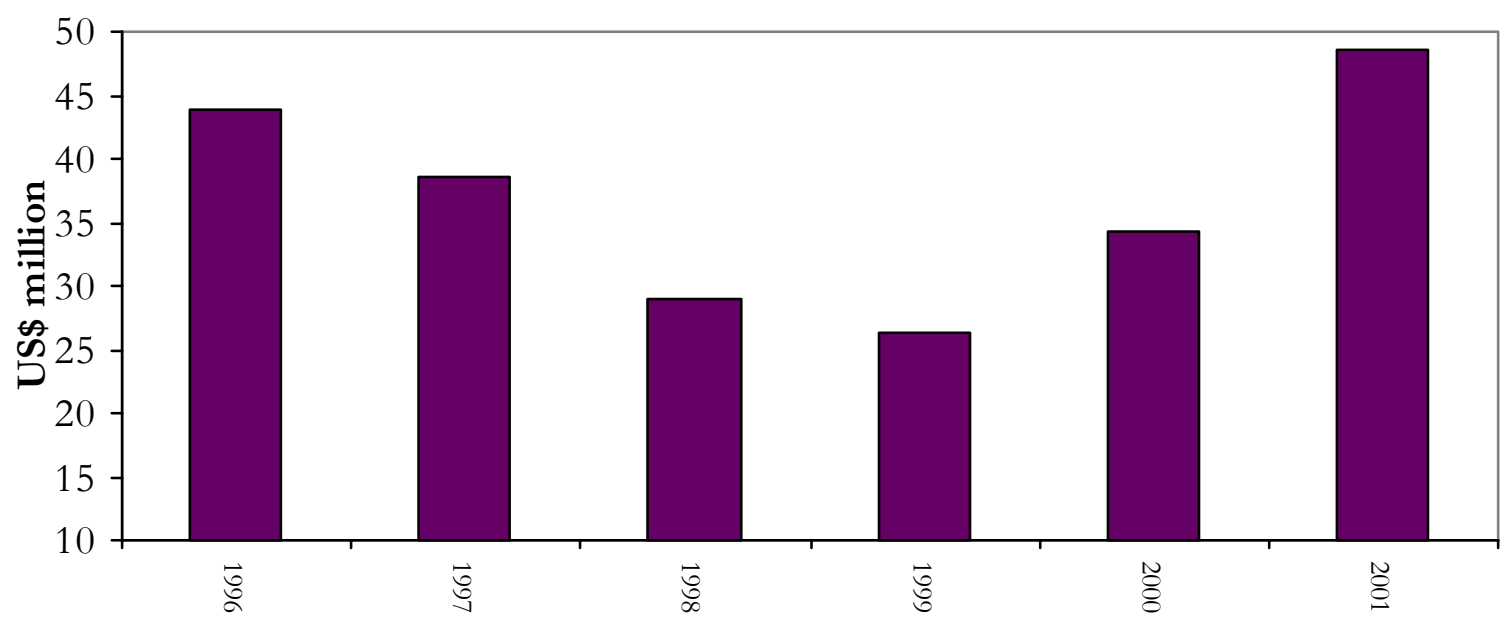

Source: Fisheries Department

The EU imposed further restrictions on exports of fish and fishery products from Kenya from April 1999 to December 2000, prohibiting all fish from Lake Victoria. Over this period, however, the volume of exports of Nile perch actually increased to 13,667 tonnes in 1999 and 15,438 tonnes in 2000 (Figure 17). However, the value of exports declined to US\$26.4 million in 1999, before recovering through 2000 to reach US\$34.2 million (Figure 18). This reflects the 
ability of Kenyan exports to exploit alternative but lower unit value markets for frozen Nile perch (see below).

Following the lifting of the restrictions, Kenyan exports of Nile perch increased significantly through 2001 to 17,900 tonnes valued at US\$48.5 million. However, in 2002 the volume of exports declined to 16,482 tonnes, largely reflecting on-going problems with the landed supply of Nile perch.

Kenyan exporters of Nile perch responded to the restrictions in the EU by exploiting alternative markets, including other industrialised countries such as Australia, USA, Japan and Hong Kong, as well as a number of middle-income countries in Latin America, Asia and the Middle East (Table 9). These exports were in the form of block frozen fish fillets that have a significantly lower price than fresh fillets (Figure 19). Exports of fresh fillets, at least initially, ceased altogether. Further, the price of frozen Nile perch fillets in these alternative markets was typically lower than that previously paid by EU buyers. As a consequence, the unit value of Nile perch exports declined through 1998 and 1999.

Figure 19. Unit value of Kenyan fish exports by type, 1997-2000:

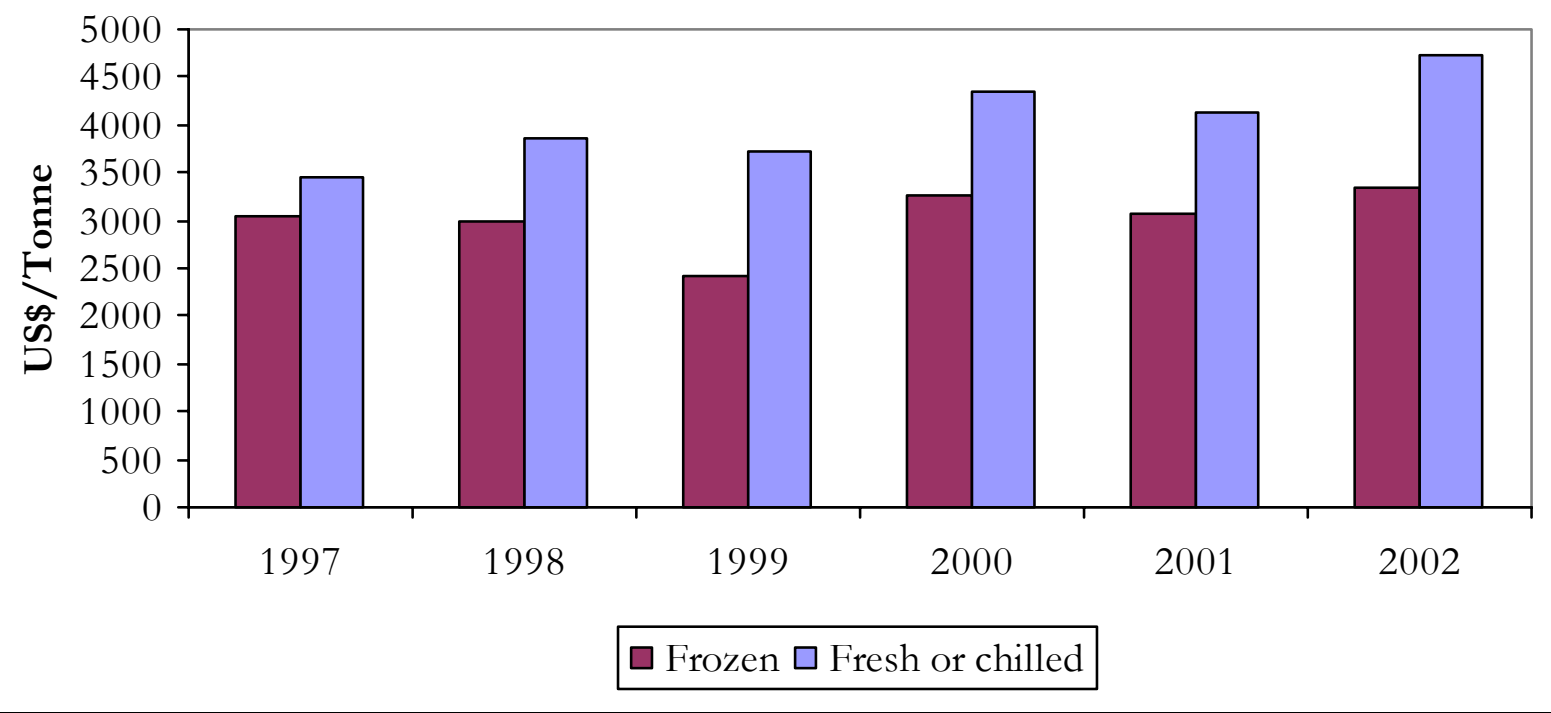

Source: CBS (2002).

Despite the restrictions on exports to the EU, Nile perch continued to dominate fish and fishery product exports from Kenya. Thus, in 2000 for example, frozen Nile perch fillets accounted for 88 percent of total fish and fishery products exports by value and 92 percent by volume. Other significant exports include fresh, chilled and boiled crustaceans, frozen marine fish, frozen cephalopods and unsalted dried fish, although the value of each of these was less than US\$1 million.

The EU had been an important and high-value market for fresh Nile perch fillets. As a result of the restrictions, however, the unit price of fresh fillets declined in both EU and non-EU markets as Kenyan (and Tanzanian and Ugandan) exporters, in particular those that lacked the capacity to 
produce frozen fillets, competed more intensely within a diminished market (Figure 20). This reflected not only the closure of EU markets as a direct result of the restrictions, but also the diminished reputation of fresh Nile perch amongst many buyers world-wide because of the EU's actions.

Table 9. Exports of fresh, chilled and frozen fish fillets by destination, 1997-2002 (Tonnes):

\begin{tabular}{|c|c|c|c|c|c|c|}
\hline Country & $\mathbf{1 9 9 7}$ & $\mathbf{1 9 9 8}$ & $\mathbf{1 9 9 9}$ & $\mathbf{2 0 0 0}$ & $\mathbf{2 0 0 1}$ & $\mathbf{2 0 0 2}$ \\
\hline Israel & 4244 & 5252 & 4550 & 7160 & 3984 & 2887 \\
\hline Netherlands & 3033 & 856 & 3208 & 26 & 4126 & 4458 \\
\hline Singapore & 1669 & 745 & 532 & 910 & 346 & 323 \\
\hline Germany & 1550 & 175 & 298 & 0 & 1449 & 1383 \\
\hline Greece & 789 & 1002 & 183 & 0 & 103 & 118 \\
\hline Japan & 387 & 1221 & 1951 & 2183 & 1234 & 1669 \\
\hline Malaysia & 318 & 36 & 87 & 360 & 399 & 299 \\
\hline France & 309 & 19 & 0 & 0 & 0 & 0 \\
\hline USA & 288 & 134 & 167 & 415 & 1491 & 1244 \\
\hline Portugal & 244 & 25 & 124 & 0 & 166 & 202 \\
\hline United Arab Emirates & 222 & 352 & 233 & 449 & 440 & 208 \\
\hline Belgium & 208 & 27 & 7 & 1 & 822 & 788 \\
\hline Hong Kong & 175 & 173 & 235 & 1226 & 211 & 374 \\
\hline Australia & 174 & 772 & 1829 & 1439 & 2083 & 1323 \\
\hline Italy & 1 & 0 & 0 & 0 & 402 & 721 \\
\hline Other & 452 & 200 & 547 & 1359 & 649 & 489 \\
\hline Total & $\mathbf{1 4 0 6 4}$ & $\mathbf{1 0 9 8 9}$ & $\mathbf{1 3 9 4 9}$ & $\mathbf{1 5 5 2 8}$ & $\mathbf{1 7 9 0 6}$ & $\mathbf{1 6 4 8 2}$ \\
\hline
\end{tabular}

Source: CBS (2002).

The unit price of frozen fish fillets in non-EU markets remained stable through the period 199698 , reflecting the greater number and variety of markets available to exporters and their ability to divert supplies between these according to market conditions (Figure 21). However, the price of frozen fillets did decline in the EU such that the differential between EU and non-EU market prices was almost eradicated by the end of 1998. Through 1999 and 2000, however, EU prices recovered and in 2001 there was a premium of over 15 percent over frozen fillet exports to nonEU markets.

\subsection{Landed volume and price of Nile perch}

The restrictions on exports to the EU were imposed at a time when the landed catch of Nile perch was already in decline. For example, over the period 1994-96 the landed volume dropped from 103,995 tonnes to 96,471 tonnes (Figure 22). However, the loss of access to EU markets immediately resulted in a reduction in demand for raw fish as industrial processing facilities ceased operating or reduced output. The local market was unable immediately to absorb the surplus, for example because the artisanal processing sector is now insignificant on many landing beaches, and the catch declined significantly in 1997 as fishers reduced their fishing effort and/or diverted attention to other fish, in particular tilapia. 
Figure 20. Unit value of fresh and chilled fish fillets by destination, 1996-2001:

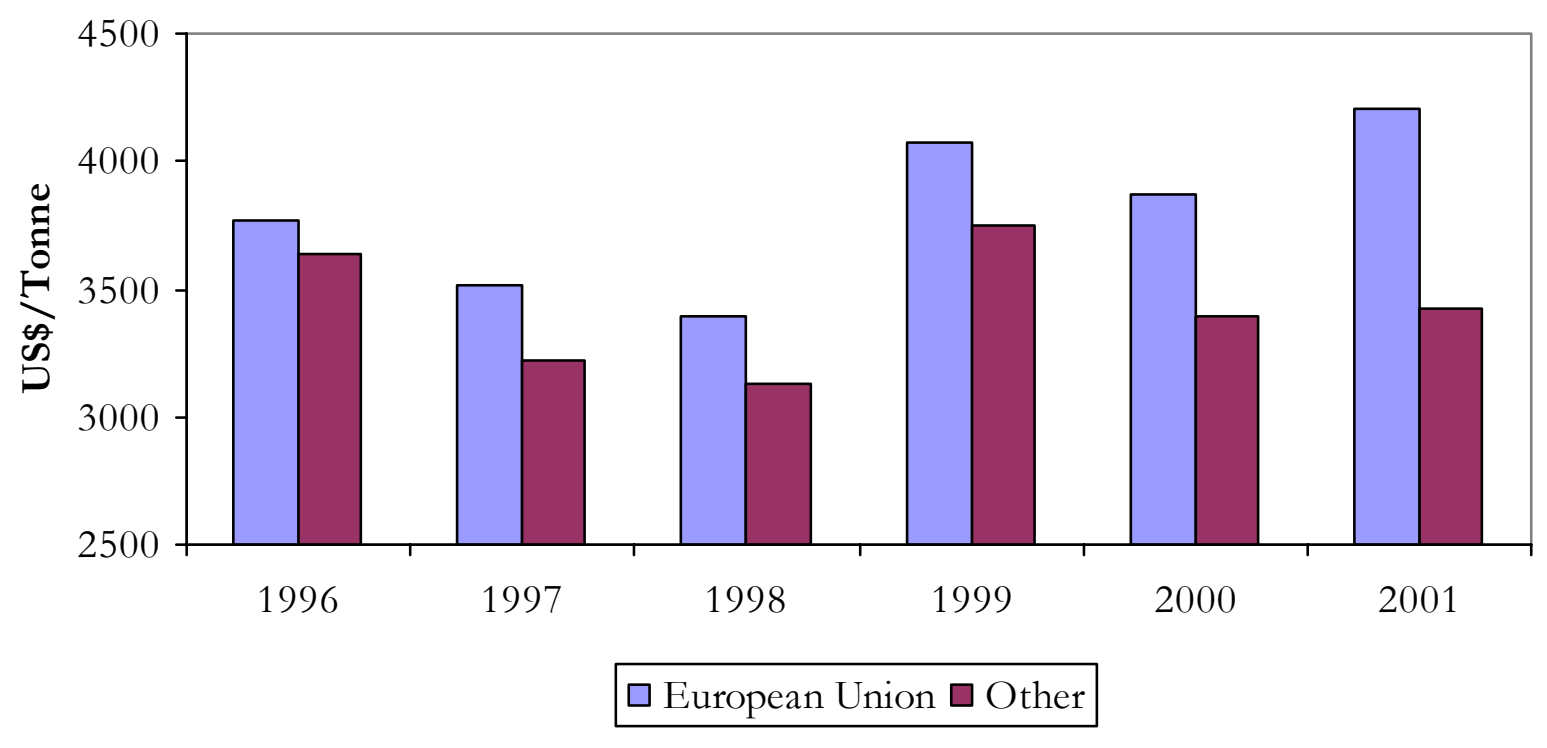

Source: CBS (2002).

Figure 21. Unit price of frozen fish fillets by destination, 1996-2002:

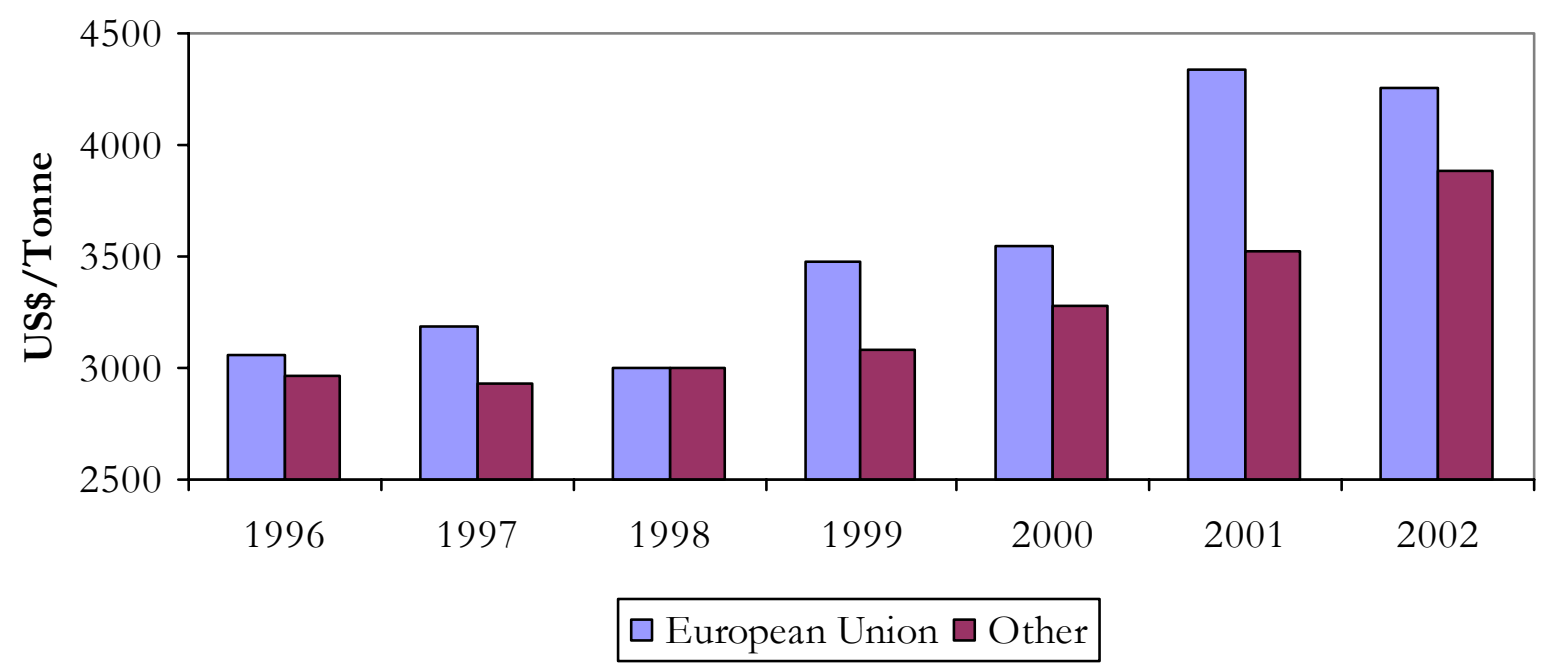

Source: $C B S(2002)$.

In 1998, the catch began to recover and by 1999 was greater than the period immediately prior to the restrictions, as demand from the industrial processing sector recovered with exporters exploiting alternative markets. Further, the landings of other fish continued to increase ${ }^{43}$. For example, the volume of Tilapia niloticus increased from 10,765 tonnes in 1996 to 23,226 tonnes in 2000. Many fishers had no alternative source of cash income and had little alternative but to continue fishing despite any changes in local market conditions. However, once the ban was lifted and exports to the EU commenced, landings of other fishes declined. For example,

43 These four fish accounted for 97 percent of landings in 2001. 
landings of Tilapia niloticus fell to 16,251 tonnes in 2002, whilst landings of other tilapia became negligible ${ }^{44}$.

Figure 22. Total landings of fish in Kenyan waters of Lake Victoria by species, 1996-2002:

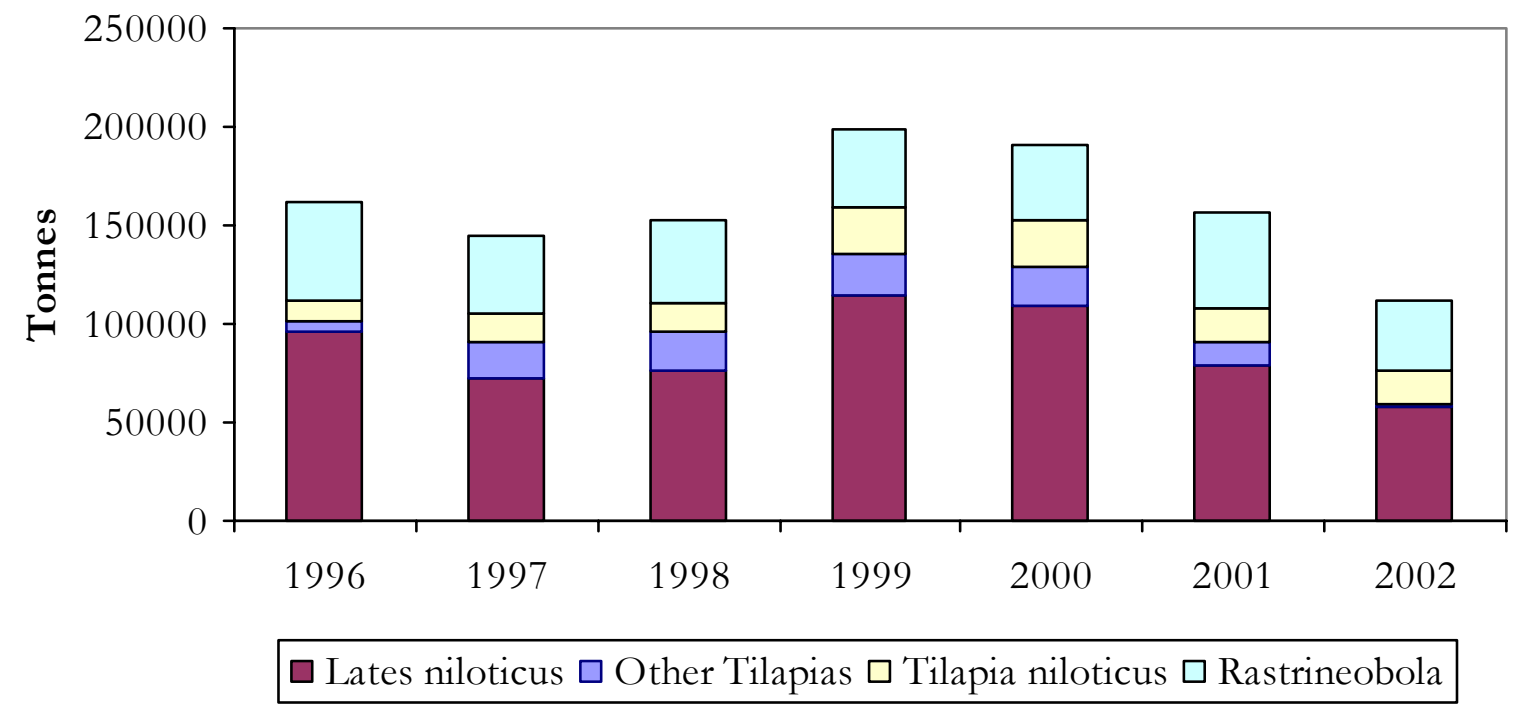

Source: Fisheries Department

Whilst the onset of restrictions on exports to the EU resulted in an immediate decline in the landed price of Nile perch, this was soon at least partially offset by a decline in fishing effort applied to Nile perch and demand from local markets (Abila and Jansen, 1997; Bokea and Ikaiara, 2000). Further, expanded markets soon became established in urban centres, particularly Nairobi, Mombasa and Nakuru. For example, Nile perch became regularly available at the City Market in Nairobi whereas previously it had been rarely offered for sale. Thus, the real price of Nile perch declined from KSh45.5 per kilogram in 1996 to KSh27.4 per kilogram in 1997, but recovered to KSh36.9 per Kilogram in 1998 (Figure 23). However, it was not until 2001 that the landed price fully recovered in real terms, despite a significant increase in the nominal price throughout the period 1997 to 2001. Subsequently, through 2002 the landed price of Nile perch increased significantly in both nominal and real terms, reflecting the decline in the volume of catch and competition between industrial fish processing operating well below capacity.

Whilst the landed price of Nile perch declined directly restrictions were imposed on exports to the EU, the price of other fish increased or remained constant (Figure 24). In particular, the landed price of Tilapia niltoticus increased significantly through 1997 and 1998, and in both years actually exceeded the price of Nile perch. This is in stark contrast to the previous twenty years, during which time the price of tilapia was both lower than and declined relative to the price of Nile perch. Thus, one of the responses by fishers to the diminished market demand and price for Nile perch was to increase the effort devoted to other fish species and landed volumes increased significantly, although subsequently declined through 2002 .

\footnotetext{
${ }^{44}$ These variations in the level and composition of catch cannot be entirely attributed to the restrictions on exports to the EU. Local environmental conditions (in particular the spread of water hyacinth) and the impact of the intensity of fishing on the fish population have also had a major effect.
} 
The impact of the EU's measures on local fishing communities around Lake Victoria will reflect the great dependency that these communities now have on the industrial fish processing sector which, in turn, is highly export-oriented (Ong'ang'a, 2002). In view of the decline in artisanal processing at landing beaches and the inability of local markets to absorb significant additional volumes of Nile perch, any decline in demand is generally absorbed through reductions in the landed price of fish. In turn, because of the limited alternative sources of cash incomes available to fishers this generally translates into a decline in earnings within the local fishing communities (Mkisi, 1991; Jansen, 1997).

Figure 23. Mean annual landed price of Nile Perch in Kenyan areas of Lake Victoria, 19962002:

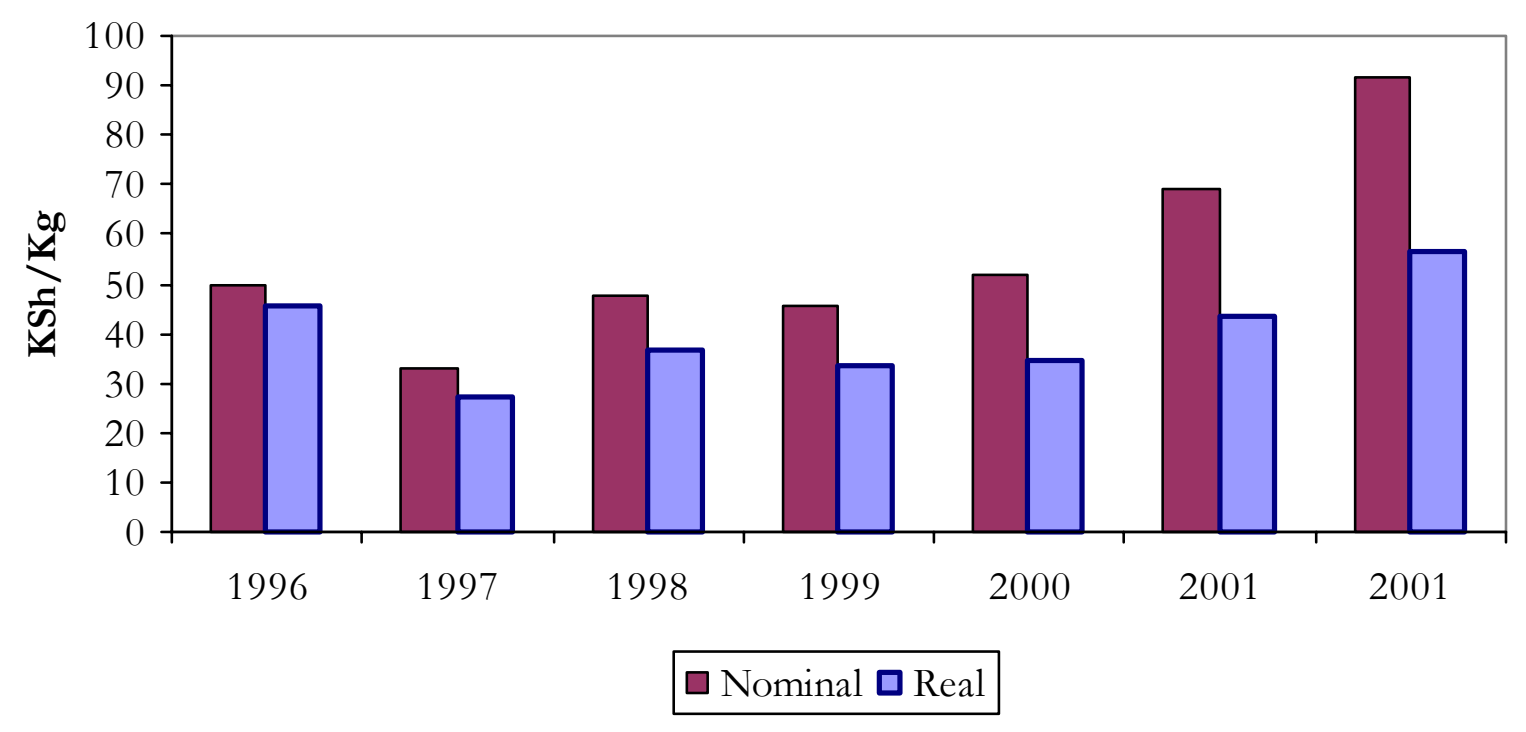

Note: Real prices deflated using IMF consumer price index (1995=100).

Source: Fisheries Department.

No data are available on the income of fishers and how this changed over the period 1996-2001. Thus it is not possible to assess whether and the degree to which livelihoods within the communities around Lake Victoria were adversely affected. However, the significant and prolonged decline in the real price of Nile perch combined with reductions in the total landed catch would suggest that the cash incomes of fishers diminished. Indeed, the aggregate real landed value of fish declined from US\$103.3 million in 1996 to US\$63.0 million in 1997 (Figure 25). Following the removal of restrictions on exports to the EU, although the landed price of Nile perch increased, this was offset by a decline in landed volumes of all fish, such that the aggregate value of fish landed through 2001 and 2002 remained below the level of 1996. 
Figure 24. Mean annual landed price of fish in Kenyan waters of Lake Victoria by species, 1996-2002:

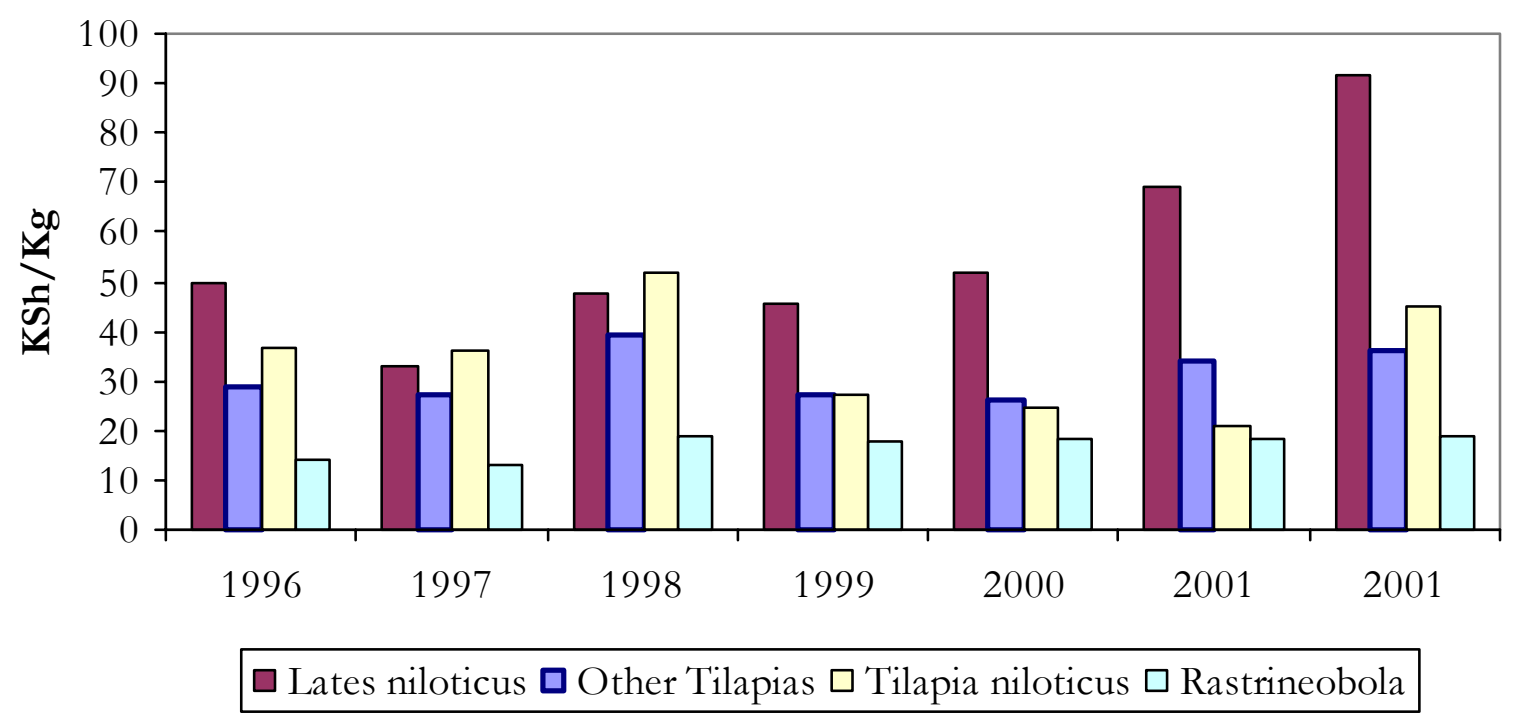

Source: Fisheries Department

Figure 25. Total landed value of fish in Kenyan waters of Lake Victoria, 1996-2002:

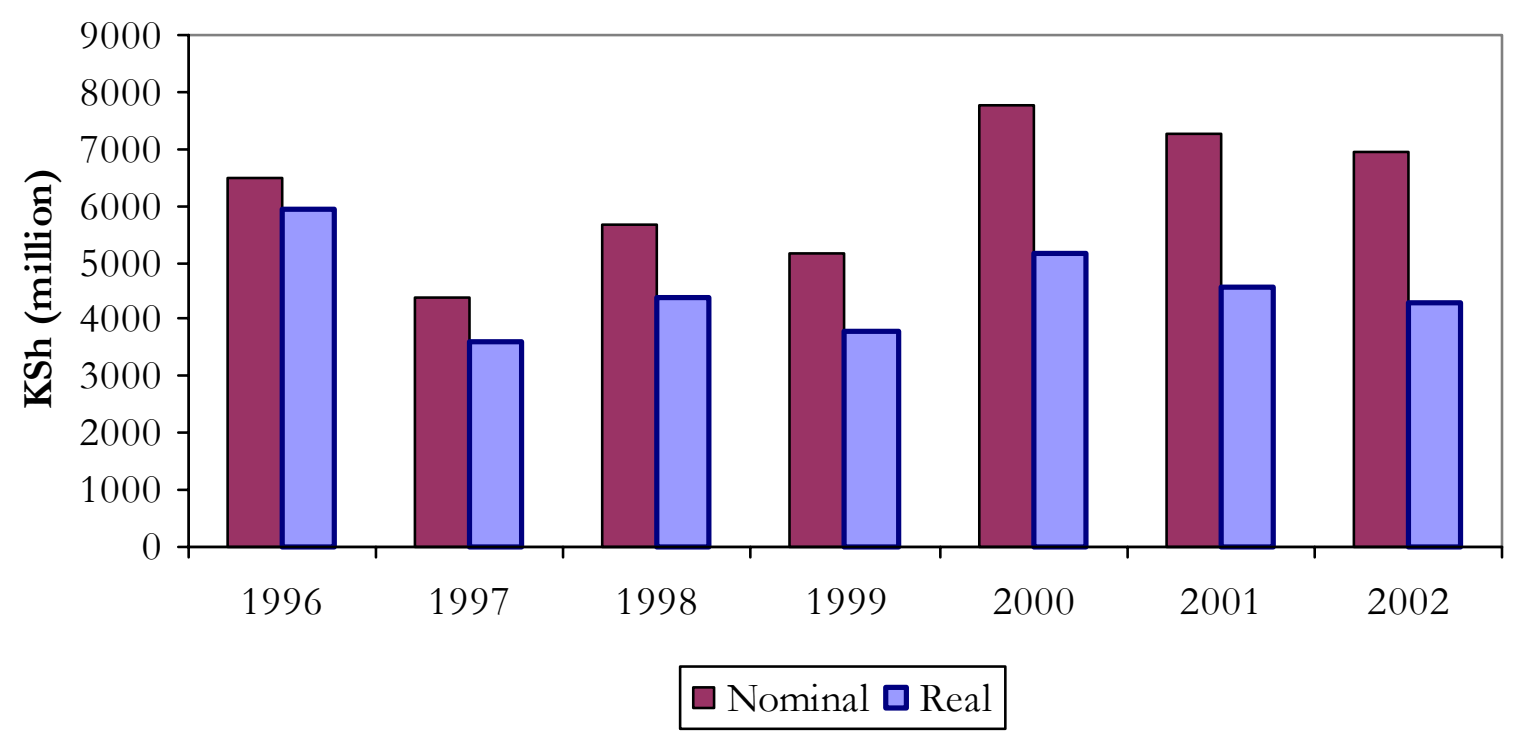

Note: Real prices deflated using IMF consumer price index $(1995=100)$.

Source: Own calculations

Arguably, much of the impact of restrictions on exports of Nile perch to the EU were passed down the supply chain to fishers through lower landed prices. Indeed, SMEC (2002) suggest that the returns to fishing are highly sensitive to fluctuations in the landed price; most of the costs borne by boat owners are fixed and independents of either the size or the value of the catch. Further, around 80 percent of the value of the landed catch is paid to boat crews suggesting that 
any changes in landed prices will be reflected in the incomes of local fishers as well a boat owners. Indeed, there is evidence of the retrenchment of investments in fishing vessels. Thus, since the restrictions on exports to the EU was lifted, the number of registered craft declined from 13,800 in 2000 to 12,209 in 2002 (Fisheries Department, 2003).

The impact of the EU's measures on fish traders is likely to have been limited. Whilst traded volumes of Nile perch may have initially declined, it has been shown that the income of traders is insensitive to the landed price of Nile perch (Visser, 2002; SMEC, 2002).

Table 10. Loss of sales during periods of restrictions on exports to EU:

\begin{tabular}{|c|c|c|c|}
\hline \multirow[t]{2}{*}{ Factory } & \multicolumn{3}{|c|}{$\begin{array}{c}\text { Loss (US\$) } \\
(\% \text { loss in parentheses) }\end{array}$} \\
\hline & 1997 & 1998 & $1999-2000$ \\
\hline A & $\begin{array}{c}0 \\
(0.0 \%)\end{array}$ & $\begin{array}{c}0 \\
(0.0 \%)\end{array}$ & $\begin{array}{c}0 \\
(0.0 \%)\end{array}$ \\
\hline B & $\begin{array}{c}900,000 \\
(30 \%)\end{array}$ & $\begin{array}{c}640,000 \\
(18 \%)\end{array}$ & $\begin{array}{c}510,000 \\
(12 \%)\end{array}$ \\
\hline $\mathrm{C}$ & $\begin{array}{c}260,000 \\
(30 \%)\end{array}$ & $\begin{array}{c}260,000 \\
(10 \%)\end{array}$ & $\begin{array}{c}390,000 \\
(40 \%)\end{array}$ \\
\hline $\mathrm{D}$ & $\begin{array}{c}640,000 \\
(50 \%)\end{array}$ & $\begin{array}{c}960,000 \\
(40 \%)\end{array}$ & $\begin{array}{l}140,000 \\
(70 \%)\end{array}$ \\
\hline $\mathrm{E}$ & - & - & - \\
\hline F & $\begin{array}{c}0 \\
(0.0 \%)\end{array}$ & $\begin{array}{c}510,000 \\
(40 \%)\end{array}$ & $\begin{array}{c}380,000 \\
(20 \%)\end{array}$ \\
\hline G & $\begin{array}{l}640,000 \\
(100 \%)\end{array}$ & $\begin{array}{l}770,000 \\
(100 \%)\end{array}$ & $\begin{array}{c}380,000 \\
(30 \%)\end{array}$ \\
\hline $\mathrm{H}$ & - & - & - \\
\hline $\mathrm{N}$ & $\begin{array}{c}260,000 \\
(50 \%)\end{array}$ & $\begin{array}{c}192,000 \\
(30 \%)\end{array}$ & $\begin{array}{c}260,000 \\
(50 \%)\end{array}$ \\
\hline $\mathrm{M}$ & $\begin{array}{l}510,000 \\
(100 \%)\end{array}$ & $\mathrm{n} / \mathrm{a}$ & $\mathrm{n} / \mathrm{a}$ \\
\hline $\mathrm{O}$ & - & - & $\mathrm{n} / \mathrm{a}$ \\
\hline $\mathrm{P}$ & $\begin{array}{c}510,000 \\
(80 \%)\end{array}$ & $\begin{array}{c}640,000 \\
(80 \%)\end{array}$ & $\begin{array}{c}890,000 \\
(80 \%)\end{array}$ \\
\hline $\mathrm{Q}$ & $\begin{array}{l}- \\
-\end{array}$ & - & $\mathrm{n} / \mathrm{a}$ \\
\hline $\mathrm{R}$ & $\begin{array}{c}510,000 \\
(80 \%)\end{array}$ & $\begin{array}{c}770,000 \\
(90 \%)\end{array}$ & $\begin{array}{l}900,000 \\
(100 \%)\end{array}$ \\
\hline
\end{tabular}

Source: Survey of fish processors, March 2003. 


\subsection{Industrial fish processing facilities}

The impact of the loss of EU markets on individual fish processing facilities will have reflected a number of factors. Firstly, the degree of dependency on exports to the EU and, more specifically, fresh fish fillets. Plants that did not have the installed capacity to manufacture frozen fillets will have experienced an almost total loss of their markets with little option to divert to alternative export destinations. Secondly, the degrees to which reductions in export prices were offset by lower prices for raw Nile perch at landing beaches. SMEC (2002) suggest that fish processors typically operate on relatively low operating margins and their returns are highly sensitive to changes in the landed price of fish. Thirdly, the ability of processors to identify and exploit alternative export markets; exporters with experience in other markets (even at some time in the past) and/or well-established connections were more likely to have been able to offset the loss of EU markets through sales to other countries.

Thus, the loss of sales during the three periods of restrictions on exports to the EU varies widely (Table 10). In some cases exporters reported experiencing no loss; these were generally minor exporters to the EU, had a broad export base and/or did not manufacture fresh Nile perch fillets. In others, very significant losses, often exceeding 50 percent of sales, were reported. Further, some plants had experienced a total, or near total, loss of sales. Most of these subsequently ceased operations.

Care must be taken, however, in interpreting these data, which are self-reported losses based on face-to-face interviews and, perhaps, provide an over-estimate of the real impact on any particular exporter ${ }^{45}$. Indeed, there appears to be a considerable inconsistency between the trends in total exports by value over the period 1996 to 2001 and the losses reported by the fish processors. For example, it seems that these estimates ignore any trade diversion effects whereby losses of EU markets were offset by increased exports to other countries.

\section{COMPLIANCE STRATEGIES AND COSTS}

\subsection{Legislation and public sector controls}

Previous to the ban on exports to the EU, the Kenyan fish sector as a whole had made little progress in restructuring hygiene and other food safety controls. For example, landing beaches had received virtually no attention and in many cases lacked even the most basic of infrastructure. Inspection and other government controls were ineffective and constrained by lack of resources. Many industrial food processing facilities had not implemented HACCP and otherwise did not comply with generally accepted good manufacturing practice. Further, there was very little co-ordination or cooperation between government and the private sector, different levels of the supply chain, and between the individual industrial fish processors. However, the need to address the concerns of the EU as a means to regain market access brought about wholesale and fundamental change to the sector in a relatively short period of time. More still needs to be done, particularly at the major landing beaches. However, arguably, the Nile perch fishery and export supply chain is better able to meet the needs of the global market place today than it has ever been.

\footnotetext{
${ }^{45}$ Compared, for example to data on annual total export values.
} 
Many of the changes that have taken place throughout the supply chain are described below within the context of general efforts to achieve compliance with EU requirements relating to hygiene and controls of pesticide residues in fish and fishery products. However, notable changes that have been brought about as a direct result of the ban on exports include the formation of the Association of Fish Processors and Exporters of Kenya (AFIPEK) and the reorganization of administrative responsibilities within government for the regulation of the fish sector. AFIPEK is the first real attempt by the industrial fish processors to cooperate with one another and present a united front to the Government of Kenya and international and intergovernmental agencies, for example the European Commission and providers of technical assistance such as FAO and UNIDO. The rationalization of administrative responsibilities such that the Fisheries Department now has sole responsibility for regulation of the fish sector, including the inspection and approval of processing establishments for export to the EU, facilitates more effective development and implementation of controls and effective and timely response to emerging issues. Each of these is discussed in more detail below.

Although the Government of Kenya had established a Task Force to address quality controls in the fish and fishery products sector in 1994, very little progress was made in the period to the end of 1997. Indeed, it is evident that much of the effort to enhance capacity was a direct result of the restrictions on exports to the EU. However, in the period 1998-2002 (and particularly 2001-2002), very major advances were made, such that the controls in place today are largely equivalent to EU requirements.

In 1994 it had been decided that the Competent Authority for the purpose of approving processing establishment and factory vessels for export to the EU would be the Public Health Department of the Ministry of Health (Fisheries Department, 2001). This was largely based on the existing responsibility of the Public Health Department to certify goods for export under the Public Health Act. In the case of fish and fishery products, however, multiple agencies had responsibility for inspecting and approving fish processing facilities, namely: Public Health Department, Ministry of Health; Fisheries Department, Ministry of Agriculture and Rural Development; and KEBS (Fisheries Department, 1998). Both Public Health Officers of the Public Health Department and Local Fisheries Inspectors within the Fish Inspection and Quality Control Unit of the Fisheries Department made weekly random visits to processing establishments. Both had the power to withdraw licenses to process. Further, establishments were audited twice annually by Senior Fisheries Inspectors, whilst KEBS audited annually against the KEBS standard.

The system implemented for the issuing of Export Health Certificates also involved multiple agencies. Each consignment for export required a Health Certificate issued by a Public Health Officer and a Fish Export Certificate issued by the Fisheries Department. The later was only issued when the Fisheries Department was in receipt of a fish inspectors report. Once both certificates had been obtained, the Public Health Department would issue an Export Health Certificate and the consignment could be exported.

Initially, attempts were made to implement coherent and consistent procedures for the approval of fish processing establishments for export to the EU by establishing a task force consisting of officials from the Public Health Department, Fisheries Department and KEBS. This task force 
was charged with approving establishments on the basis of inspection reports and otherwise to co-ordinate the activities and responsibilities of the three departments/agencies.

In 1998, European Commission inspectors identified a number of fish processing establishments that had been approved for export to the EU but that failed to comply with EU requirements. Subsequently, the Task Force reviewed all establishments in Kenya. Only one establishment was fully approved for export to the EU, although a further three were given conditional approval whilst non-conformities were being addressed. Five establishments were disapproved and a further four, which had not been exporting to the EU, were prevented from exporting to any country because they did not meet EU requirements (Ministry of Health, 1998a). Further, enhanced and more secure procedures were put in place for issuing Export Health Certificates in the light of two cases of fish processors exporting fish without a permit. These included the nullification of certificates that were missing, introduction of a lockable official seal on Certificates, and security printing of Fish Export Permits.

Over time it became apparent that the involvement of three separate ministries/agencies and in particular communication/co-ordination difficulties and the potential for over-lap of responsibilities was a significant impediment to conformity with EU requirements. Further, the EU itself raised concerns about the manner in which the system operated and its ability to prevent the export of consignments of fish and fishery products that did not meet regulatory requirements (European Commission, 1998). Thus, it eventually was recognized that a single authority was required to regulate the fish and fishery products sector and implement the controls required for export to the EU (Fisheries Department, 2001a).

In August 2002, the Fisheries Department was made the Competent Authority and given sole responsibility for food safety controls relating to fish and fishery products and the approval of processing establishments (Annex II). Further the functions of the Competent Authority were clearly defined, namely:

- Monitor fishing grounds for pollutants.

- Control fish landing, handling and transportation.

- Work with KEBS in establishment of Kenya standards for fish handling and processing.

- Approve the establishment and operation of fish processing plants and vessels.

- Carry out inspection of fish processing establishments to ascertain compliance with Kenyan standards and other international standards for fish handling and processing.

- Lay down procedures to be followed for compliance with the Fisheries (Fisheries Quality Assurance) Regulations.

- Approve the establishment of new fish auctions and wholesale markets and carry out inspections.

- Maintain registry of fish processing establishments and vessels, auction and wholesale markets and landings sites approved under Fisheries Act.

A Standing Committee of the Ministry of Agriculture and Rural Development was charged with the management of the Competent Authority (Fisheries Department, 2001a). This is headed by Permanent Secretary, and the membership includes the Director of Fisheries and Director of Veterinary Services. This committee is responsible for approving landing sites and processing 
establishments for export, appointing fisheries inspectors and approving national analytic laboratories for fish quality and safety.

The Fish Quality Control and Inspection unit within the Fisheries Department is responsible for the day-to-day operation of the Competent Authority, including:

- Co-ordination of fish inspection, quality control and assurance.

- Formulation and up-dating of generic HACCP plans, GMP, SSOP.

- Approval of HACCP and SSOP documents of processing establishments.

- Training of inspectors.

- Auditing and verification of field reports.

- Formulation and updating of legislation and standards for fish and fishery products.

- Formulation and updating of inspection procedures and documentation.

The centralisation of food safety controls within the Fisheries Department has swept away the prevailing bureaucracy and streamlined procedures and functions. Indeed, it is perhaps no coincidence that the ban on exports to the EU was lifted only three months after the Fisheries Department was made the Competent Authority. Indeed, one processor remarked to the authors that more was achieved in the three months following August 2002 than in the three years previously!

These reforms have also streamlined the procedures for issuing Export Health certificates. A Fish Export Permit is completed by fish inspectors for approval by the Director of Fisheries. An Export Health Certificate is then issued when this Permit is presented at designated offices of the Fisheries Department.

In 2001, the Fisheries Department established a Plan of Action for improving the control of fish and fishery products (Fisheries Department, 2001a; 2001b). The key elements included:

- Countrywide inspection to classify establishments.

- Review of fish processing establishments approved to export fish and fishery products to the EU by the Competent Authority's Standing Committee. Approved establishments to be provided with Permanent Reference Number.

- Completion of first phase of landing beach improvements.

- Training of fish inspectors to familiarize with the new regulations.

- Training of more fish inspectors trainers.

- Sensitization of fishers and fish handlers.

- Formation and operation of Landing Beach Development Committees.

- Formation and operation of Competent Authority systems audit.

Perhaps indicating the Commitment of the Fisheries Department to ensure the effective control of fish and fishery product exports to the EU, the first consignments were not approved until 29 January 2001, two months after the lifting of restrictions. This ensured that the facilities that were approved to export were fully in compliance with EU requirements.

Efforts to enhance food safety capacity with respect to fish and fishery products and achieve compliance with EU requirements came partly within the objectives of the Lake Victoria Environmental Management Program (LVEMP). This is described in Box 2. 


\section{Box 2. Lake Victoria Environmental Management Program (LVEMP):}

The (LVEMP) covered Kenya, Tanzania and Uganda, with funding from national governments, Global Environment Facility (GEF) and the World Bank. The total project cost was US\$77.6 million, of which US\$26.9 million was for activities in Kenya (World Bank, 1996). In the case of Kenya project activities came to an end in December 2002.

An aim of the LVEMP was "to maximise the sustainable benefits to riparian communities from using the resources within the basin to generate food, employment and income, supply safe water, and sustain a disease-free environment". The project consisted of a series of activities, one of which addressed the strengthening of extension, monitoring and enforcement capabilities of national fisheries administrations, with a budget of US\$14.1 million (World Bank, 1996). Specific elements included:

- Harmonisation of laws between countries.

- Training and empowerment of fisheries law enforcement officers.

- Establishment of customs posts at selected border landings sites.

- Promoting organizations of fisher-folk to, amongst other things, monitor fisheries of the Lake.

- Establish one fish quality laboratory in each country to carry out tests on microbes, heavy metals, pathogens, pesticides and other contaminants.

- Study ways to reduce post-harvest losses of fish through improvements in handling and processing and harmonising data collection

- Small investments in community water supply from ground-water, sanitary facilities, local roads and health facilities.

This required investment in the construction of community facilities, technical assistance, workshops, training, laboratory and field equipment, vehicles and boats, sanitation, roads and health etc.

In 1997, there was no specific legislation covering hygiene and other food safety controls for fish and fishery products. Rather, controls were implemented under general food safety legislation and the Fisheries Act. A Code of Hygiene Practice for the handling, processing and distribution of fish had been established by KEBS in 1986, although this was out-dated. However, over the period 1998 to 2000 the regulatory framework was up-dated in line with EU requirements. First, a revised Kenya Standard Code of Practice for Handling, Processing and Distribution of Fish was issued in 1998. Second, the Fisheries (Fisheries Quality Assurance) Regulations were promulgated in August 2000, laying down specific hygiene requirements for fish and fishery products. Both were largely based on EU Directive 91/493/EEC.

The government of Kenya has implemented a system of user fees to provide resources to support these controls. Fish processing plants require a Certificate of Compliance in order to operate. This is issued annually following inspection by the Fisheries Department. A fee of KSh35,000 fee is payable. Further, exporters require a Fish and Fish processing Export Health Certificate for each consignment, for which a fee of KSh1,000 is charged (Visser, 2003).

Whilst the Fisheries Act only permits fish from Kenyan waters to be landed at Kenyan beaches, this had not been widely enforced. Recently, however, the Fisheries Department has established five points for monitoring the entry and exit of fish and fishery products from neighbouring 
countries (Fisheries Department, 2001a; 2001b). Further, efforts are underway to harmonise regulations and procedures with Tanzania and Uganda, recognizing the inevitable potential for cross-border movement and landing of fish.

The Fisheries Department has implemented a program of training for fish inspectors and industry quality managers, including refresher courses on HACCP and quality control (Ministry of Health, 1998; Gitonga et al., 2000). For example, in December 199921 fish inspectors attended an intensive refresher course on HACCP at Moi University. Subsequently, in June 2000 a seminar was organized on fish quality assurance aimed at up-dating industry quality control managers and official fish inspectors. Further training is planned to train trainers in fish quality control (Fisheries Department, 2001b). Officers from the Fisheries Department have also attended various regional seminars/workshops organized by FAO and other agencies.

A consultant funded by the European Commission to assess priorities for capacity-building in Kenya provides estimates of the costs of food hygiene training for fish inspectors and trainers, including a tour of processing facilities in the EU to enhance awareness and experience (Landell Mills, 2001). The total cost is around US\$71,300, which would provide training for five inspectors of fish processing facilities and 15 other trainers.

The Fisheries Department has also made efforts to inform and train fishers. Through the Lake Victoria Environmental Management Programme (LVEMP) public seminars on responsible fisheries and participatory fisheries management have been organized. Further, the qualitycontrol sub-component of the LVEMP sponsored three workshops in which 180 fishers were sensitized on improved fish handling methods.

A major constraint in the implementation of effective controls on hygiene in fish processing and pesticide residues in fish was laboratory testing capacity. Indeed, the report of the European Commission inspectors in 1998 commented that there was no evidence that the three laboratories that were visited were actually operational (European Commission, 1998). In certain cases there was a lack of basic laboratory infrastructure and/or laboratories did not have the equipment to undertake the full range of tests required. In others, the methods employed were outdated and did not provide the required level of precision and/or the laboratory had not implemented a coherent system of Good Laboratory Practice (GLP), had not been accredited by an outside agency and did not participate in an appropriate proficiency scheme (see for example European Commission, 1998; 1999).

In the case of pesticide residue testing, for example, the laboratories of both the Government Chemist and KEBS were considered inadequate to undertake the required tests. The laboratory of the Government Chemist was in poor repair, equipment was outdated, certain of the required chemicals were unavailable and the methods employed were inappropriate (European Commission, 1999). However, the laboratory operated by KEPHIS was considered to be generally satisfactory in terms of GLP, equipment, methods of analysis etc., although there was some need for improvements to operating procedures and record-keeping.

Subsequently, significant investment has been made in laboratory capacity in Kenya. The laboratory of KEBS has been accredited internationally to ISO17025 and the staff and equipment 
are sufficient to undertake pesticide residue analysis in fish, water and sediment. Procedures at the KEPIS laboratory has also been improved in the light of the inspection report from the European Commission

The Fisheries Department is currently implementing a plan to up-grade its laboratories in Nairobi and Mombasa, at a total cost per laboratory of US\$2,900 for chemical analytical equipment and US\$2,500 for microbiological analytical equipment (Gitonga et al., 2000). A new laboratory for chemical analysis was constructed in Kisumu as part of the LVEMP. However, there are plans to equip this for microbiological analysis at a cost of US\$2,500. The up-grading of the Nairobi laboratory for microbiological analysis was completed in June 2003 at a cost of US\$2,500. However, the development of capacity to undertake chemical analysis has yet to be implemented and the Fisheries Department is currently utilising KEPHIS for this purpose. Thus, the total cost of laboratory up-grading and renovations will be around US\$11,100. Estimates of the recurring costs of operating these up-graded laboratory facilities, for example reagents, electricity, general maintenance and additional labour are not available.

Whilst Kenya appears to be near to full compliance with EU requirements, it is interesting to note that this has taken considerably longer to achieve than in Uganda and (particularly) Tanzania. Further, both of these countries managed to have restrictions lifted on exports of Nile perch ahead of Kenya. A key factor was the fragmented administrative structure that prevailed in Kenya to August 2000. Since all of the responsibilities and activities of the Competent Authority were brought together within the Fisheries Department significant progress has been made. Further, a more strategic vision seems to have been adopted that looks to the development and sustainability of capacity into the future.

\subsection{Industrial fish processing sector}

By the mid-1990s a total of 15 industrial fish processing facilities had been established in Kenya that handled almost exclusively Nile perch. Whilst some of these facilities were purpose-built, many were converted from premises built for another purpose, including the manufacturing of non-food products. Thus, the suitability of the factory and general level of repair varied significantly. Further, although most plants claimed to be aware of regulations in the EU and had complied with them (LVFRP, 1999a), there were significant differences in the extent to which they had actually implemented the required standards of hygiene and quality management systems. Thus, when the European Commission undertook inspection visits in 1997 and 1998 it found numerous facilities that did not comply with its requirements (European Commission, 1998).

Over the period 1998-2002 significant efforts were made to enhance hygiene standards within the industrial fish processing sector in order to comply with EU requirements, which had since been embodied in Kenya legislation. Indeed, when the European Commission again undertook inspections in March 2002, it found that facilities met the requirements of EU legislation concerning structure, maintenance and hygiene, with the exception of a few issues that could be corrected relatively easily (European Commission, 2003). Boxes 3 to 5 provide examples of the improvements that processors have made in order to comply. 
Although it is estimated that around 82 percent of installed capacity in the fish processing sector complies with EU requirements as assessed by the Kenyan Competent Authority, a number of fish processing facilities were unable to up-grade their facilities and subsequently stopped operating. Currently, six processing facilities are idle (Figure 26).

It is evident that non-recurring costs of compliance borne by individual companies varied significantly, reflecting the varying standards of hygiene that prevailed within the sector in 1998 (Table 11). Thus, for example Plant G had made an investment of US\$128,000, whilst Plants E and $\mathrm{H}$ had only minimal costs. In general, costs were generally greatest where factories had undergone major structural change in order to improve the general fabric of the facility, achieve segregation of operations and/or implement effectual pest control. These facilities generally had lower existing standards of hygiene and had not previously made the necessary investment to upgrade hygiene standards. Further, they were generally housed in older buildings, often converted from some alternative previous use, and/or had severe space constraints.

The total cost of compliance for the fish processing sector is estimated at US\$557,000. This implies an average cost per plant of US $\$ 39,785$. Whilst this is not a large amount given current exports valued at US\$33.52 million, given that six plants are not operational, a significant proportion of the sector has clearly derived no pay-off from this investment at all. Further, there is no clear relationship between size of fish processing operation and non-recurring costs of compliance; some of the smaller processors incurred costs of the same order of magnitude as the larger processors.

Figure 26. Capacity and operating volumes of operational fish processing facilities, 2002:

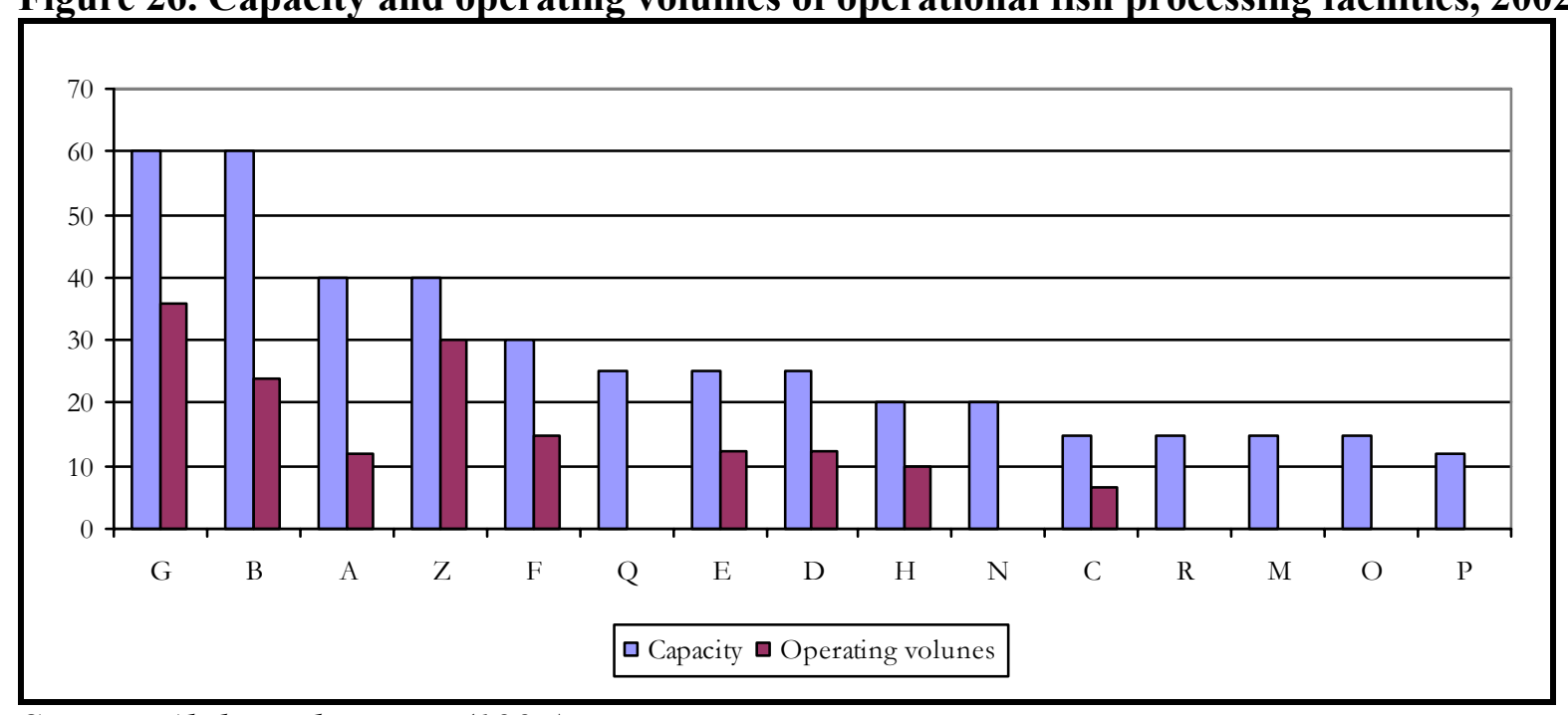

Source: Abila and Jansen (1997).

A number of plants that are not currently operational had made some investment in the up-grade of their facilities, in some cases significantly so (for example Plants I and J). Ironically, a number of these were prevented from completing the necessary investment because of the loss of EU markets; many were almost entirely dependent on exports of fresh Nile perch fillets to the EU. 
Table 11. Non-recurring and recurring costs of compliance for industrial fish processors:

\begin{tabular}{|c|c|c|c|c|c|}
\hline Plant & $\begin{array}{l}\text { Number of } \\
\text { Permanent/ } \\
\text { Temporary } \\
\text { Employees }\end{array}$ & $\begin{array}{c}\text { Value of Exports } \\
2002 \\
\text { (US\$) }\end{array}$ & $\begin{array}{c}\text { Current } \\
\text { Operating Level } \\
(\%)\end{array}$ & $\begin{array}{l}\text { Non-Recurring } \\
\text { Costs } \\
\text { (US\$) }\end{array}$ & $\begin{array}{c}\text { Increase in Unit } \\
\text { Production Costs } \\
(\%)\end{array}$ \\
\hline $\mathrm{A}$ & $\begin{array}{c}75 \\
100 \\
\end{array}$ & 10.73 million & 30 & 26,800 & 5 \\
\hline $\mathrm{B}$ & $\begin{array}{c}100 \\
80\end{array}$ & 1.86 million & 40 & 19,600 & 10 \\
\hline $\mathrm{C}$ & $\begin{array}{l}20 \\
40\end{array}$ & 0.54 million & 25 & 15,200 & 25 \\
\hline $\mathrm{D}$ & $\begin{array}{l}150 \\
250\end{array}$ & 2.59 million & 50 & 13,600 & 15 \\
\hline $\mathrm{E}$ & $\begin{array}{l}100 \\
150\end{array}$ & 0.32 million & 50 & 8,500 & 15 \\
\hline $\mathrm{F}$ & $\begin{array}{l}100 \\
200\end{array}$ & 0.38 million & 50 & 21,800 & 20 \\
\hline G & $\begin{array}{l}270 \\
250\end{array}$ & 12.83 million & 60 & 128,000 & 25 \\
\hline $\mathrm{H}$ & $\begin{array}{c}75 \\
100\end{array}$ & 4.27 million & 50 & 6,500 & 15 \\
\hline $\mathrm{I}$ & - & 0 & 0 & 80,000 & 30 \\
\hline $\mathrm{J}$ & - & 0 & 0 & 200,000 & 40 \\
\hline $\mathrm{K}$ & - & 0 & 0 & 2,100 & 40 \\
\hline $\mathrm{L}$ & - & 0 & 0 & 7,100 & 50 \\
\hline $\mathrm{M}$ & - & 0 & 0 & 19,500 & 25 \\
\hline $\mathrm{N}$ & - & 0 & 0 & 8,300 & 40 \\
\hline TOTAL & & 33.52 million & - & 557,000 & - \\
\hline Mean per plant & & & $44 \% *$ & 39,785 & 25 \\
\hline
\end{tabular}

*Operating plants only 
Recurring costs of operating to improve standards of hygiene and, in particular, an effective system of HACCP-based process control varied from 5 to 25 percent, with a mode of 15 percent (Table 11). Such variation is more difficult to explain. Differences in scale of operation are likely to influence these costs; the literature on the economics of HACCP suggests there are significant economies of scale (see for example Henson et al., 2000). Also, there may well be differences in the efficiency with which different processing operations have adjusted to new systems of production and control. However, respondents may also have differed in their ability to identify changes in production costs depending, for example, on their accounting procedures and/or degree to which written records are maintained of the processing operation. Where recurring costs of compliance were identified, these related to additional staff costs, for example employing a HACCP coordinator and quality control supervisors, additional laboratory testing both internally and using external facilities (for example KEBS), reductions in the rate of production to facilitate effective temperature recording, and greater packaging costs because of the need for pre-printing of the factory name.

The implementation of stricter standards of hygiene and HACCP-based process controls has also had a significant impact on the wider operations of industrial fish processing facilities. Two examples are changes in labour practices and the disposal of waste materials, as described below.

Historically, most processors have employed predominantly casual labour, particularly in more recent years when the supply of raw fish from Lake Victoria has become more sporadic and processing does not occur every day. However, in response to the need for fish handlers to undergo regular medical checks and be trained in basic hygiene practices, some have increased use of permanent and/or contracted labour. Temporary labour now tends to be used predominantly for tasks that do not involve contact with the fish, for example general cleaning operations.

Given that fish fillets are only 35 to 40 percent of the raw fish by weight, the volume of waste materials produced by industrial processing operations is considerable. The more rigorous standards of hygiene under which facilities now operated require that this material is disposed of both quickly and reliably to avoid any risk of cross-contamination of the raw fish (Jansen, 1997). Many processors have traditionally supplied these materials to artisanal fish processing operations situated in close proximity to their factory. However, these are not able to absorb the supply of frames and other materials the entire year round. Increasingly, therefore, processors are dealing with traders that collect in bulk and supply industrial fish meal plants. 


\section{Box 3. Costs of compliance for Plant 1:}

This company operates one Nile perch processing facility in Kenya and another in Uganda, although in the last two years it has taken control of three other factories, although these are still operating as separate enterprises. Its Kenyan facility has a capacity of 15 tonnes per day, although it is currently under renovation and not operational. The facility employs 150 people, of which 100 are in production.

Plant 1 sources around 60 percent of Nile perch through agents that operate at 11 beaches. The remainder is purchased directly from fishers. It provides boats, engines and nets via these agents in an effort to secure supplies of fish.

Although it has the capacity to produce fresh fish it is currently concentrating on frozen filets. Major markets include Japan (40\%), EU (in particular the Netherlands and Portugal) $(30 \%)$ and Australia (30\%). Prior to the ban on exports to the EU, 60-70 percent of its production was fresh filets which were exported to Germany and the Netherlands. However, the reputation of fresh Nile perch has not fully recovered and many buyers are wary. Further, although fresh filets are more profitable, they are also more risky. There is a possibility that it will restart production of fresh filets in the high season.

Plant 1 lost its export licence in 1998 and has since invested US\$13,600 to achieve compliance. These renovations were started prior to and during the ban and are currently on-going. The factory required new lighting and reorganisation to ensure effective separation of processing operations. An improved off-loading facility is also being constructed to ensure hygienic transfer of raw fish from trucks to the receiving area. Galvanised steel tables and recording temperature gauges have also been installed. A HACCP team is currently being employed and trained.

The recurring costs of compliance associated with these higher hygiene standards in all the facilities operated by Plant 1 is estimated to be around 15 percent of production costs. Additional costs include external laboratory tests for water at KEBS and pesticide residues at KEBS or the laboratory of the Government Chemist, more frequent internal microbiological tests (per batch rather than per day), more strict limits on chlorine in water used for processing operations and on-going staff training costs. Further, the costs of capital depreciation are significant.

Historically, the fish processing sector was unorganized; indeed there was little or no cooperation between individual companies even on an informal basis ${ }^{46}$. However, faced with ongoing restrictions on exports to the EU, fish processors recognised the need to present a single voice to the Government of Kenya and the European Commission. Individual processors were also concerned that they were being treated in a similar manner to the rest of the sector in terms of the requirements that were being imposed by the regulatory authorities (Mitullah, 1999). In response to these pressures industry organisations had evolved in Tanzania and Uganda; indeed a number of Kenyan processors were involved in these organisations through their sister

${ }^{46}$ Although the Fisheries Department had formed a Kenya Fish Processors Advisory Committee to address issues raised by EU inspectors in 1998 (Fisheries Department 1998). 
operations. In 2000, the Kenya Fish Processors and Exporters Association (AFIPEK) was formed.

The mission of AFPIEK is "To harmonise the highest quality standards in all member industries and promote marketing of Kenyan fisheries products". Currently it has 18 members, not all of which are operational and include both Nile perch and marine fish processors. It has a staff of two and is funded by member subscriptions. AFIPEK lobbies on behalf of the sector as a whole and attempts to co-ordinate the development of capacity, for example the provision of hygiene facilities at landing beaches, and training of fish handlers. Further, it is increasingly playing a role in ensuring orderly competition within the sector and planning for the sustainable promotion of the sector.

In December 2000, AFIPEK published a Code of Good Manufacturing Practice for the Handling and Processing of Fish and Fishery Products in Kenya (AFIPEK, 2000), with partial funding from UNIDO. The Code covers hygiene practices throughout the supply chain including fishing vessels, landing beaches, auctions, transport, and processing establishments. It aims to provide guidance for comply with EU and Kenyan legislation and is harmonised with similar codes developed in Tanzania and Uganda.

Currently, the Code is adopted on a voluntary basis by members and no register is kept to facilities that comply. The code is self-enforced with no requirement for external inspection, although AFIPEK does visit processing establishments periodically. Indeed, AFIPEK was called in by some members to undertake an inspection prior to the European Commission's mission in March 2002. Thus, the Code largely acts as a guidance document for compliance with regulatory requirements.

The Code has been criticised as being 'user unfriendly' and there are plans to translate the text into a series of booklets that provide practical set-by-step guides for each stage of the processing operation. It is estimated that the total cost would be in the region of US\$8,000. AFIPEK has also identified a need for a laboratory manual that can be used as the basis of on-site training in laboratory practice. The estimated cost is around US\$12,500.

Increasingly, the fish processing sector is Kenya is recognising the need to enhance the valueadded to Nile perch. Given the finite supply of raw fish and the level of excess capacity in the sector, there is a need to move away from exports of chilled or frozen fillets in bulk boxes towards, for example, portioning, breaded fillets or prepared fish dishes.

AFIPEK has recognised the constraints that the sector faces and is making efforts to enhance capacity. These include access to market information, development of expertise and know-how in product development, and facilitating access to new technologies. Currently, a project jointly funded by FAO, COMESA and CFC is exploring the possibilities for value-addition to Nile perch in the region. The ITC has also funded a visit to observe fish marketing in the UK, Switzerland, Belgium, Netherlands and Germany. 


\section{Box 4. Costs of Compliance for Plant 2:}

This company started operating as a quality butcher in 1969, although the family that now owns the business did not take over until 1978. Over the period 1978-93 it was the largest handler of livestock in Kenya. It no longer distributes meat, although there are plans to move back into the sector.

The company started to process fish in 1979. It was a small company until the period 1997 to 1999, when it expanded rapidly with the aim of covering East Africa as a whole. It currently has one plant in Kenya and two in Tanzania, and has plans to move into Uganda. Across these three plants it has 200 employees and an annual turnover of US\$50 million.

The plant has a capacity of 40 to 50 tonnes per day, although actual production averaged only 26.8 tonnes per day in 2002 and currently stands at 28.5 tonnes per day. It does not face great difficulties obtaining a reliable supply of fish at landing beaches, more significant are infrastructural and logistical problems getting the fish to the factory and its financial capacity to purchase Nile perch at current prices. Fish is sourced mainly via agents (currently 20 to 25 tonnes per day), but also directly from fishers. The Company has 80 vehicles that collect from 11 landing beaches. The factory receives 10-12 trucks of fish per day.

Major export markets are the EU (30\%), Japan (25\%), Australia (15\%) and the Far East $(5 \%)$. It has plans to increase/establish exports to the United States and Latin America. The ban on exports to the EU over the period 1997-2000 had a limited impact on the company, although it has been forced to diversify its export base and will avoid overreliance on the EU in the future. It was able to re-establish exports to the EU quite easily because it has an office in Portugal, indeed the Company's marketing and finance director lived in Portugal for some time.

In general, the processing facility is of a high standard and was the only facility to be approved by the Competent Authority and then re-approved following the EU inspection in 1998. Indeed, improvements had been made prior to the ban. It is estimated that the total cost of compliance with the stricter hygiene requirements was US\$128,000. This included the installation of a concrete pavement outside of the plant and improvements in the laboratory. The plant was the first in Kenya to implement HACCP. This was implemented internally by a member of the family. The operation of the facility under HACCP has required the employment of extra quality control staff, record-keeping and analysis. It is estimated that this has added 25 percent to production costs. 


\subsection{Landing beaches}

The impact that stricter hygiene and other food safety requirements have had on landing beaches and the success of efforts to enhance capacity must be viewed in the context of the prevailing physical and management infrastructure along the shores of Lake Victoria. Generally, fishing communities are characterised by severe infrastructural constraints, whilst efforts to effect sustainable management of the fishery in a manner that is inclusive of local interests have been largely ineffective.

\section{Box 5. Costs of compliance for Plant 3:}

This plant is owned by a company that also operates bakeries and hotels. It started processing Nile perch in 1992 and currently operates one facility with a capacity of nine tonnes per day. This is currently operating at five tonnes per day for four days per week because of problems obtaining a sufficient supply of fish. The facility currently has 75 permanent employees.

Fish is sourced through agents that operate on five beaches. The Company provides a truck and ice to ensure reliable transportation of fish to the processing facility. Agents are paid an agreed price at the factory. Periodic checks are made at the beaches to ensure the price being paid is 'reasonable'. Agents that have been used for a long time are provided with funds to purchase fish, although to a maximum of 50 percent of the purchase value.

Prior to the restrictions on exports, 70 percent of exports were to the EU, with other less important markets including Japan, United States, Latin America, Middle East and China. However, since the ban it has not attempted to export to the EU and major markets are now Japan, China, Middle East and the United States.

The Company has had to make significant changes to its processing facility in order to comply with current hygiene requirements. These include the installation of partitioning and revisions to the layout of the factory to ensure segregation of operations, new tables and other equipment, up-grading of the laboratory, recording thermometers and on-line chlorination. Further the costs of implementing HACCP and staff training have been significant. The total cost is estimated to be US $\$ 26,800$.

The Company has also made changes to its production process, including new sanitation regimes. More quality control staff have been employed (there is now a quality control manager and five supervisors) and processing staff have been assigned to particular operations for which they have been trained, reducing flexibility. The speed of work has also declined because of the need to implement and monitor temperature controls. Further, more samples are required that are sent to KEBS for analysis. Overall, the increase in costs of production is estimated to be 5 percent.

Overall, the management of the Lake Victoria fishery has been characterised by ineffective institutions and poor enforcement and implementation of legal controls under the Fisheries Act (McCormick and Mitullah, 2002). Further, in general Fisheries Department staff is poorly paid and there is a lack of an enabling environment in which they can undertake their duties (Geheb, 
1997). Whilst attempts have been made to implement more effective management, these have tended to lack co-ordination and frequently multiple institutions have co-existed that overlap and even conflict in their responsibilities and actions.

It is evident that the ban on exports of Nile perch to the EU has served to focus attention on the need for better management of the fishery and, in particular, the importance of co-management in which local communities have an integral role. Indeed, the Kenya Development Plan issued in 2002 has co-management as a priority (GOK, 2002). Further, fishers are increasingly seen as central to the development of infrastructure and the effective management of both the fishery and landing beaches, even amongst fish processors.

The capacity of fishing communities to up-grade capacity has further been compromised by the lack of fundamental infrastructure at most landing beaches, in turn reflecting lack of investment over the longer term (Ong'ang'a, 2002). Access roads are frequently in poor condition or missing altogether, limiting access to alternative markets and creating quality problems as a result of the considerable period of time taken for trucks to get from landing beaches to processing facilities. In most cases there are is little or no access to running water and toilet and other sanitation facilities are rudimentary at best.

In all of its inspection reports the European Commission has identified weaknesses in hygiene standards at landing beaches (European Commission, 1998; 1999; 2003). Key infrastructural requirements include toilets, potable running water, perimeter fence around the banda where fish is traded, and paving from the edge of the lake to the banda. Ideally, fish would be landed onto a jetty to avoid contact with water along the shoreline which is invariably polluted. In its most recent report, the Commission requested written assurances on beach improvements and a specified timeline during which these would be implemented.

Initially, the Fisheries Department established a Landing Beach Development Committees (LBDC) to plan and co-ordinate improvements at each landing site with a view to achieving acceptable standards (Fisheries Department, 2002). These included District Fisheries Officers, Public Health Officers, Beach Leaders and/or community chiefs, and representatives of fish processors. However, LBDCs did not work well, most notably because of a lack of effective representation of fishers and attempts to impose solutions to capacity problems on local communities.

More recently, the Fisheries Department has established a Lake Victoria Beach Improvement Committee that has identified priority beaches (see below) and the required improvements to meet EU hygiene standards. Currently, this has officials from the Fisheries Department and representatives of industrial fish processors, but not local fishing communities. For each of the identified beaches a Beach Improvement Unit (BIU) has been established under the leadership of a fisheries officer. The Fisheries Department has also trained 20 beach inspectors to manage handling of fish and ensure good hygiene on a day-to-day basis. Efforts have also been made to sensitise fisher-folk in the importance of good hygiene and management of the fishery.

The Fisheries Department has identified a number of minimum basic facilities that allow hygienic handling of fish at each beach: 
- Paving and provision of proper drainage at sorting sheds and loading zones.

- Perimeter fencing to exclude animals and human activities not related to the fish business.

- Provision of potable water.

- Improvement of sorting sheds, with adequate fish sorting tables.

- Provision of adequate sanitation facilities.

- Provision of adequate insulated fish boxes, with ice for fish collection.

- General cleanliness of the beach.

- Provision of anaerobic digestor toilets.

A series of further improvements has also been identified that would ensure standards of hygiene are compliant with EU requirements and otherwise promote good standards of hygiene and quality in the supply chain:

- Provision of electricity and water.

- Construction of landing jetties.

- Modernization of fish reception bandas.

- Improvement of access roads.

- Construction of ice plants/cold rooms.

Figure 27. Improved banda at Dunga beach:

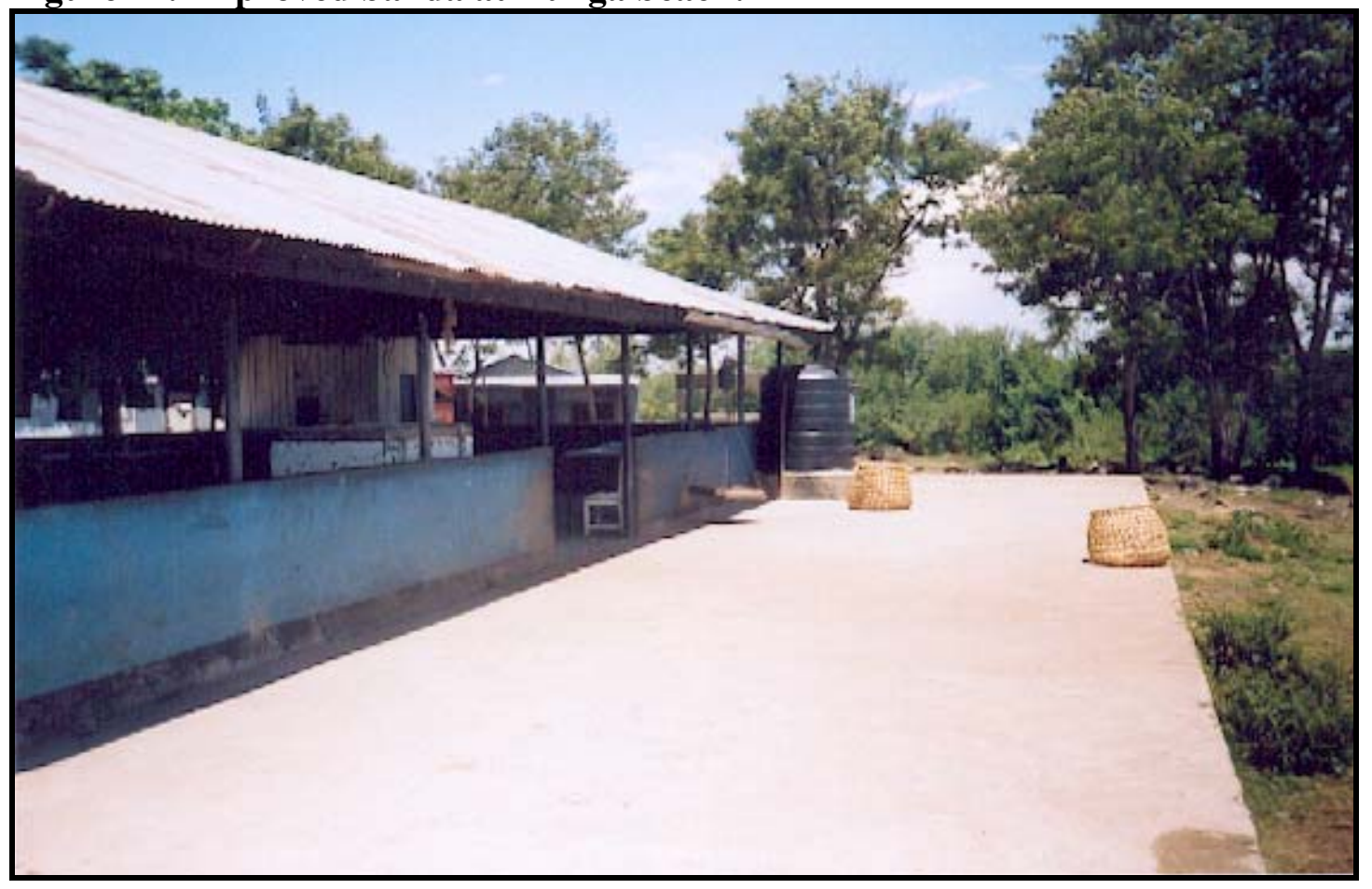

Various estimates have been made of the cost of beach improvements to meet the standards of hygiene required by EU standards. For example, McCormick and Mitullah (2002) suggest the cost is as great as US\$1.2 million. However, it is evident that there has been a tendency to overestimate these costs, perhaps as part of efforts to attract more significant donor support. However, the Fisheries Department and/or AFIPEK estimate that the cost of basic beach improvements to be around US $\$ 99,000$ per beach and a further US\$225,000 for extended 
improvements (Table 12). Perhaps the scale of the required funding (and the magnitude of the estimates) explains why only limited progress has been made to date. Indeed, the Fisheries Department has identified the need for an integrated approach involving funding from the Government of Kenya, fish processors, local communities and donors (DF, 2001). A draft joint proposal by stakeholders representing BICs, BMUs and the Fisheries Department on Infrastructural Development of Fish Landing Sites in Kenya has subsequently been developed.

A number of investments have been made in beach improvements, although these have not always been co-ordinated effectively and have proceeded in a piecemeal fashion with funding through a variety of donors. Box 6 and Figure 27 provide illustrations of some improvements that have been made to date and confirm the widely varying standards that remain across individual landing sites.

Table 12. Estimated average cost of landing beach improvements:

\begin{tabular}{|l|c|}
\hline \multicolumn{1}{|c|}{$\begin{array}{c}\text { Improvement } \\
\text { Basic Requirements } \\
\text { (US\$) }\end{array}$} \\
\hline Fencing & 6,400 \\
\hline Banda & 51,300 \\
\hline Potable water supply & 6.400 \\
\hline Fish handling equipment & 3,200 \\
\hline Paving & 25,600 \\
\hline Toilets & 3,800 \\
\hline Cold boxes & 3,800 \\
\hline Sub-total & 100,500 \\
\hline \multicolumn{2}{|c|}{ Further Improvements } \\
\hline Cold room & 44,900 \\
\hline Electricity supply & 51,300 \\
\hline Ice making plant & 51,300 \\
\hline Access road upgrading & 38,500 \\
\hline Landing jetty & 38,000 \\
\hline Sub-total & 224,500 \\
\hline
\end{tabular}

Source: Fisheries Department; AFIPEK

The LVEMP, for example, has invested in some improvements at landing beaches. Most notably, a stone banda with tables and a store has been established at Mbita beach at a cost of US\$1.03 million. However, this beach is still in need of a perimeter fence and cooling facilities. Some fencing has been provided for other beaches. 


\section{Box 6. Improvements at Mainuga beach:}

Mainuga beach has a total of 154 boats, including eight motorised craft, three of which are for fishing. Fishers are organised into two self-help groups, one established in 1992 and the other in 2000. These groups deal directly with agents of the industrial fish processors. A cooperative existed at the beach until 1997 when it ceased operating. Although the fisher groups compete with one another, and this is seen as a good thing, they are brought together for the effective management of the beach by the BMI.

Three industrial fish processor normally source from the beach through their agents, which deal directly with the fisher groups. All bring trucks to the beach to collect fish. One processor also has a boat with an ice box and lands fish from other beaches for collection by its truck. None of the processors provide any equipment or loans to the fisher groups.

The facilities at the beach are rudimentary. There is a concrete banda, although this in need of repair (for example windows and flooring slabs need replacing). It has no running water and is not fenced. There are no cold storage facilities and the toilet facilities are inadequate. The area between the water and the banda is not paved. The access road to the beach is also in need of improvement.

The two fisher self-help groups provide 20 percent of their income to the BMU for beach improvements. To date, they have installed toilets and improved the access road. The BMU is now beginning to construct a perimeter fence around the banda on a step-by-step basis. The BMU has also received funds from a donor to purchase improved fishing gear, which will be supplemented with an additional 60 percent from the community.

It is evident that most fishers at the beach know the correct procedures for handling fish and the up-grading that is required at the beach. For example, fish is transported from boats to the banda in wheelbarrows. Indeed, the community has had a lot of training and exposure to other beaches through a local NGO. The key constraint is funding to implement the required improvements.

The industrial fish processing sector is aware of the remaining and significant lack of hygiene standards at landing beaches and the potential threat this poses to their own interests. Indeed, AFIPEK has established a Beach Development Fund with contributions from its membership. Investments have been made in perimeter fencing and improvements in bandas. However, its efforts have been hampered by the differing attitudes of its members to the importance and/or responsibility for beach improvements. Whilst some industrial fish processors have given significant contributions, others remain indifferent or even hostile.

Two fish processors have invested directly in the development of facilities at landing sites. A jetty, fencing and banda have been constructed at Port Victoria at a total cost of US\$9,000. Further, improvements costing US\$ 19,200, including the construction of a jetty, fencing toilet and/or banda, have been made at Mbita-Rusinga, Uhanaya and Marenga. Such initiatives, however, remain the exception rather than the rule. 
AFIPEK is currently undertaking an assessment of critical needs at landing beaches and will base its further work on the identified priorities. However, it is concerned about the efficacy of beach management and the degree to which the fish processing sector has an influence on the future direction of beach management. It is of the view that funding should be provided by all stakeholders, namely government, fish processors and fishers, and this should be co-ordinated through a tripartite management structure. AFIPEK is reluctant to make any further investments until this is in place. We have to recast this statement in the context of the draft proposal.

Recognising the resource constraints under which it is operating and the need to effect the enhancement of standards in a limited period of time, the Fisheries Department has identified 13 beaches that will be improved to EU standards (Table 13) (Gitonga et al., 2000; Fisheries Department, 2001a; 2001b). Collectively, these beaches account for the bulk of fish purchased by industrial fish processors. The aim is to implement a system of beach health certificates whereby all exports would have to be derived from certified beaches. Further, each beach will be given a reference number to enhance traceability of fish back to the individual landing beach. Due to financial constraints efforts are currently being focused on ten beaches.

Table 13 details the improvements made at these 13 beaches. On most beaches some improvements been made, including the construction of toilets, fencing and a banda. However, most remain unpaved and do not have access to potable water. The estimated cost of the improvements made to date at four beaches is as follows:

- Uhanya: US $\$ 256,000(60 \%$ of required improvements)

- Usenge US\$11,500 (40\% of required improvements)

- Karungu: US\$8,400 (57\% of required improvements)

- Nyanguena: US\$6,500 (55\% of required improvements)

\subsection{Wider supply-chain effects}

The imposition of stricter standards for hygiene and controls on pesticide residues for fish and fishery products has also influenced the structure and modus operandi of the supply chain. In part this reflects the existing challenges facing the Nile perch fishery, in particular the inability of industrial fish processors to secure sufficient supplies of fish to operate at or near to capacity and the decline in returns within local fishing communities as a result of the expansion in number of fishers. However, it is also a manifestation of the lack of cooperation in the sector, particularly amongst industrial fish processors, and the absence of any real efforts to co-ordinate and/or to manage the growth of the sector.

The EU standards for fish and fishery products lay down requirements that encompass the entire supply chain. Further, they require that processors institute 'own checks' such that they have full control of the production process from the in-coming raw fish to the finished product. For example, processors must ensure that the fish they purchase is cooled as soon as possible after capture and remains so through to the factory gate. Given that there are virtually no chilling facilities at landing beaches, processors have to provide ice and insulated trucks. Whilst they incur significant costs as a result, it also enhances their market power over fishers. In essence, the value of a fisher's catch is now dependent on timely access to cooled storage. Where the only source of ice is a processor or their agent, fishers may have little choice but to sell their catch regardless of the offer price. Whilst this may be offset by competition between processors 
that themselves need to secure an adequate supply of fish, everything else being equal, it acts to diminish the bargaining power of fishers.

Table 13. Beaches identified for improvement by Fisheries Department, August 2003:

\begin{tabular}{|c|c|c|c|c|c|c|c|c|c|}
\hline Beach & District & 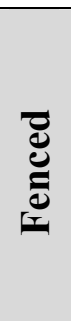 & 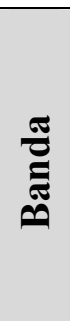 & $\sum_{0}^{2}$ & $\underset{\Xi}{\mathbb{Z}}$ & $\stackrel{\frac{0}{0}}{\frac{0}{\theta}}$ & 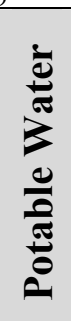 & 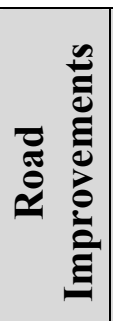 & 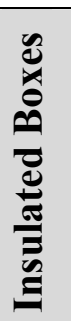 \\
\hline Uhanya & Bondo & $\checkmark$ & $\checkmark$ & $x$ & $\checkmark$ & $\checkmark$ & $\checkmark$ & $\checkmark$ & $\checkmark$ \\
\hline Mbita & Suba & $\checkmark$ & $\checkmark$ & $x$ & $x$ & $\checkmark$ & $x$ & $\checkmark$ & $\checkmark$ \\
\hline Nyangwena & Migori & $\checkmark$ & $\checkmark$ & $x$ & $x$ & $\checkmark$ & $x$ & $x$ & $\checkmark$ \\
\hline Kaloka & Kisumu & $\checkmark$ & $\checkmark$ & $x$ & $x$ & $\checkmark$ & $x$ & $\checkmark$ & $\checkmark$ \\
\hline Bumbe & Busia & $\checkmark$ & $x$ & $x$ & $x$ & $\checkmark$ & $x$ & $x$ & $x$ \\
\hline Wich lum & Bondo & $x$ & $\checkmark$ & $x$ & $x$ & $\checkmark$ & $x$ & $\checkmark$ & $\checkmark$ \\
\hline Dunga & Kisumu & $\checkmark$ & $\checkmark$ & $\checkmark$ & $\checkmark$ & $\checkmark$ & $\checkmark$ & $\checkmark$ & $\checkmark$ \\
\hline Kendu Bay & Rachuonyo & $\checkmark$ & $\checkmark$ & $x$ & $x$ & $\checkmark$ & $x$ & $\checkmark$ & $x$ \\
\hline Marenga & Busia & $\checkmark$ & $\checkmark$ & $x$ & $x$ & $\checkmark$ & $\checkmark$ & $x$ & $\checkmark$ \\
\hline Luanda-Kotieno & Bondo & $x$ & $\checkmark$ & $x$ & $x$ & $\checkmark$ & $x$ & $\checkmark$ & $\checkmark$ \\
\hline Karungu & Migori & $\checkmark$ & $\checkmark$ & $\checkmark$ & $\checkmark$ & $\checkmark$ & $x$ & $x$ & $\checkmark$ \\
\hline Usenge & Bondo & $\checkmark$ & $\checkmark$ & $x$ & $x$ & $\checkmark$ & $x$ & $\checkmark$ & $x$ \\
\hline Koginga & Homa Bay & $\checkmark$ & $\checkmark$ & $x$ & $x$ & $\checkmark$ & $\checkmark$ & $x$ & $x$ \\
\hline
\end{tabular}

The imposition of stricter hygiene standards is also accelerating rationalisation of the industrial fish processing sector in Kenya, a process which had begun in the mid to late 1990s. Whereas 15 facilities have been constructed near to Lake Victoria or in Nairobi, only nine are currently operational. Of these, most are operating at less than 60 percent capacity (Figure 33). Indeed, currently only 38 percent of the installed capacity in the sector as a whole is operational. Further, the ownership of processing facilities is becoming more concentrated - the nine facilities that are currently active are operated by only six companies. This is likely to enhance further the market power of the processing sector over fishers.

The stricter hygiene requirements imposed on the Nile perch sector has created a mutual dependency between individual participants, both within the processing sector and between the processing sector and the fishing communities. Continued compliance with these requirements is dependent upon the development and maintenance of capacity at all levels of the supply chain. Non-conformity at any stage could potentially result in food safety problems and reinstatement of restrictions on exports. Thus, AFIPEK is the first real attempt by the industrial fish processors to cooperate and create a strategic focus for the future development of the sector. Further, fish processors have become involved in the development of in structure on landing beaches. There is also renewed interest in the effective management of the Lake Victoria fisheries based on the effective participation of local communities. It is doubtful whether many of these initiatives would have been forthcoming, at least in the short to medium term, in the absence of the shock imposed on the supply chain by the actions of the EU. 


\section{CONCLUSIONS}

The case of Nile perch exports to the EU illustrates the significant effects that the imposition of food safety requirements can have on export-oriented supply chains in a developing country context. It also highlights the restructuring of food safety controls and related investments required in order to maintain access to industrialized country markets. Thus, developing countries are being required to make choices between the markets they serve. On the one hand are markets in other developing countries, many of which are expanding rapidly and currently have less strict food safety standards. On the other hand are markets in industrialized countries that are generally high value but require compliance with increasingly strict food safety requirements.

The Nile perch fishery developed rapidly though the 1980s and 1990s, transforming an artisanal and locally-oriented sector into a global commodity chain. Both the scale of the fishery and the nature of the processing sector changed dramatically, although the basic characteristics of the fishing communities remained largely unchanged and there was very limited investment in upgrading food safety capacity. During the later 1990s, the supply chain began to face constraints associated with the sustainability of the fishery as the landed catch stabilized and even began to decline. Thus, the imposition of more strict food safety requirements on the supply chain served to exacerbate existing pressures for restructuring and reform, while prevailing supply and capacity issues constrained the manner in which the various levels of the chain were able to respond.

This case can be sub-divided into two related elements. The first element was the general need to upgrade hygiene standards to maintain access to EU markets over the period since 1991. The second element was the need to address specific compliance issues in order to overcome specific restrictions on exports to the EU during the period 1997-2000. The response by the Government of Kenya and the Nile perch supply chain is summarized in Figure 28. It is evident that the predominant compliance strategy was both reactive and defensive. Indeed, there is only limited evidence of any proactive response to the imposition of more strict hygiene requirements within the EU. Further, the problems faced by the sector reflected, at least in part, the limited investment that had been made in food safety controls despite the progressive export orientation of the supply chain. Rather, much of the concerted effort to comply with EU requirements was stimulated by the loss of market access as a result of specific measures that prohibited exports from Kenya, Tanzania and Uganda. The response can thus be more generally characterized as 'crisis management'.

The specific restrictions on exports of Nile perch to the EU over the period 1997-2000 had a significant impact at both the macro and micro levels. Exports initially declined, reflecting the loss of Kenya's most significant export market, although exporters soon began to exploit alternative markets and by 2001 the overall volume of exports had recovered. Many fish processing facilities were forced to close, at least in the short term, or operated at low levels of capacity. The resultant decline in demand for Nile perch led to a reduction in the landed price to fishers and a fall in the aggregate income to local fishing communities. However, this soon recovered, at least in part, as processors competed to secure supplies of fish in order to boost production. 
The regulatory regime of the EU is distinct from those in other major exports markets for Nile perch, most notably Japan, Australia and the United States, although many of its basic elements are comparable. In particular, the prominent role of the 'competent authority' in implementing and maintaining standards that are at least equivalent to those in the EU creates a mutual dependency between exporters and public regulatory authorities. Although it reduces the risks of rejection associated with border inspection in export markets, it also requires considerable capacity on the part of regulatory authorities in developing countries, which is often lacking and costly to implement. Indeed, a number of countries, not only developing but also industrial states, have struggled to comply with EU requirements, some of which have still been unable to secure market access.

Figure 28. Nature of compliance strategies relating to hygiene and other food safety requirements for Nile perch:

\begin{tabular}{|c|c|c|}
\hline & Reactive & Proactive \\
\hline 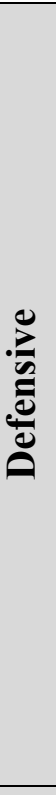 & $\begin{array}{l}\text { Legislative change to harmonise with } \\
\text { EU standards. } \\
\text { Up-grading of hygiene standards in } \\
\text { industrial processing facilities to } \\
\text { comply with EU requirements. } \\
\text { - Trade diversion and /or diversification } \\
\text { of export markets to offset access } \\
\text { problems with EU markets. } \\
\text { Efforts to enhance standards of } \\
\text { hygiene at landing beaches in response } \\
\text { to European Commission inspection } \\
\text { reports. } \\
\text { Reform and up-grading of domestic } \\
\text { controls on fish processing facilities in } \\
\text { response to European Commission } \\
\text { inspection reports. }\end{array}$ & $\begin{array}{l}\text { Efforts by some industrial fish } \\
\text { processors to up-grade hygiene } \\
\text { standards prior to implementation of } \\
\text { EU requirements. } \\
\text { - Coordination of regulatory activities } \\
\text { across East Africa to avoid future } \\
\text { problems with compliance. }\end{array}$ \\
\hline$\underbrace{\infty}_{0}$ & $\begin{array}{l}\text { - Bilateral negotiations with European } \\
\text { Commission regarding EU } \\
\text { requirements, particularly relating to } \\
\text { controls on pesticide residues. }\end{array}$ & \\
\hline
\end{tabular}


It is evident that standards of hygiene in the fish and fishery products sector were significantly below those required by EU legislation at the time the first restrictions were applied to exports in 1996-97. The Competent Authority was unable to implement an effective regime of inspections of processing facilities and certification of export consignments. Laboratory facilities were not of the required standard to provide tests that could be generally regarded as valid and reliable. Standards of hygiene in parts of the fish processing sector and at landing beaches did not conform with EU requirements, both in terms of specific structural and/or procedural requirements or the implementation of 'own checks'. To a large extent this reflected a more general lack of food safety capacity in both the public and private sectors; the basic elements were in place, these were generally outdated and far below international standards.

Kenya, more than Tanzania and Uganda, has struggled to comply with EU requirements relating to hygiene and controls on pesticide residues for fish and fishery products. Hence, it was the last of the three countries to achieve a lifting of the ban on exports of Nile perch relating to controls on pesticide residues. Further, although both Tanzania and Uganda are now fully harmonized with EU requirements and included in Part I of the list of approved third countries, currently Kenya remains in Part II. To a large extent this reflects the overly bureaucratic and disjointed administrative structure for the regulation of the fish and fishery sector that prevailed until 2000. This has since been reformed and much has been achieved.

The government of Kenya has invested heavily in changes to legislation and administrative structures, reinforcement of inspection and certification procedures, upgrading of laboratory facilities, and training of personnel. While the costs have been considerable, the benefits in terms of the better control and more effective control of the sector are apparent. Although further efforts are needed to reform management of the Lake Victoria fishery and the control of landing beaches, initiatives are underway and are beginning to bear fruit.

Standards of hygiene in the fish processing sector were variable when restrictions were first applied on exports to the EU. While some facilities were close to EU requirements, others had major non conformities. Thus, some companies have been forced to invest heavily in upgrading their factories, implementing HACCP and/or other procedures, enhancing laboratory testing facilities, etc. The total cost of these investments is estimated at US\$557,000, with an average cost per plant of US\$39,785. Further, there has been some increase in production costs, albeit limited, associated with the need to undertake enhanced testing regimes, temperature recording, record-keeping, staff training, etc. On average, production costs are estimated to have increased 25 percent as a direct result of the imposition of more strict food safety standards.

Although efforts have been made to enhance standards of hygiene at landing beaches, basic infrastructure is still lacking. Indeed, many beaches do not posses even basic sanitary amenities such as running potable water and washing facilities. To a large extent this reflects the fact that, until restrictions were applied on exports to the EU, little investment had been made in local fishing communities despite the economic success of Nile perch exports. Further, management of the fishery has been in disarray for many years, and local communities frequently have not been empowered to take charge of the development of the beaches where they live and work. It is evident that the resources required to make the necessary improvements to the infrastructure 
and hygiene standards of landing beaches are considerable and this remains the key challenge for the government of Kenya, fish processors and fisher-folk.

The application of more strict hygiene requirements on exports of Nile perch to the EU and, more specifically, the imposition of restrictions on exports through the period 1997-2000 have had profound effects on the sector and its course of evolution. Whereas the export supply chain for Nile perch developed with a central focus on EU markets, today most exporters have diversified their export base and have major markets in, among others, Australia, Japan and the United States. However, ironically, compliance with EU requirements has better enabled Kenyan exporters to access and maintain these markets. Indeed, a number of exporters highlight the fact that they are asked if they are approved for export to the EU when approaching new customers throughout the world. Thus, while the processing sector will undoubtedly be smaller in the future, it will also be fitter.

An on-going issue is the management of the Lake Victoria fishery and its future exploitation in a sustainable manner. Historically, the management of the fishery has been largely ineffective and the Nile perch supply chain has evolved in a laissez faire manner. Further, the processing sector has been characterized by a lack of cooperation and indeed hostility between individual companies. The need to comply with EU hygiene and pesticide control requirements, however, has served to highlight the need for more effective cooperation and coordination both horizontally and vertically within the supply chain. Thus, AFGIPEK was established to represent the interests of the fish processing sector. Further, initiatives are underway to engender co-management of the Lake Victoria fishery.

The governments of Kenya, Tanzania and Uganda have also cooperated more actively in the management of Lake Victoria and compliance with EU food safety requirements. The Lake Victoria Fisheries Organization (LVFO) comprises the fisheries departments and research institutes of the three countries. The Fisheries Management Committee of LVFO, for example, has recommended that regulations of the three countries be harmonized and that border areas should be monitored by joint patrols to prevent the landing of fish from foreign waters.

The economic costs of compliance with EU food safety requirements for fish and fishery products and the impact of restrictions on exports from Kenya have clearly been considerable. As a result, compliance has been achieved and access to EU markets reinstated, while more generally the supply chain is better able to compete in global market places. However, challenges remain. On the one hand, the supply chain must continue to maintain and enhance standards of hygiene and food safety control more generally so as to be prepared for the future evolution of requirements in export markets. On the other, much still needs to be done to enhance infrastructure and capacity at landing beaches.

The impression provided by the most recent inspection report of the European Commission is that the approach in Kenya is to 'deal with a problem and then forget'. This conforms to the reactive and defensive approach to compliance characterized in this paper. The risks and costs associated with such an approach, however, are illustrated by the very experiences of Kenya over the period 1997-2000. In a world where food safety standards are being revised and upgraded seemingly continuously, it is important to be proactive, both in terms of monitoring change and 
reacting to it. Further, the upgrading of food safety capacity must be seen as an essential element of efforts to expand export trade performance. 


\section{REFERENCES}

Abila, R.O. (1995). Structure, Conduct and Performance of Kisumu Fish Marketing System. MSc Thesis, University of Nairobi.

Abila, R.O. (1996). Economic Analysis of the Domestic and Export Marketing of Kenya's Nile Perch and its Products. Proceedings of $6^{\text {th }}$ FAO Expert Consultation on Fish Technology in Africa, Kisumu.

Abila, R.O. (1998). Four Decades of the Nile Perch Fishery in Lake Victoria: Technological Developments, Impacts and Policy Options for Sustainable Utilisation. Paper presented at the workshop Prospects for the Sustainable management of Lake Victoria, Mwanza.

Abila, R.O. (2000). The Development of the Lake Victoria Fishery: A Boon or Bane for Food Security? IUCN, Nairobi.

Abila, R.O. (2002). A Socio-Economic Analysis of the Fishery Cooperatives of Lake Victoria (Kenya). PhD Thesis, University of Hull.

Abila, R.O. and Jansen, E.G. (1997). From Local to Global Markets: The Fish processing and Exporting Industry on the Kenyan Part of Lake Victoria: Its Structure, Strategies and SocioEconomic Impacts. Centre for Development and the Environment, University of Oslo, Oslo.

Abila, R.O. and Jansen, E. (1997). From Local to Global markets: The Fish Processing and Exporting Industry on the Kenyan Part of Lake Victoria: Its Structure, Strategies and SocioEconomic Impacts.

AFIPEK (2000). Code of Good Manufacturing Practice (GMP) for the Handling and Processing of Fish and Fishery Products in Kenya. Kenya Fish Processors and Exporters Association, Nairobi.

Bankole, A., Ogunkoba, O. and Ademola Oyejide, T. (2000). Quantifying the Trade Impact of Sanitary and Phytosanitary Standards: What is Known and Issues of Importance for SubSaharan Africa. World Bank, Washington DC.

Bokea, C. and Ikaiara, M. (2002). The Macroeconomy of the Export Fishing Industry in Lake Victoria (Kenya). IUCN, Nairobi.

Cato, .C. (1998). Seafood Safety - Economics of Hazard Analysis and Critical Control Point (HACCP) Programmes. FAO, Rome.

Cato, J.C. and Lima dos Santos, C.A. (1998a). Costs to Upgrade the Bangladesh Frozen Shrimp Processing Sector to Adequate Technical and Sanitary Standards and to Maintain a HACCP Program. NE-165, University of Massachusetts, Amhurst. 
Cato, J.C. and Lima dos Santos, C.A. (1998b). European Union 1997 Seafood Safety Ban: The Economic Impact on Bangladesh Shrimp Processing. Marine Resource Economics, 13 (3), 215227.

CBS (2002). Economic Survey 2002. Central Bureau of Statistics, Nairobi.

Delgado, C.L., Wada, N., Rosegrant, M.W., Meijer, S. and Ahmed, M. (2003). Fish to 2020: Supply and Demand in Changing Global Markets. International Food Policy Research Institute, Washington DC.

Delgado, C.L., Wada, N., Rosegrant, M.W., Meijer, S. and Ahmed, M. (2003). Outlook for Fish to 2020: Meeting Global Demand. International Food Policy Research Institute, Washington DC.

European Commission (1998). Final Report on a Mission to Kenya: Fisheries Products, 23 to 27 November 1998. European Commission, Brussels.

European Commission (1999). Final Report on a Mission to Kenya: Fisheries Products, 16 to 18 August 1999 for the Purposes of the Assessment of Control of Pesticide Residues in Fish Coming from Lake Victoria.. European Commission, Brussels.

European Commission (2003). Final Report on a Mission carried Out in Kenya 14 to 22 March 2002 Carried Out to Assess the Conditions of Production of Fisheries products( Council Directive 91/493/EEC) and the Verification of the Measures on Pesticides in Fish. European Commission, Brussels.

FAO (1995). Development of Small-Scale Fish Farming in the Lake Basin: Kenya Phase 2 Project Findings and Recommendations. Food and Agriculture Organization, Rome.

FAO (1999). The Importance of Food Quality and Safety for Developing Countries. Committee on World Food Security, FAO, Rome.

FAO (2000). The State of World Fisheries and Aquaculture 2000. Food and Agriculture Organization, Rome.

FAO (2002). The State of World Fisheries and Aquaculture 2002. Food and Agriculture Organization, Rome.

Ferguson, A.E., Derman, B. and Mkandawire, R. (1990). The New Development Rhetoric and Lake Malawi. Africa, $\underline{63}$ (1), 1-18.

Fisheries Department (1995). 1995 Annual Statistical Bulletin. Fisheries Department, Nairobi.

Fisheries Department (1996). 1996 Annual Statistical Bulletin. Fisheries Department, Nairobi.

Fisheries Department (2000). Frame Survey 2000 Report. Fisheries Department, Nairobi. 
Fisheries Department (2001a). Report on Handling, processing and Marketing of Fish in Kenya: progress Towards Compliance with National and International Fish Quality and Safety Standards February 2001. Fisheries Department, Nairobi.

Fisheries Department (2001b). Report on Handling, processing and Marketing of Fish in Kenya: progress Towards Compliance with National and International Fish Quality and Safety Standards July 2001. Fisheries Department, Nairobi.

FDA (2002). FDA's Evaluation of the Seafood HACCP program for Fiscal Years 2000/2001. US Food and Drugs Administration, Washington DC.

Francis, E. and Hoddinott, J. (1993). Migration and Differentiation in Western Kenya: A tale of Two Sub-Locations. Journal of Development Studies, 31, 1, 29-42.

Geheb, K. (1997). Regulators and Regulated: Fisheries Management Options and Dynamics in Kenya's Lake Victoria Fishery. PhD Thesis, University of Sussex,

Geheb, K. and Binns, T. (1997). 'Fishing Farmers' or 'Farming Fishermen'? The Quest for Household Income and Nutritional Security on the Kenyan Shores of Lake Victoria. African Affairs, 96, 73-93.

Gibbon, P. (1997). Of Saviours and Punks: The Political Economy of the Nile Perch Marketing Chain in Tanzania. Centre for Development Research, Copenhagen.

Gitonga, N.K., Okal, L. And Mutegi, E. (2000). Effect of EU Bans on Kenya Fisheries. Fisheries Department, Nairobi.

Globefish (1998). The Japanese Seafood Market. Food and Agriculture Organization, Rome.

Globefish (2000). European Union Standards for Fishery Products. Food and Agriculture Organization, Rome.

GOK (2002). Development Plan 2002-2008. Government of Kenya, Nairobi.

Goulding, I. (1997). Perch on a Precipice. SeaFood International, April,

Greboval, D. and Mannini, P. 91992). The Fisheries of Lake Victoria: Review of Basic Data. $U N D P / F A O$ Regional Project for Inland Fisheries Planning Development and Management in Eastern/Central/Southern Africa. FAO, Rome.

Harris, C.K., Wiley, D.S. and Wilson, D.C. (1998). Socio-Economic Impacts of the Introduction of Foreign Species into Lake Victoria Fisheries. In: Pitcher, T.J. and Hart, P.J.B. (eds). The Impact of Species Change in African Lakes. Chapman and Hall, London. 
Henson, S.J., Loader, R.J., Swinbank, A., Bredahl, M. and Lux, N. (1999). Impact of Sanitary and Phytosanitary Measures on Developing Countries. Department of Agricultural and Food Economics, The University of Reading.

Henson, S.J., Brouder, A-M. and Mituulah, W. (2000a). Food Safety Requirements and Food Exports from Developing Countries: The Case of Fish Exports from Kenya to the European Union. American Journal of Agricultural Economics, $\underline{82}$ (5), 1159-1169.

Henson, S.J. and Holt, G. (2000b). Exploring Incentives for the Adoption of Food Safety Controls: the case of HACCP in the UK dairy sector. Review of Agricultural Economics, 22 (2), 407-420.

Hoekstra, T.M., Asila, A., Raburu, C. and Rambiri, O. (1991). Report on a Census of Fishing Boats and Gear in the Kenyan Waters of Lake Victoria. FAI, Rome.

Ikiara, M. (1999). Sustainability, Livelihoods, Production and Effort Supply in a Declining Fishery: the Case of Kenya's Lake Victoria Fishery. PhD Thesis, Amsterdam.

Jaffee, S. (2003). From Challenge to Opportunity: The Transformation of the Kenyan Fresh Vegetable Trade in the Context of Emerging Food Safety and Other Standards. World Bank, Washington DC.

Jansen, E. (1997). Rich Fisheries-Poor Fisherfolk: The Effects of Trade and Aid in the Lake Victoria Fisheries. IUCN, Nairobi.

JETRO (2003). Food Sanitation Law in Japan. Japan External Trade Organization, Tokyo.

Jha, V. (2002). Strengthening Developing Countries' Capacities to respond to Health, sanitary and Environmental Regulations. UNCTAD, Geneva.

Landell Mills (2001). Strengthening of Implementation Capacity in Relation to safety and Sanitary Controls of Fish and Fishery Products. Landell Mills, Trowbridge.

LVFO (2000). Frame Survey March 2000. Lake Victoria Fisheries Organisation, Jinja.

LVFRP (1999a). Marketing Study. Lake Victoria Fisheries Research Project, Kisumu.

LVFRP (1999b). The Survey of Lake Victoria's Fishers. Lake Victoria Fisheries Research Project, Kisumu.

McCormick, D. and Mitullah, W.V. (2002). Institutional Response to Global Perch Markets: The Case of Lake Victoria Fish Cluster. Paper presented at the conference Local Agri-Food Systems: products, Enterprises and Local Dynamics, Montpellier.

Medard, M. and Wilson, D.C. (1998). Changing Economic Problems for Women in the Nile Perch Fishing Communities of Lake Victoria. Anthropologica, $\underline{38}$, 149-172. 
Ministry of Health (1998a). Fishery Products Exports and Progress Report on the Status of the Competent Authority and the Establishments. Ministry of Health, Nairobi.

Ministry of Health (1998b). Corrective Actions by the Competent Authority and Comments on Shortcomings Observed by FVO Mission to Kenya on Pesticide Residues Coming from Lake Victoria Carried Out Between 16 and 18 August 1999.. Ministry of Health, Nairobi.

Mkisi, M. (1991). Fisheries Socio-economic Surveys for the Tanzanian Side of Lake Victoria. Paper presented at the Symposium of Socio-Economic Aspects of Lake Victoria Fisheries, Bujumbura.

Mitullah, W.V. (1998). Fishing and Fish Processing Cluster at Lake Victoria, Kenya. PhD Thesis, University of Sussex.

Mitullah, W.V. (1999). Lake Victoria's Nile Perch Fish Cluster: Institutions, Politics and Joint Action. IDS Working Paper 87. Institute of Development Studies, Brighton.

Mortimore, S. and Wallace, C. (2000). HACCP - A Practical Approach. Chapman and Hall. London.

Musonda, F.M. and Mbowe, W. (2001). The Impact of Implementing SPS and TBT Agreements: The Case of Fish Exports to European Union by Tanzania. CUTS, Jaipur.

Mussa, C., Vossenaar, R. and Waniala, N. (2002). Strengthening Developing Countries' Capacities to Respond to Health, Sanitary and Environmental Requirements. UNCTAD, Geneva.

Namisi. P.W. (2000). Socio-Economic Implications of the Fish Export Trade on the Fishers and Fisheries of Lake Victoria in Uganda. Lake Victoria Fisheries Research Project.

NEJLV (2002). Cross-Border Fishing and Fish Trade on Lake Victoria. Network of Environmental Journalists for Lake Victoria,

Ong'ang'a, O. (2002). Poverty and Wealth of Fisherfolks in the Lake Victoria Basin of Kenya. OSIENALA, Kisumu.

Othina, A.N. abd Osewe-Odera, S. 91996). Catch and Effort Awareness Survey for Artisanal Fisheries of Lake Victoria (Kenya Waters). Kenya Marine and Fisheries Research Institute, Kisumu.

Owino, J.P. (1999). Traditional and Central Management Systems of the Lake Victoria Fisheries in Kenya. IUCN, Nairobi. 
Rahman, M. (2001). EU Ban on Shrimp Imports from Bangladesh: A Case Study on Market Access Problems Faced by the LDCs. CUTS, Jaipur.

Reardon, T. and Berdegue, J.A. (2002). The Rapid Rise of Supermarkets in Latin America: Challenges and Opportunities for Development. Development Policy Review, 20 (4), 371-387.

Reynolds, J.E. and Greboval, D.F. (1988). Socio-Economic Effects of the Evolution of Nile Perch Fisheries in Lake Victoria: A Review. Committee for the Inland Fisheries of Africa, FAO, Rome.

Reynolds, J.E., Greboval, D.F. and Mannini, P. (1995). Thirty Years on: The Development of the Nile Perch Fishery in Lake Victoria. In: Pitcher, T.J. and Hart, P.J.B. (eds). The Impact of Species Change in African Lakes. Chapman and Hall, London.

SMEC (2002). A Study Leading to the Establishment of a Fish Levy Trust. Unpublished document.

UNDP (2002). Human Development Report 2001: Kenya. United Nations Development Program, Nairobi.

UNEP (2001a). Country Case Studies on Trade and the Environment: A Case Study of Bangladesh's Shrimp Farming Industry. UNEP, Geneva.

UNEP (2001b). Country Case Studies on Trade and the Environment: A Case Study on Uganda's Fisheries Sector. UNEP, Geneva.

Visser, W. (2003). Fresh Nile Perch Chain Kenya-EU. Department of Product Development and Quality Control, Wageningen University.

Wakwabi, E., Abila, R. and Mbithi, M. (2003). Kenya Fisheries Sub-Sector Diagnostic Report. Department of Fisheries, Nairobi.;Kenya Fish Processors and Exporters Association, Nairobi; Export Promotion Council, Nairobi.

Weatherspoon, D. and T. Reardon (2003). The Rise of Supermarkets in Africa: Implications for Agrifood Systems and the Rural Poor. Development Policy Review, 21(3): 333-355.

World Bank (1996). Lake Victoria Environmental Management Project: Kenya, Tanzania and Uganda. World Bank, Washington DC.

WTO (1998a). Trade Restrictions in Response to Cholera. Submission by the World Health Organization (G/SPS/GEN/53). World Trade Organization, Geneva.

WTO (1998b). Summary of the Meeting Held on 12-13 March 1998. Note by the Secretariat (G/SPS/R/10). World Trade Organization, Geneva

WTO (2002). A Practical Example of Implementation of the Principle of Equivalence. Submission by the European Communities (G/SPS/GEN/304). World Trade Organization, Geneva. 
Zaramba, S. (2002). Uganda Country Report on the Integration of Multiple Sources of Technical Assistance to Capacity Building on improving the Quality of Fish for Export. FAO, Rome. 
ANNEX I: EXPORTS OF FISH AND FISHERY PRODUCTS, 2000

\begin{tabular}{|l|c|c|}
\hline \multicolumn{1}{|c|}{ Commodity } & $\begin{array}{c}\text { Volume } \\
\text { (Tonnes) }\end{array}$ & $\begin{array}{c}\text { Value } \\
\text { (US\$000) }\end{array}$ \\
\hline Nile perch fillets, frozen & 15,438 & 34,189 \\
\hline Other crustaceans, fresh, chilled or boiled in water & 336 & 923 \\
\hline Other marine fish, frozen & 398 & 755 \\
\hline Other cephalopods, frozen & 160 & 592 \\
\hline Other fish, dried, unsalted & 79 & 524 \\
\hline Fish meat, whether or not minced, frozen & 35 & 375 \\
\hline Other fish live & 129 & 345 \\
\hline Other fish, salted & 57 & 311 \\
\hline Shrimps and prawns, frozen & 55 & 250 \\
\hline Other marine fish fillets, fresh or chilled & 51 & 219 \\
\hline Other crustaceans, frozen & 20 & 86 \\
\hline Other cephalopods, fresh or chilled & 47 & 83 \\
\hline Other molluscs, frozen & 27 & 67 \\
\hline Other flatfish, frozen & 20 & 56 \\
\hline Other marine fish, fresh or chilled & 2 & 40 \\
\hline Other fish liver oils & 8 & 25 \\
\hline Other flatfish, fresh or chilled & 7 & 11 \\
\hline Other crustaceans, canned & 1 & 9 \\
\hline Salmonoids, frozen & 2 & 8 \\
\hline Other salmonoids, fresh or chilled & 4 & 4 \\
\hline Fish fillets, dried, salted or in brine & $\mathbf{1 6 , 8 7 8}$ & $\mathbf{3 8 , 8 7 3}$ \\
\hline TOTAL & & 1 \\
\hline
\end{tabular}

Source: FAO. 


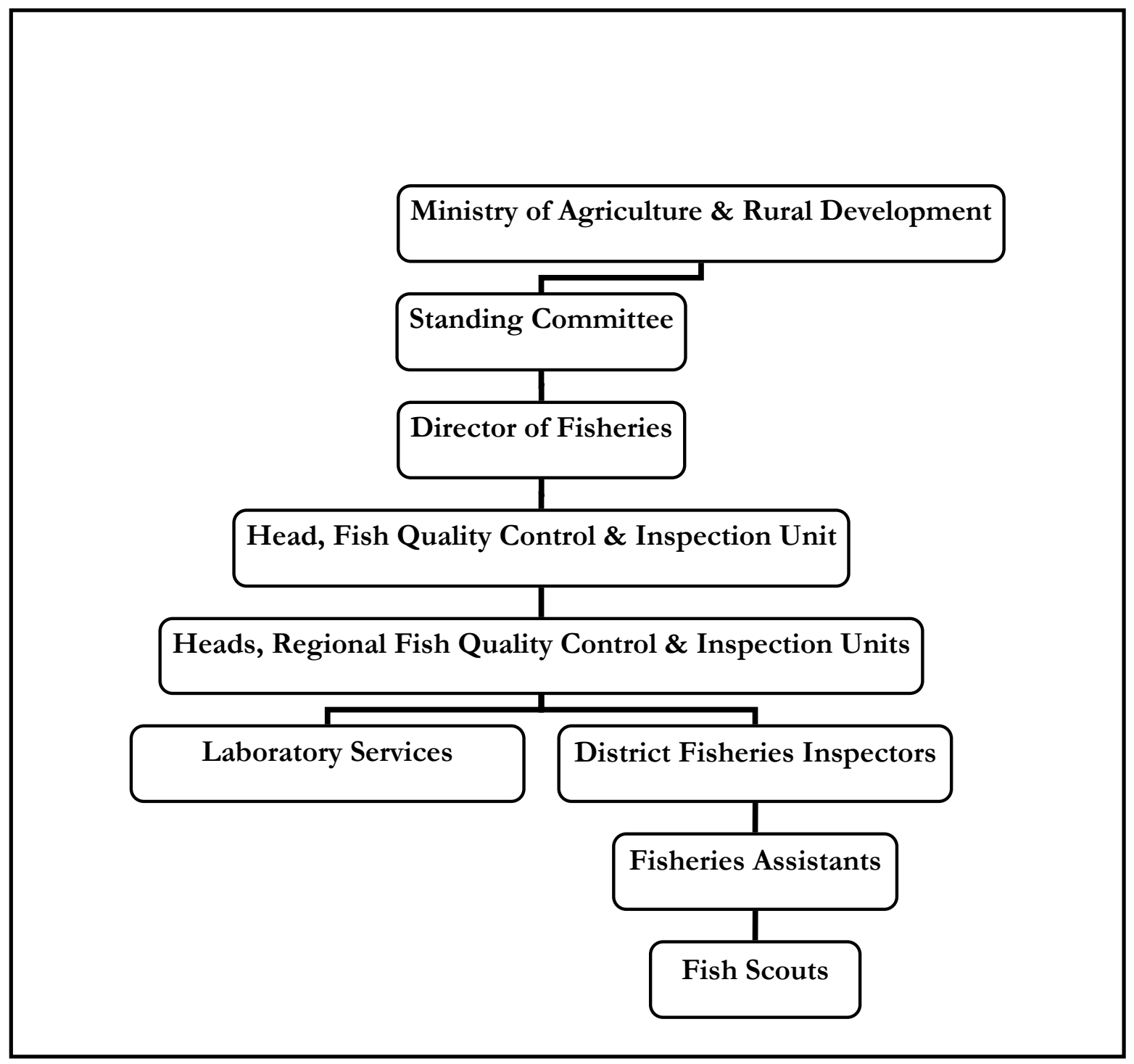

